\title{
Evaluation of Nitrate and Nitrite Destruction/Separation Technologies
}

by

D. T. Hobbs

Westinghouse Savannah River Company

Savannah River Site

Aiken, South Carolina 29808
REC EW WED

JAN 301998

OSTI

This paper was prepared in connection with work done under the above contract number with the U.S. Department of Energy. By acceptance of this paper, the publisher and/or recipient acknowledges the U. S. Government's right to retain a nonexclusive, royalty-free license in and to any copyright covering this paper, along with the right to reproduce and to authorize others to reproduce all or part of the copyrighted paper. 


\section{DISCLAIMER}

This report was prepared as an account of work sponsored by an agency of the United States Government. Neither the United States Government nor any agency thereof, nor any of their employees, makes any warranty, express or implied, or assumes any legal liability or responsibility for the accuracy, completeness, or usefulness of any information, apparatus, product, or process disclosed, or represents that its use would not infringe privately owned rights. Reference herein to any specific commercial product, process, or service by trade name, trademark, manufacturer, or otherwise does not necessarily constitute or imply its endorsement, recommendation, or favoring by the United States Government or any agency thereof. The views and opinions of authors expressed herein do not necessarily state or reflect those of the United States Government or any agency thereof.

This report has been reproduced directly from the best available copy.

Available to DOE and DOE contractors from the Office of Scientific and Technical Information, P. O. Box 62, Oak Ridge, TN 37831; prices available from (423) 576-8401.

Available to the public from the National Technical Information Service, U. S. Department of Commerce, 5285 Port Royal Road, Springfield, VA 22161. 


\section{DISCLAIMER}

Portions of this document may be illegible electronic image products. Images are produced from the best available original document. 


\title{
RECEIVED
}

JAN 301998

OSTI

\section{EVALUATION OF NITRATE AND NITRITE DESTRUCTION/SEPARATION TECHNOLOGIES}

\author{
Prepared for \\ Westinghouse Savannah River Company
}

\author{
Prepared by \\ RCS Corporation \\ 955 Colony Parkway \\ Aiken, SC 29803
}

Revision 0

August 29, 1997 
Rev. 0, 8/29/97

\section{CONTENTS}

EXECUTIVE SUMMARY $\ldots \ldots \ldots \ldots \ldots \ldots \ldots \ldots \ldots \ldots \ldots \ldots \ldots \ldots \ldots \ldots \ldots$

REQUIREMENTS FOR PRETREATMENT TECHNOLOGIES .............. 5

3.1 CHEMICAL AND RADIOLOGICAL CHARACTERISTICS OF DECONTAMINATED

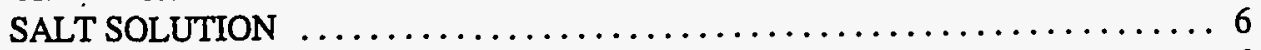

3.2 REQUIRED PROCESSING RATES $\ldots \ldots \ldots \ldots \ldots \ldots \ldots \ldots \ldots \ldots \ldots \ldots \ldots \ldots \ldots \ldots \ldots \ldots$

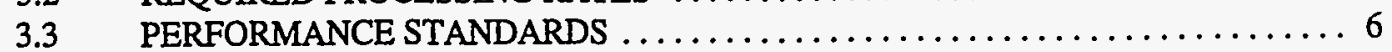

3.3.1 Nitrate / Nitrite Destruction Efficiency ................... 7

3.3.2 Worker Protection, Radiological Safety, and Process Safety Standards ..... 7

3.3.3 Environmental Protection Standards ................... 8

4.0 EXPERIENCE WITH NITRATE/NITRITE DESTRUCTION AND SEPARATION ..... 9

5.0 NITRATE AND NITRITE DESTRUCTION TECHNOLOGIES $\ldots \ldots \ldots \ldots \ldots \ldots \ldots 11$

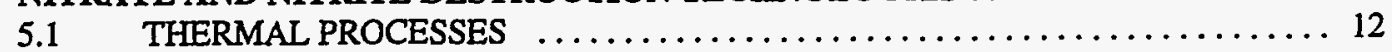

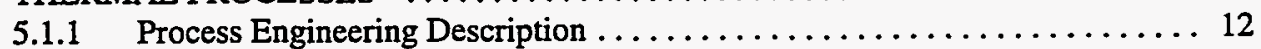

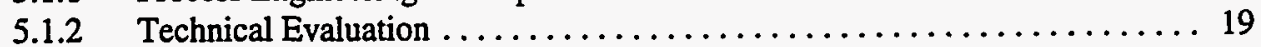

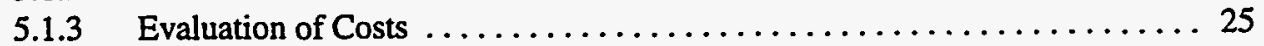

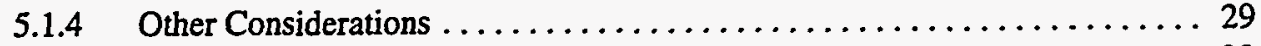

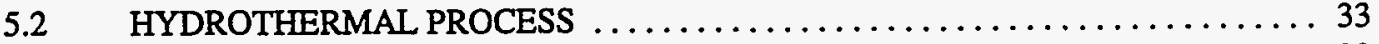

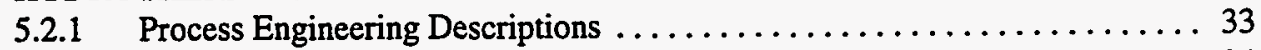

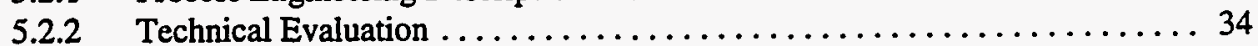

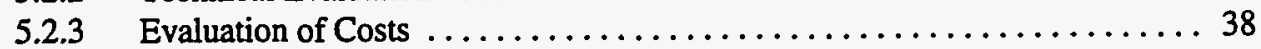

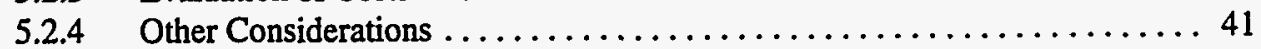

5.3 CHEMICAL REDUCTION PROCESSES $\ldots \ldots \ldots \ldots \ldots \ldots \ldots \ldots \ldots \ldots \ldots \ldots \ldots \ldots$

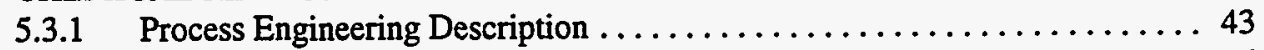

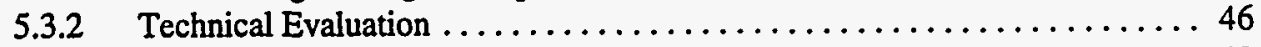

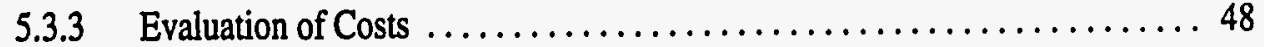

5.3 .4 Other Considerations .............................. 51

5.4 ELECTROCHEMICAL REDUCTION PROCESS $\ldots \ldots \ldots \ldots \ldots \ldots \ldots \ldots \ldots$

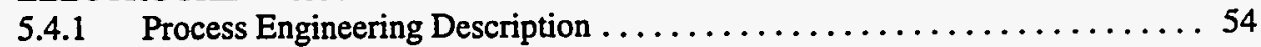

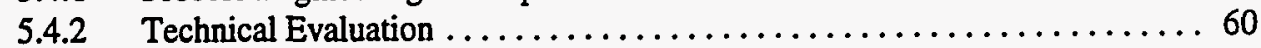

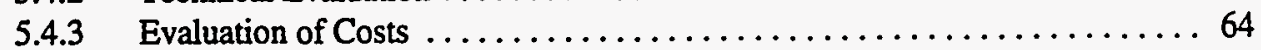

5.4.4 Other Considerations ....................................... 67

6.0 EVALUATION OF ALTERNATIVE TECHNOLOGIES FOR NITRATE AND NITRITE

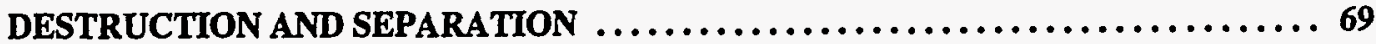

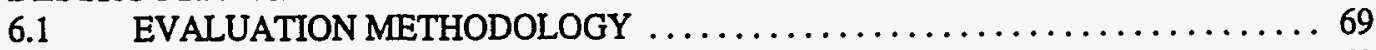

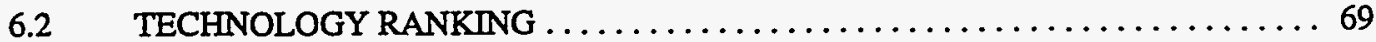

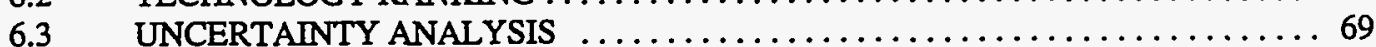

7.0 CONCLUSIONS AND RECOMMENDATIONS $\ldots \ldots \ldots \ldots \ldots \ldots \ldots \ldots \ldots \ldots \ldots$ 
Rev. 0, 8/29/97

\subsection{EXECUTIVE SUMMARY}

This report describes and evaluates four types of nitrate and nitrite destruction and separation technologies that could be used to treat the aqueous, alkaline, nitrate-bearing mixed waste that is generated by the In-Tank Precipitation (ITP) process at the Savannah River Site (SRS). The technologies considered in this report include thermal, hydrothermal, chemical, and electrochemical technologies.

During the treatment of high-level tank wastes at the SRS, the ITP process generates large quantities of an aqueous, alkaline mixed waste that contains high-levels of sodium nitrate and nitrite. This waste stream is commonly referred to as the decontaminated salt solution.

The treatment plan for the decontaminated salt solution specifies that it will be stabilized in a pozzolonic substance (Saltstone) and disposed of in engineered land disposal units (vaults) at the SRS in strict accordance with the requirements of the Environmental Protection Agency (EPA) regulations codified under 40 CFR Part 141, Part 264 Subpart N, and Part 268, as well as the Nuclear Regulatory Commission (NRC) rules codified under 10 CFR Part 61. However, the highlevels of nitrate and nitrite in the decontaminated salt solution will be leachable in the solid Saltstone matrix. The operators of the SRS are concerned that the leaching of nitrates and nitrites will threaten groundwater at the final disposal site and significantly increase costs by necessitating disposal of the Saltstone in engineered structures (i.e., vaults).

To prevent groundwater contamination at the disposal site and reduce the costs of the engineered disposal site, the U.S. Department of Energy (DOE) has determined that it will be necessary to pretreat the decontaminated salt solution to destroy or separate the nitrates and nitrites prior to stabilization in Saltstone.

DOE has authorized the operators of the SRS to develop a pretreatment system for the nitratebearing, alkaline, low-level mixed wastes. In accordance with this mission, personnel at the SRS have been actively involved in the research and development of pretreatment alternatives for several years. Based on their work to date, the researchers have tentatively determined that the electrochemical process of denitration exhibits the most favorable combination of technical and economic benefits.

In this report, the technical and economic merits of the electrochemical process are presented and compared to those of competing thermal, hydrothermal, and chemical destruction technologies. The principal findings of this report are as follows:

- All of the technologies studied would require extensive development before a full-scale process for treating the decontaminated salt solution could be constructed and operated.

- The technical and economic feasibility of the nitrate to ammonia and ceramic (NAC), vitrification, and electrochemical processes are more attractive than the other alternatives investigated. 
- More robust treatment technologies, such as plasma arc or vitrification, are more versatile that the electrochemical, hydrothermal, and NAC processes and offer the ability to treat additional waste streams.

The electrochemical reduction process has been extensively tested on SRS waste streams and is more mature in this application than the other technologies. Significant uncertainties remain in the development of all of the technologies investigated; however, the uncertainties associated with electrochemical reduction are much smaller than those associated with the other technologies.

\subsection{DEFINITION OF THE PROBLEM}

This document describes the results of an independent technical and economic feasibility study of several alternative technologies for destroying nitrates and nitrites in the decontaminated salt solution waste stream at the Savannah River Site (SRS). This waste stream is a low-level mixed waste that is one of a wide variety of nitrate- and nitrite-bearing aqueous mixed waste streams generated and stored at U.S. Department of Energy (DOE) facilities.

At the SRS, the primary source of nitrate-bearing aqueous waste is the In-Tank Precipitation (ITP) process, which is a pretreatment process for high-level tank wastes that are undergoing vitrification at the Defense Waste Processing Facility (DWPF). This nitrate-bearing waste stream, produced by the neutralization and precipitation of acidic high-level aqueous waste, is commonly referred to as the decontaminated salt solution.

The SRS stores approximately 130 million liters (34 million gallons) of high-level waste liquids. Pretreatment of this high-level waste is expected to generate approximately 92 million gallons of decontaminated salt solution over the next 20 to 25 years. ${ }^{1.2}$

All DOE sites that store and generate aqueous low-level mixed wastes have been tasked with developing treatment plans for the stabilization and disposal of the wastes. Although the treatment plans vary from site to site, common elements in each involve two sequential steps:

(1) stabilization or immobilization in a solid and

(2) disposal in a secure land-based unit (landfill or vault).

Some of the stabilization and immobilization processes being considered include stabilization in a pozzolonic matrix (cementation), immobilization in a ceramic matrix, and vitrification to a glass matrix. The SRS has tentatively elected to stabilize the nitrate wastes in a pozzolonic matrix (Saltstone) and to dispose of the stabilized solid in on-site burial vaults.

${ }^{1}$ Kapline Enterprises, Inc., "Aqueous Nitrate Waste Treatment: Technology Comparison, Cost/Benefit, and Market Analysis, DOE/OR 2013, January 1994.

2"High-level Waste Systems Plan," Revision 7 (u), HLW-OVP-96-0083, October 1996. 
The presence of nitrates and nitrites in these wastes presents several problems in the context of the stabilization processes. These include:

- Reduced compressive strength of the final waste matrix

- Increased leachability of the final waste matrix due to high nitrate solubility

- Potential for unstable reactions with organic constituents during processing

- Generation of off-gases containing oxides of nitrogen $\left(\mathrm{NO}_{\mathrm{x}}\right)$, ammonia, and hydrogen.

To effectively remedy the problems outlined above, the nitrate and nitrite in the waste must be either destroyed or separated from the liquid undergoing stabilization. Toward this objective, the operators of most DOE facilities, including the SRS, are considering some form of pretreatment to destroy or separate the nitrates and nitrites prior to the stabilization/immobilization step in the treatment process.

For several years, the Westinghouse Savannah River Company (WSRC) and other organizations have been researching treatment alternatives for the decontaminated salt solution, including biological, chemical reduction, electrochemical reduction, thermal, and hydrothermal processes. Based on this research, WSRC has tentatively elected to pretreat the decontaminated salt solution waste using electrochemical reduction to destroy the nitrates and nitrites and then solidify the remaining liquid in a special hydraulic cement (Saltstone).

WSRC would construct a new electrochemical pretreatment facility at the SRS to destroy the nitrates and nitrites and would use the existing Z-Area Saltstone Processing Facility to immobilize the pretreated wastes in a cement/fly ash/slag matrix. The Saltstone product would, in turn, be disposed of in concrete vaults at the SRS, as shown on Figure 2-1.

Currently, 34 million gallons of the high-level waste are stored at the SRS, mainly in underground tanks. In the course of pretreating the high-level waste for processing in the DWPF, the ITP process is expected to generate approximately 92 million gallons of decontaminated salt solution over the next 25 years. Consequently, the nitrate pretreatment plant to be constructed at the SRS will be required to process approximately 92 million gallons of the decontaminated salt solution waste stream during its operational life of approximately 25 years. The average processing rate will be approximately 4 million gallons per year (gpy).

Preconceptual engineering plans have been completed for a nominal 2 million gallon per year 
(gpy) industrial-scale electrochemical denitration plant at the SRS. ${ }^{3}$ This preconceptual design was completed before the current version of the SRS high-level waste systems plan was published and was, therefore, based on a smaller system capacity. Some changes to the preconceptual design that are discussed in later sections of this report will be necessary to upgrade the electrochemical denitration system to meet the requirements spelled out in the current high-level waste systems plan.

At this time, WSRC is awaiting funding from DOE to proceed with the refinement of the conceptual and detailed engineering designs for the electrochemical denitration plant.

In June 1997, the RCS Corporation of Aiken, South Carolina, was contracted by WSRC to perform an independent literature review of the state-of-the-art in nitrate waste treatment. RCS was specifically tasked to review the following denitration technologies and report on their relative technical and economic merits:

- Thermal (calcination, steam reforming, vitrification, etc.)

- Hydrothermal

- Chemical

- Electrochemical

The results of this independent review are documented in this report.

\subsection{REQUIREMENTS FOR PRETREATMENT TECHNOLOGIES}

This section discusses the performance requirements for the pretreatment technologies, including chemical and radiological characteristics of the decontaminated salt solution, processing rates, and performance standards. The primary objective of the proposed pretreatment is to change the chemical characteristics of the waste so as to increase its stability and decrease its leachability following subsequent stabilization and final disposal. With this objective in mind and the causal relationship between leachability and nitrate content understood, the most important performance criterion discussed in this section is nitrate and nitrite destruction and removal efficiency.

Technologies that cannot be shown to appreciably destroy or remove the nitrates and nitrites in the waste solution will not be considered viable, regardless of their abilities to satisfy other performance criteria.

${ }^{3}$ Bechtel Savannah River, Inc., "Preconceptual Design Study for the Salt Solution Electrochemical Denitration and Caustic Recovery Facility Phase I," WAD No. LIW2EE002, September 1996. 
Rev. 0, 8/29/97

\subsection{CHEMICAL AND RADIOLOGICAL CHARACTERISTICS OF DECONTAMINATED SALT SOLUTION}

The pretreatment technology must be capable of accepting a feed stream that is aqueous, alkaline, and high in sodium and nitrates. The decontaminated salt solution is reported to be approximately $68 \%$ water by weight. It is alkaline, having a $\mathrm{pH}$ greater than 10 . Although the waste stream has not yet been formally categorized, it will likely be considered a mixed waste bearing the EPA waste codes D002 (corrosivity) and D007 (toxic because of chromium content).

The waste contains high-levels of nitrate, nitrite, and hydroxide. The chemical composition of the waste is variable. The average composition is shown in Table $3-1 .^{4}$

\begin{tabular}{|l|l|}
\hline \multicolumn{2}{|c|}{ Table 3-1, Average Composition of Decontaminated Salt Solution } \\
\hline Salt & Concentration (Molarity) \\
\hline $\mathrm{NaNO}_{3}$ & 1.95 \\
\hline $\mathrm{NaNO}_{2}$ & 0.6 \\
\hline $\mathrm{NaOH}$ & 1.33 \\
\hline $\mathrm{NaAl}(\mathrm{OH})_{4}$ & 0.31 \\
\hline $\mathrm{Na}_{2} \mathrm{CO}_{3}$ & 0.16 \\
\hline $\mathrm{Na}_{2} \mathrm{SO}_{4}$ & 0.14 \\
\hline
\end{tabular}

Radioactive species that are present in the decontaminated salt solution include ${ }^{90}$ strontium, ${ }^{137}$ cesium, ${ }^{99}$ technetium, and ${ }^{106}$ ruthenium.

\subsection{REQUIRED PROCESSING RATES}

For the purposes of this study, it was assumed that all of the decontaminated salt solution in storage and that to be generated during the continuing life of the ITP process would be treated over a period not to exceed 25 years. As stated previously, the subject volume of waste is approximately 92 million gallons. The required processing rate is, therefore, approximately 4 million gpy.

\subsection{PERFORMANCE STANDARDS}

This section of the report describes the technical and procedural performance standards that are applicable to the proposed pretreatment system.

${ }^{4}$ E-mail from David Hobbs (Savannah River Technology Center) to Mike Navetta (RCS Corporation), June 19, 1997. 
Rev, 0, 8/29/97

\subsubsection{Nitrate / Nitrite Destruction Efficiency}

Although the decontaminated salt solution is a mixed waste falling under the purview of both the Atomic Energy Act (AEA) and the Resource Conservation and Recovery Act (RCRA), the nitrate and nitrite constituents of the waste are not specifically regulated by either the Nuclear Regulatory Commission (NRC) or the Environmental Protection Agency (EPA). Also, the South Carolina Department of Health and Environmental Control does not specifically regulate nitrate and nitrite constituents of mixed wastes. Any regulation of the nitrate or nitrite constituents is indirect, through the provisions of RCRA, dealing with reactivity of the waste matrix, and the Safe Drinking Water Act (SDWA) dealing with the protection of groundwater resources. Consequently, the environmental regulations applicable to the proposed pretreatment plant do not address nitrate or nitrite destruction efficiency.

In the case of this proposed facility, the required nitrate/nitrite destruction efficiency is determined by the waste acceptance criteria (WAC) and the performance standards for the downstream facilities (Saltstone processing and disposal vaults).

The upper tolerance limits for nitrate and nitrite documented in the WAC for the Saltstone process are 4.5 molar $(\mathrm{M})$ and $1.0 \mathrm{M}$, respectively. ${ }^{5}$ These tolerance limits are above the average levels of nitrates and nitrites found in the decontaminated salt solution. Thus, there is no logical correlation between the required nitrate/nitrite destruction efficiency and the current waste acceptance criteria for the Saltstone facility.

The required nitrate/nitrite destruction efficiency, however, is correlated with the desired long-term performance of the solidified Saltstone waste form. Nitrates are highly soluble in water, and their presence in the Saltstone poses long-term risks to the groundwater underlying the disposal site. Reductions in nitrate and nitrite concentrations are desired to ensure that nitrates do not pose an unreasonable threat to groundwater in the vicinity of the Saltstone disposal vaults. For the purposes of this study, an arbitrary minimum nitrate and nitrite destruction efficiency of $90 \%$ was established.

\subsubsection{Worker Protection, Radiological Safety, and Process Safety Standards}

The following DOE Orders prescribe that the pretreatment system be designed and operated in a manner that minimizes the potential for process accidents and radiological and nonradiological hazards to personnel:

- $\quad 5480.1 B$, Environment, Safety, and Health program for DOE Operations

${ }^{5}$ Westinghouse Savannah River Company, "WSRC 1S Waste Acceptance Criteria Manual: Procedure 4.01, Acceptance Criteria for Aqueous Waste Sent to the Z-Area Saltstone Production Facility," Rev. No. 1, May 30, 1997. 
- 5481.1B, Safety Analysis and Review System

- 6430.1, General Design Criteria Manual

These DOE Orders, in turn, reference hundreds of related codes and standards including those of the Occupational Safety and Health Administration (OSHA), the National Fire Protection Association (NFPA), the American National Standards Institute (ANSI), and other outside agencies.

\subsubsection{Environmental Protection Standards}

The applicable environmental protections standards are of three basic types: (1) groundwater protection, (2) air emissions, and (3) surface water releases. These standards are documented in the South Carolina Hazardous Waste Management Regulations, the South Carolina Air Pollution Regulations, the National Pollutant Discharge Elimination System (NPDES), the National Emission Standards for Hazardous Air Pollutants (NESHAPs), and RCRA.

The treatment system to be constructed at the SRS will probably require permits under the South Carolina hazardous waste and air pollution control regulations. However, based on recent experience at SRS with a vitrifier for mixed wastes, it may be possible to permit the treatment system by rule as a wastewater treatment unit, thereby bypassing the hazardous waste permit. This report assumes that hazardous waste and air pollution permits will be required.

The treatment system to be constructed at the SRS will be a line-item capital project and, as such, will be required to comply with the provisions of the National Environmental Policy Act (NEPA). At a minimum, an environmental assessment (EA) will be needed to address NEPA requirements. It is possible that a more rigorous environmental impact statement (EIS) could be required.

\subsubsection{Groundwater Protection}

The groundwater protection standards applicable to the proposed pretreatment system require that it be designed and operated in a manner that prevents the migration of hazardous constituents from the decontaminated salt solution into the underlying groundwater. Given that the pretreated waste will be solidified as Saltstone prior to final disposal in vaults, the groundwater protection standard also mandates that the product of pretreatment be amenable to the formulation of a stable and nonleaching Saltstone matrix.

Under the universal treatment standards of RCRA codified at 40 CFR 268.40 and 268.48, the decontaminated salt solution must be treated prior to land disposal to neutralize its corrosivity and reduce its leachability when tested using the Toxicity Characteristic Leaching Procedure (TCLP) to a level below $0.86 \mathrm{mg} / \mathrm{L}$. 
Rev. 0, 8/29/97

\subsubsection{2_Air Protection}

The proposed pretreatment plant will be subject to permitting under the Clean Air Act and will fall under the NESHAP reguiations. The air permits for the facility will be required before construction begins and will probably specify monitoring and emission limits for uranium, particulate, $\mathrm{NO}_{\mathrm{x}}$, and other hazardous air pollutants.

\subsubsection{Surface Water Protection}

The applicable surface water protection standards will place limits on any releases of hazardous constituents from the pretreatment system to surface water. These limits may be implemented through the issuance of a new NPDES permit or the modification of an existing permit.

\subsection{EXPERIENCE WITH NITRATE/NITRITE DESTRUCTION AND SEPARATION}

Substantial research and development (R\&D) into chemical, electrochemical, thermal, and hydrothermal processes has been conducted at various DOE facilities and universities over the past 15 years. With the exceptions of the engineering-scale electrochemical cells at the SRS and the New Waste Calcining Facility (NWCF) at the Idaho National Engineering Laboratory (INEL), this research has been restricted to the bench- and pilot-scale studies. Some research and engineeringscale operations have occurred in Europe and Japan. This domestic and international experience is summarized below.

\section{Chemical Reduction}

Domestic and international experience with chemical reduction technologies in treating radioactive aqueous wastes is very limited. For many years in Europe and Japan, chemical reduction using organic reductants has been used to treat acidic high-level wastes. The experience in Japan and Europe has shown, however, that the chemical reduction process using organic reductants does not destroy a high percentage of the nitrate in high-level waste and does not work in alkaline solutions. ${ }^{6}$

The Oak Ridge National Laboratory (ORNL) and Florida International University have been developing variations of chemical reduction, the nitrate to ammonia and ceramic (NAC) and nitrate to ammonia and glass (NAG) chemical reduction processes, for several years. Bench-scale testing with nitrate-bearing wastes has been completed. Scale-up to a pilot plant or engineeringscale system has not yet occurred and, given DOE's increasing reliance on privatization as a solution to environmental remediation and waste management, may not occur in the foreseeable future.

6Taylor, P.A, Kurath, D.E., "Evaluation of Nitrate Destruction Methods," DOE/MWIP-10, March 30, 1993. 
Rev. 0, 8/29/97

\section{Thermal}

Calcining, one form of thermal processing, has been used to treat nitrate-bearing high-level wastes in a full-scale process at the Idaho Chemical Processing Plant (ICPP) near Idaho Falls, Idaho. The calcining process at the ICPP employs fluidized bed technology and has been used for over a decade to treat acidic low sodium wastes generated as raffinates during the reprocessing of spent nuclear fuel. This process, though well-established for these acidic low sodium wastes, will not work on the high sodium alkaline wastes at the SRS because the sodium will cause slagging and sintering in the fluidized bed.

Vitrification is another thermal process being extensively pursued throughout the DOE complex as the treatment choice for high-level tank wastes. The Defense Waste Processing Facility (DWPF) at the SRS is a full-scale vitrification system. The West Valley Demonstration Plant is another operational full-scale plant. A similar facility is planned for the Hanford site.

Under a fixed price contract, GTS Duratek has been treating low-level mixed wastes at the SRS for the past year using the largest vitrifier ever deployed into the field for radioactive application. The contract calls for GTS Duratek to treat 660,000 gallons of mixed waste for $\$ 14$ million. The first 5-metric-ton-per-day melter that GTS Duratek mobilized to the site experienced severe corrosion after one year and had to be replaced. GTS Duratek is in the process of bringing the replacement unit on-line. The melter at the SRS is the prototype for the 10-metric-ton-per-day unit that GTS Duratek intends to construct and operate at Hanford under its partnership with British Nuclear Fuels Limited (BNFL). ${ }^{7}$

Sandia National Laboratory (SNL) was involved in the development of steam reforming in the early 1990s. SNL's efforts were directed at the treatment of tank wastes at Hanford. According to SNL personnel involved in this work, the principle of the technology was demonstrated on the bench-scale. Process reliability at the pilot-scale could not be achieved, however. Due to these failures and funding shortages, SNL phased out its involvement in steam reforming several years ago. ${ }^{8}$ GTS Duratek has continued to work with steam reforming. GTS Duratek representatives stated that the technology is being used in Oak Ridge to process contaminated animal carcasses and at the Trojan nuclear plant for radioactive waste applications. GTS Duratek claims that the technology will be used to process various organics and solids at the INEL under subcontract to BNFL. ${ }^{9}$ Attempts to acquire more detailed information on the latest developments in steam reforming from cognizant GTS Duratek personnel were unsuccessful.

${ }^{7}$ Telephone communication between James M. Pope (GTS Duratek) and Mike Navetta (RCS), August 18, 1997.

${ }^{8}$ Telephone communication between Larry Bustard (Sandia National Laboratories) and Mike Navetta (RCS), July 31, 1997.

Telephone communication between Andrew Smith (GTS Duratek) and Mike Navetta (RCS), August 7,1997. 
Plasma arc technology has been researched as an alternative for treating radioactive and mixed wastes by Westinghouse, Science Applications International Corporation (SAIC), and others. Westinghouse has treated small quantities of radioactive wastes using its plasma arc system beginning in the early 1990 s. In the early and middle 1990 s, SAIC constructed and operated a pilot plant at a location in California. Presently, ATG Incorporated is building a plasma arc treatment system for mixed wastes at the Hanford site.

\section{Hydrothermal}

Los Alamos National Laboratory (LANL) has been engaged for a decade in R\&D related to the hydrothermal processing of nitrate wastes. The application of the process to the destruction of nitrates has been successfully tested on the bench-scale, but has not yet been demonstrated on the pilot-plant- or engineering-scales.

DOE sponsorship of hydrothermal research has diminished in recent years. Most of the R\&D is occurring in the private and Department of Defense (DOD) sectors. Much of the ongoing research is aimed at the treatment of chemical warfare agents, with General Atomics Corporation and Foster Wheeler leading the development of competing variations of the technology. General Atomics has an operational pilot plant that is used for treatability and other studies at its facility in San Diego, California. ${ }^{10}$

\section{Electrochemical}

Throughout the 1990s, the SRS has been heavily involved in the development of the electrochemical process. Testing at the bench-scale and pilot-scale has been completed using both surrogate and actual waste streams. An engineering-scale test facility has also been constructed and operated at the SRS.

With the exceptions of the full-scale NWCF, the operational vitrifiers at the SRS, and the electrochemical research at the SRS, the R\&D efforts described above have been limited to the bench- and pilot-scale. Full-scale plants using NAC, NAG, plasma, and hydrothermal technology have not yet been constructed and operated.

\subsection{NITRATE AND NITRITE DESTRUCTION TECHNOLOGIES}

This section presents technical descriptions of technologies that are being considered by operators of DOE facilities for the destruction of nitrates and nitrites in aqueous low-level mixed waste streams. The general categories of technologies presented are thermal, hydrothermal, chemical reduction, electrochemical reduction.

Preconceptual designs for several of the more promising technologies are also presented. To

\footnotetext{
${ }^{10}$ Telephone communication between Mike Spritzer (General Atomics) and Mike Navetta (RCS), July 30, 1997.
} 
facilitate comparisons of the preconceptual designs for the various technologies, a common design basis was established (refer to Table 5-1).

\begin{tabular}{|l|l|}
\hline \multicolumn{2}{|c|}{$\begin{array}{c}\text { Table 5-1. Preconceptual Design Basis, Denitration System } \\
\text { for Decontaminated Salt Solution at the Savannah River Plant }\end{array}$} \\
\hline Design Parameter & Design Basis \\
\hline System Availability & $70 \%$ \\
\hline System Capacity & 4 million gallons per year \\
\hline Nitrate in Feed & $4.5 \mathrm{M}$ \\
\hline Nitrite in Feed & $1.0 \mathrm{M}$ \\
\hline Nitrate/Nitrite Destruction Efficiency & $90 \%$ minimum \\
\hline Plant Operating Life & 25 years \\
\hline
\end{tabular}

\subsection{THERMAL PROCESSES}

This section of the report discusses the technical and economic aspects of several thermal processes for denitrating aqueous low-level alkaline mixed waste streams.

\subsubsection{Process Engineering Description}

The basic stoichiometry of the thermal destruction of nitrates and nitrites is described in Section 5.1.1.1. Descriptions of preconceptual designs for several thermal systems for the SRS decontaminated salt solution waste stream are presented in Section 5.1.1.2.

\subsubsection{Basic Process Chemistry}

The thermal process of denitration involves the thermal decomposition of the nitrate and nitrite in the waste solution to nitrogen and oxides of nitrogen. The principal thermal decomposition reactions (stoichiometrically unbalanced) for sodium nitrate and sodium nitrite are as follows:

$$
\begin{aligned}
& \mathrm{NaNO}_{3}+\text { heat } \Longrightarrow \mathrm{N}_{2}+\mathrm{NO}_{x}+\mathrm{Na}_{2} \mathrm{O} \text { (Equation 1) } \\
& \mathrm{NaNO}_{2}+\text { heat } \Longrightarrow \mathrm{N}_{2}+\mathrm{NO}_{x}+\mathrm{Na}_{2} \mathrm{O} \text { (Equation 2) }
\end{aligned}
$$

The relative amounts of nitrogen and $\mathrm{NO}_{x}$ that are formed are largely dependent on the treatment temperature. Sodium nitrate decomposes to nitrogen, $\mathrm{NO}_{x}$, and sodium oxide in the range of 600 to $900^{\circ} \mathrm{C}$. Calciners that generally operate below $900^{\circ} \mathrm{C}$, therefore, tend to produce large amounts of $\mathrm{NO}_{x}$. Conversely, plasma furnaces that operate above $2000^{\circ} \mathrm{C}$ produce little $\mathrm{NO}_{\mathrm{x}}$. 
Rev. 0, 8/29/97

\subsubsection{SRS-Specific Configuration}

Four types of thermal processors were investigated for adaptability to the treatment of the SRS decontaminated salt solution. These are fluidized bed calciner, plasma furnace, steam reforming, and vitrification.

Preconceptual designs for full-scale processes for thermally treating the decontaminated salt solution at the SRS have not been prepared. To assess the merits of each of the thermal technologies discussed above, RCS developed preconceptual flowsheets and performed crude equipment sizing. The RCS conceptual process descriptions and flowsheets for plants employing calciner, plasma furnace, steam reforming, and vitrification technologies are as follows.

\section{Fluidized Bed Calciner}

The preconceptual design discussed below is patterned after the design of the New Waste Calcining Facility (NWCF). The NWCF is an operational calciner for high-level mixed wastes located at the ICPP.

The primary components of a fluidized bed calciner system for low-level SRS mixed waste would be two feed holding tanks, the calciner vessel, the fluidizing system, and the off-gas treatment system. The process flowsheet would be as illustrated in Figure 5-1. It is estimated that an enclosed structure with approximately 40,000 square feet of floor space would be needed to house the calciner system.

In the fluidized bed calciner system, the decontaminated salt solution would be received from the ITP process and stored in two feed tanks. Blending would occur as necessary to prepare a relatively homogeneous waste feed stream for the calciner.

From these tanks, the decontaminated salt solution would be pumped into the bed section of the fluidized bed calciner vessel. The bed section would be a suspension of fine uniform particles, possibly dolomite or a similar substance, that would be fluidized by a stream of heated air (600 to $900^{\circ} \mathrm{C}$ ). As the waste solution enters the calciner vessel, the liquid would flash into a vapor and the nitrates and nitrites would decompose to nitrous oxide and nitrogen. Water vapor, nitrous oxide, and nitrogen would exit the vessel in the off-gas stream. Metals and radionuclides would preferentially partition to the bed material.

The off-gas would flow from the calciner vessel to a cyclone or other gas-solid separator where entrained bed material would be separated from the process off-gases. The process off-gases would then flow to a wet air pollution control system for $\mathrm{NO}_{x}$ abatement prior to discharge to the atmosphere.

Periodically, excess solids would be withdrawn from the calciner vessel and transferred to the calcined solids storage bins pending incorporation into the final waste form, which, at the SRS, would probably be Saltstone. Solids captured in the cyclone would be managed in the same manner. 


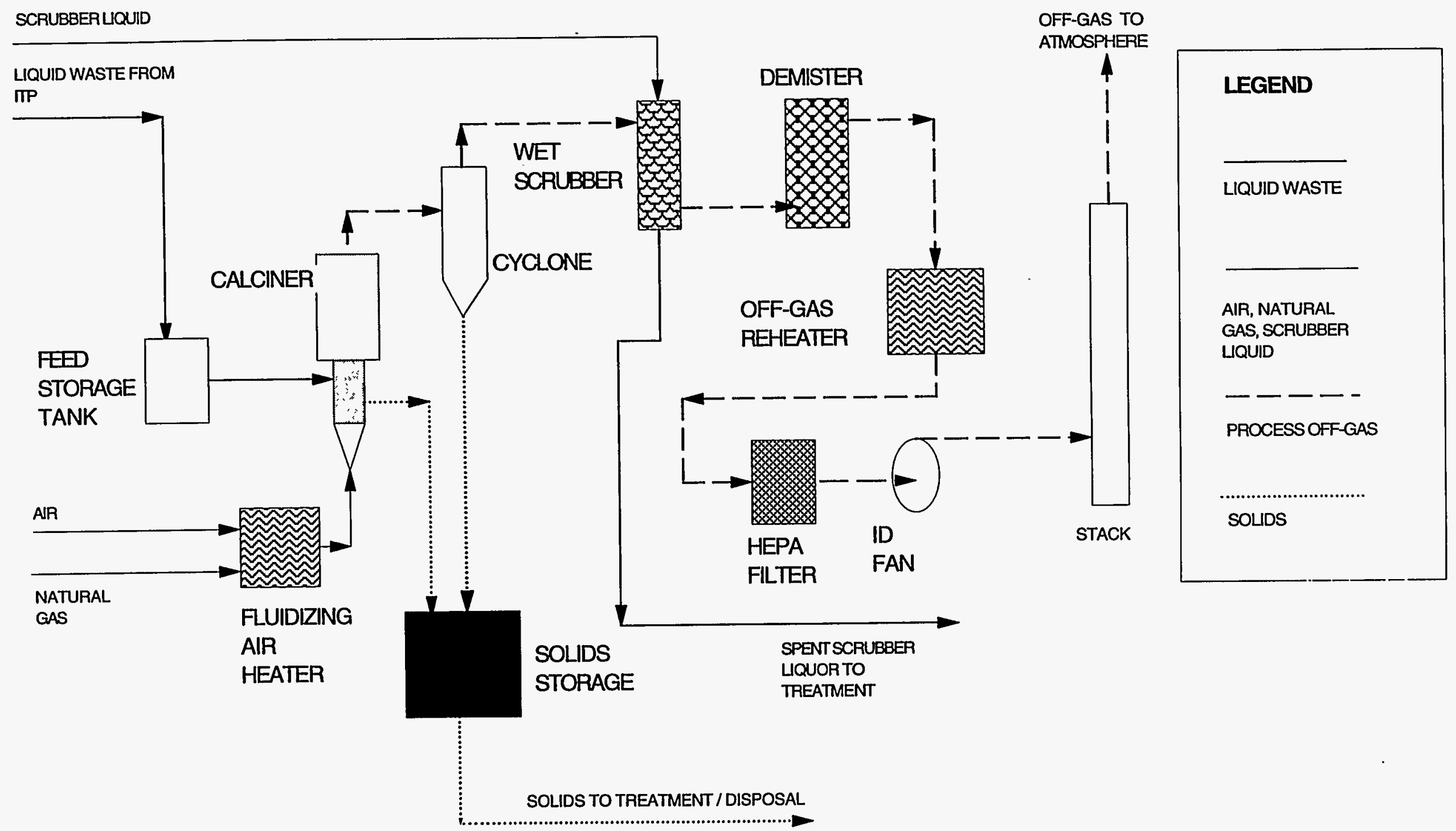

FIGURE 5-1. FLUIDIZED BED CALCINER PROCESS FLOWSHEET 
Rev. 0, 8/29/97

The solids that would be removed from the calciner would be a mixture of granular and powdery fine calcium salt and metal oxide materials with diameters less than 0.2 microns and a bulk density around $1.4 \mathrm{~g} / \mathrm{cm}^{3} .^{11}$ The solids should be readily amenable to further processing into a stable, nonleaching solid via the Saltstone, vitrifier, or other process.

\section{Plasma Furnace}

Plasma furnaces of many different configurations are being proposed for treating mixed wastes. Westinghouse has conducted testing on DOE mixed wastes with its prototype Marc 3 plasma arc furnace beginning in the early 1990s. A full-scale plasma arc system that is proposed to be constructed by ATG Incorporated near the Hanford site is currently undergoing RCRA permitting. The ATG system will be used to treat liquid and solid mixed wastes.

SAIC has constructed and operated a pilot plant based on its proprietary plasma hearth process (PHP) at a location in California as part of DOE's Technology Deployment Initiative. Proof-ofprinciple testing on this system has shown it to be capable of processing a wide range of heterogeneous solids (paper, wood, metal, etc.), low heating-value metals and glasses, high watercontent inorganic sludges, high heat-value plastics (polyethylene, polyvinyl chloride, polypropylene, etc.), high chloride wastes (trichloroethane and others), and organic sludges.

The preconceptual design envisioned by RCS is an adaptation of SAIC's PHP. ${ }^{12}$ The basic flowsheet is provided as Figure 5-2. The major equipment in the preconceptual design includes two agitated waste feed storage tanks, the plasma chamber, the plasma torch, the secondary chamber, and the air pollution control system. An enclosed structure with approximately 60,000 square feet would be needed to house the plasma process.

In the preconceptual design prepared by RCS, the waste feed would be pumped from the holding tanks and injected into the plasma chamber where it would be processed under slightly substoichiometric conditions at temperatures between 1200 and $1400{ }^{\circ} \mathrm{C}$. The inorganic material in the waste would melt at these temperatures and be collected in the fixed hearth crucible where it would separate into two molten phases--slag and metal. All of the process heat would be supplied by the plasma torch that would extend into the plasma chamber.

\footnotetext{
"Westinghouse Idaho Nuclear Company, Inc., "Leaching Characteristics of Idaho Chemical Processing Plant Calcines," WINCO-1074, February 1990.

${ }^{12}$ Gillins, R.L., Poling, S.D., "Latest Developments in the Plasma Hearth Process Demonstration program for Treatment of Radioactive Mixed Waste," published in the proceedings of the 1996 International Conference on Incineration and Thermal Treatment Technologies.
} 


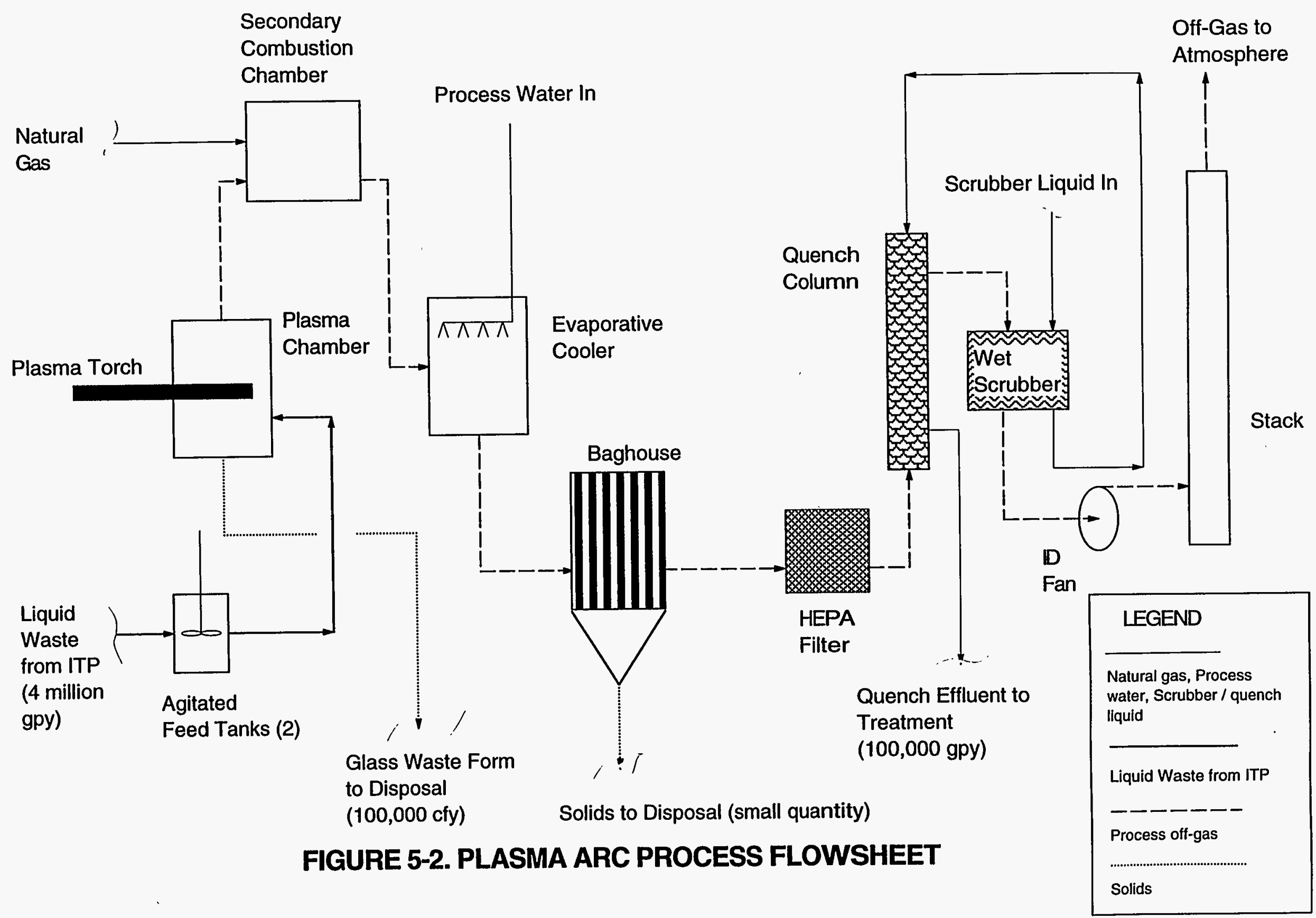


Rev. 0, 8/29/97

Actinides and oxidized metals would tend to partition to the slag phase. ${ }^{13}$ The slag and metal phases would be periodically removed from the crucible, poured into canisters, and allowed to cool and solidify to waste forms suitable for direct land disposal without further treatment.

Organics in the waste feed would be converted to carbon monoxide, carbon dioxide, and hydrogen, which would leave the plasma chamber in the off-gas. Other off-gas constituents would include nitrogen gas with traces of $\mathrm{NO}_{x} \mathrm{HCL}, \mathrm{H}_{2} \mathrm{~S}$, and methane.

The off-gas would be ducted to a gas-fired excess air chamber, where it would be retained at temperatures above $1000^{\circ} \mathrm{C}$ for 2 seconds to ensure complete destruction of organic constituents. After leaving the secondary chamber, the off-gas would be processed through a water quench and wet scrubber system for particulate and $\mathrm{NO}_{\mathrm{x}}$ control before release to the atmosphere. The wet scrubber would produce a liquid waste stream requiring treatment prior to disposal. This waste stream would be processed at the SRS Effluent Treatment Facility.

\section{Steam Reforming}

SNL and Synthetica Technologies investigated the use of steam reforming for the destruction of organics and nitrates in liquid mixed wastes for several years in the early 1990s. Since then, GTS Duratek has acquired the rights to the technology and has used it for radioactive waste applications at the ORNL and the Trojan nuclear plant. The principal components of a steam reforming system for decontaminated salt solution would include two feed tanks, an evaporator, a detoxifier reactor, and an air pollution control system. The process flowsheet would be as provided on Figure 5-3.

In the steam reforming process, the waste would be pumped from the feed storage tanks to the evaporator. In the evaporator, the waste would be contacted with live steam and evaporated at a temperature of approximately $300{ }^{\circ} \mathrm{C}$ under a slight vacuum.

The vaporized waste would then flow to the electrically heated detoxifier reactor, where it would be heated to approximately $1200^{\circ} \mathrm{C}$ and retained for at least one second to affect the destruction of the nitrates and nitrites to $\mathrm{NO}_{\mathrm{x}}$ and nitrogen gas.

A slip stream of the off-gas from the detoxifier reactor would be pulled into the air pollution control system to maintain a mass balance in the process. The balance of the off-gas (primarily steam) would be recirculated into the evaporator.

The process should produce little or no solid secondary waste streams. The primary secondary waste stream would be the liquid blowdown from the air pollution control system. This blowdown stream would require treatment prior to disposal, probably at the SRS Effluent Treatment Facility.

${ }^{13}$ Gillins, R.L., Poling S.D., "Latest Developments in the Plasma Hearth process Demonstration Program for Treatment of Radioactive Mixed Waste," from the proceedings of the 1996 International Conference on Incineration and Thermal Treatment Technologies. 


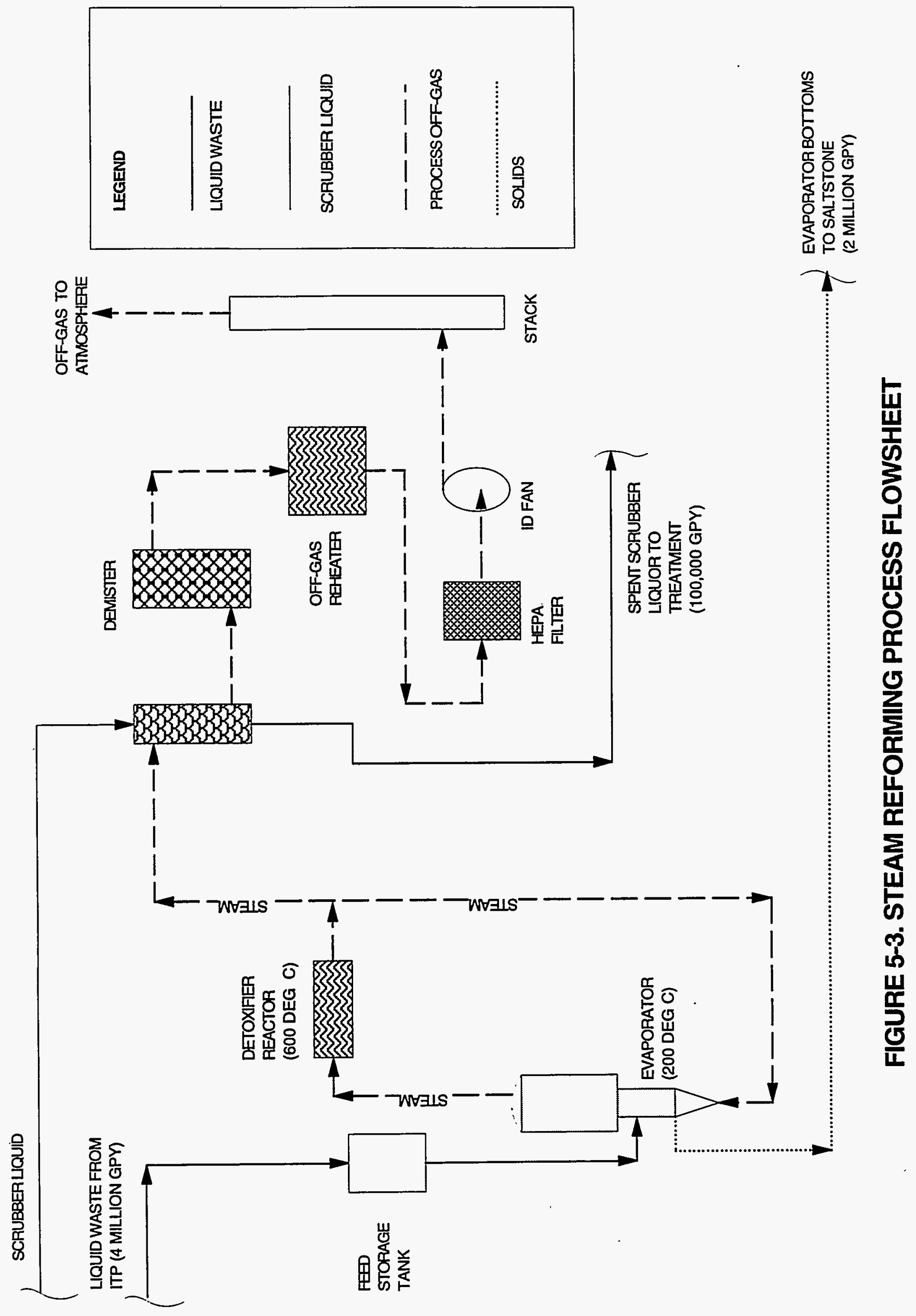


Rev. 0, 8/29/97

\section{Vitrification}

Vitrification is well-established as a treatment process for radioactive wastes. The DWPF at the SRS is an operational high-level waste vitrification system. The GTS Duratek melter at the SRS has been used to vitrify low-level mixed waste for the past year.

The basic process flow diagram envisioned by RCS for the decontaminated salt solution is provided on Figure 5-4. The primary equipment includes two feed storage tanks, the vitrifier, material handling systems, and the off-gas treatment system ${ }^{14}$. An enclosed structure with approximately 60,000 square feet would be required to house the vitrification system.

In this preconceptual design, the decontaminated salt solution would be received from the ITP and held in two tanks. From these tanks, the waste would be pumped to the vitrifier, where it would be processed at a temperatures of approximately $1200^{\circ} \mathrm{C}$ with the addition of silica and possibly urea. At these temperatures within the vitrifier the inorganics would become a molten glass or slag, organics would readily oxidize to carbon dioxide and water vapor, and nitrates and nitrites would thermally decompose to $\mathrm{NO}_{\mathrm{x}}$.

Unfortunately, the operating conditions of the vitrifier may be conducive to the oxidation of nitrogen to nitrous oxide and other forms of $\mathrm{NO}_{x}$ that would require treatment before being discharged to the atmosphere. Therefore, the process off-gas would be piped to an air pollution control system which would consist of a water quench, wet scrubber system, demisters, reheaters, and HEPA filters.

The molten slag would be decanted from the vitrifier, cooled and formed into spherical-shaped solids, and poured into drums. The glass would be a durable and nonleaching waste form that may be suitable for direct land disposal without further treatment. This waste form may be amenable to delisting under RCRA. If delisted, the waste form could be disposed of as low-level solid waste in an on-site landfill.

The wet scrubber would produce a liquid waste stream that would require treatment prior to disposal. This waste stream would be processed at the SRS Effluent Treatment Facility.

\subsubsection{Technical Evaluation}

The major advantages and disadvantages associated with the thermal technologies described in Section 5.1.1 are discussed in Sections 5.1.2.1 and 5.1.2.2, respectively. The abilities of the technologies to meet the performance standards discussed in Section 3.4 are summarized in Section 5.1.2.3. The maturity of the technology and outstanding research and development needs are discussed in Section 5.1.2.4.

${ }^{14}$ Bowman, B.W., Brandys, M.M., "Development of a Vitrification Process to Solidify Savannah River M Area Waste," presented at the April 1994 meeting of the American Ceramics Society. 


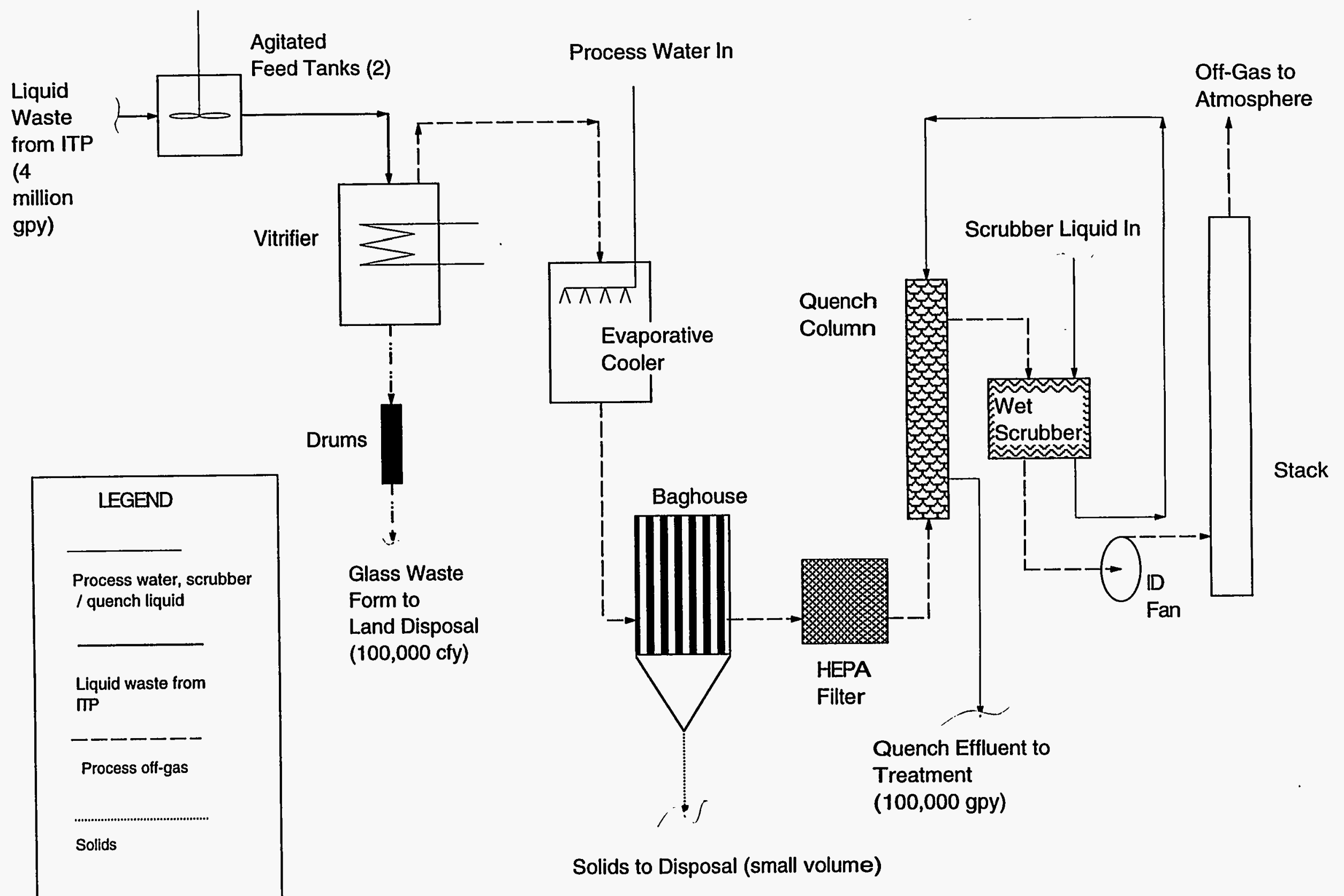

FIGURE 5-4. VITRIFICATION PROCESS FLOWSHEET 
Rev. 0, 8/29/97

\subsubsection{Major Advantages}

The major advantages associated with the thermal technologies are summarized in Table 5-2.

\section{1,2,2 Major Disadvantages}

The major disadvantages associated with these technologies are described in Table 5-3.

\begin{tabular}{|l|l|}
\hline \multicolumn{1}{|c|}{ Table 5-2. Advantages of Thermal Treatment Technologies } \\
\hline Technology & \multicolumn{1}{|c|}{ Advantages } \\
\hline Fluidized Bed Calciner & $\begin{array}{l}\text { Significant volume reductions (over 70\%) are possible. } \\
\text { Process has been proven to work at full-scale on low sodium } \\
\text { radioactive waste streams. } \\
\text { Over } 30 \text { years of operational experience with calciners at the } \\
\text { INEL. }\end{array}$ \\
\hline Plasma Arc Furnace & $\begin{array}{l}\text { Significant volume reductions (over 70\%) are possible. } \\
\text { Product slag is highly resistant to leaching, has a matrix durability } \\
\text { similar to engineered glasses, and may be suitable for disposal } \\
\text { without further treatment. } \\
\text { Nitrates are converted primarily to nitrogen gas. }\end{array}$ \\
$\begin{array}{l}\text { The performance of the system is relatively insensitive to waste } \\
\text { composition, minimizing the need to conduct extensive waste } \\
\text { characterization and segregation prior to treatment. }\end{array}$ \\
$\begin{array}{l}\text { The treatment system is versatile and can accept a wide range of } \\
\text { solid and liquid wastes. }\end{array}$ \\
\hline
\end{tabular}

${ }^{15}$ Taylor, P.A., Kurath, D.E., "Evaluation of Nitrate Destruction Methods," DOE/MWIP-10, March 30, 1993, p. 19.

${ }^{16}$ Gillins, R.L., Poling, S.D., "Plasma Hearth Waste Treatment Demonstration for Radioactive Mixed Waste," presented at the 1994 Incineration Conference, May 1994. 


\begin{tabular}{|l|l|}
\hline \multicolumn{2}{|c|}{ Table 5-2. Advantages of Thermal Treatment Technologies } \\
\hline \multicolumn{1}{|c|}{ Technology } & \multicolumn{1}{c|}{ Advantages } \\
\hline Steam Reforming & $\begin{array}{l}\text { Significant volume reductions (over 70\%) are possible. } \\
\text { The process can destroy organics in addition to nitrates and } \\
\text { nitrites. }\end{array}$ \\
\hline Vitrification & $\begin{array}{l}\text { Significant volume reductions are possible. } \\
\text { Product glass or slag may be suitable for disposal without further } \\
\text { treatment. } \\
\text { Process has been proven to work on other radioactive waste } \\
\text { streams. } \\
\text { Significant experience with vitrification systems at the SRS, } \\
\text { including the DWPF and the GTS Duratek system. } \\
\text { The treatment system is versatile and can accept a wide range of } \\
\text { solid and liquid wastes. }\end{array}$ \\
\hline
\end{tabular}

\begin{tabular}{|l|l|}
\hline \multicolumn{2}{|c|}{ Table 5-3. Disadvantages of Thermal Treatment Technologies } \\
\hline Technologies & \multicolumn{1}{|c|}{ Disadvantages } \\
\hline Fluidized Bed Calciner & $\begin{array}{l}\text { High capital and operating costs. } \\
\text { Not useful when the waste contains alkali metals, including } \\
\text { sodium. Alkali metals cause sintering of the fluidized solid } \\
\text { media. } \\
\text { Process off-gas contains high-levels of } \mathrm{NO}_{x} \text { which would } \\
\text { require treatment before release to the atmosphere. } \\
\text { The solid process residue (calcine) would require further } \\
\text { treatment prior to disposal. }\end{array}$ \\
\hline
\end{tabular}


Rev. 0, 8/29/97

\begin{tabular}{|l|l|}
\hline \multicolumn{2}{|c|}{ Table 5-3. Disadvantages of Thermal Treatment Technologies } \\
\hline Technologies & \multicolumn{1}{|c|}{ Disadvantages } \\
\hline Plasma Arc Furnace & $\begin{array}{l}\text { High capital and operating costs. } \\
\text { Requires extensive development work before a full-scale } \\
\text { plant could be built. }\end{array}$ \\
$\begin{array}{l}\text { The economic utility of the plasma arc process chiefly } \\
\text { applies to solid or sludge wastes that contain significant } \\
\text { quantities of slagging materials. }\end{array}$ \\
$\begin{array}{l}\text { St. 18 } \\
\text { The process would generate a liquid secondary waste } \\
\text { requiring treatment prior to disposal. }\end{array}$ \\
$\begin{array}{l}\text { Process off-gas contains high-levels of NO } \\
\text { require treatment before release to the atmosphere. }\end{array}$ \\
$\begin{array}{l}\text { The process would generate a liquid secondary waste } \\
\text { requiring treatment prior to disposal. }\end{array}$ \\
\hline Vitrification & $\begin{array}{l}\text { High capital and operating costs. } \\
\text { Process off-gas contains high-levels of NO } \\
\text { require treatment before release to the atmosphere. } \\
\text { The process would generate a liquid secondary waste } \\
\text { requiring treatment prior to disposal. }\end{array}$ \\
\hline
\end{tabular}

\subsubsection{Potential to Meet Performance Standards}

The applicable performance standards were previously described in Section 3.4. Given its inability to process high sodium wastes, the application of fluidized bed calciner technology to the treatment of decontaminated salt solution was not considered to be technically feasible. The fluidized bed calciner technology was, therefore, omitted from further consideration. Evaluations of the remaining technologies' abilities to satisfy these performance standards follow.

${ }^{17}$ Science Applications International Corporation, "The Plasma Hearth Process," SAIC95/1309, 1995.

${ }^{18}$ Personal Communication between Ray Geimar (SAIC) and Mike Navetta (RCS), August $11,1997$. 
Rev. 0, 8/29/97

\section{Nitrate/Nitrite Destruction and Separation Efficiency}

The plasma arc, steam reforming, and vitrification processes are capable of meeting the performance standard for nitrate and nitrite destruction. Testing of these technologies at the benchscale has shown that destruction efficiencies in excess of $99 \%$ can be achieved for nitrates and nitrites. These destruction efficiencies are greater than the performance criterion of $90 \%$.

\section{Worker Safety Standards}

The plasma arc, steam reforming, and vitrification processes do not pose inordinate dangers to workers. The potential worker hazards associated with high equipment temperatures, hazardous off-gases, and radiation can be controlled using engineering and administrative controls.

\section{Process Safety Standards}

Facilities housing plasma arc, steam reforming, and vitrification processes would be classified as low or moderate hazard. Under DOE Orders 5480.5 and $5481.1 \mathrm{~B}$, detailed safety analysis reports would be required before start-up.

Nothing in the published testing history of these three technologies suggests that the process hazards cannot be effectively controlled with appropriate design features and operating procedures. On the contrary, the experience with vitrifiers at the SRS supports the conclusion that a thermal process using plasma arc, steam reforming, or vitrification technologies can be constructed and operated to meet or exceed all applicable process safety standards.

\section{Radiological Safety Standards}

The only full-scale mixed waste treatment system for nitrate-containing mixed wastes are the calciner at the ICPP, the DWPF at the SRS, and the Duratek vitrifier at the SRS. The calciner and the DWPF process high-level aqueous wastes and routinely operate within the limits of applicable radiological safety standards. The Duratek vitrifier processes low-level mixed wastes and has been shown to comply with all applicable radiological safety standards.

Given that the decontaminated salt solution contains much lower levels of radionuclides than the ICPP or DWPF waste feeds and.comparable levels to the Duratek waste feed, it is reasonable to conclude that a thermal process based on plasma arc, steam reforming, or vitrification technology can be designed and operated to meet all applicable radiological safety standards, including aslow-as-reasonably-achievable (ALARA) considerations. Shielding may be required around certain process areas.

\section{Environmental Standards}

The three viable thermal processes are each capable of meeting all applicable environmental standards. The products of the thermal treatment of decontaminated salt solution will be stable nonleaching solid waste forms and off-gases. It may be possible to dispose of the waste forms 
produced by plasma and vitrification systems without further treatment. The process off-gas may require treatment for particulate matter (PM), nitrous oxides, and hazardous air pollutants, but this can probably be accomplished using established technologies.

The treatment of process off-gases from all of the viable thermal technologies may produce wastewater that is not suitable for direct discharge to surface water. Such wastewater could probably be recycled into the waste feed stream. Thus, it is likely that this process will not produce wastewater requiring surface water discharge.

To comply with NEPA, it will be necessary to complete an EA for any thermal process. Given that the current socio-political climate is not favorable to thermal processing, an EIS may be required if one of these alternatives is selected for the denitration mission at SRS.

\subsubsection{Technology Maturity and Research and Development Needs}

Extensive research of the viable thermal treatment technologies has been ongoing at Los Alamos National Laboratory (LANL), INEL, and other sites for a number of years. Testing on mixed wastes that are similar to the decontaminated salt solution at the SRS has generally been limited to the bench-scale and pilot-scale. Extensive research and development work, including the construction and operation of pilot plants, would be necessary before full-scale plants using any of these technologies could be constructed and operated.

\subsubsection{Evaluation of Costs}

Section 5.1.3.1 discusses the capital costs of the electrochemical waste treatment system. Operations and maintenance (O\&M) costs are discussed in Section 5.1.3.2. Decontamination and decommissioning (D\&D) costs are estimated in Section 5.1.3.3. Life-cycle costs, computed on the basis of the capital, O\&M, and D\&D costs, are discussed in Section 5.1.3.4.

\subsubsection{Capital Cost}

Preliminary cost estimates for treatment systems capable of processing 4 million gpy of alkaline nitrate wastes are presented in Table 5-4. The estimated capital cost for these systems range from $\$ 33.3$ million (steam reforming) to $\$ 46.6$ million (plasma arc and vitrification).

\subsubsection{Operations and Maintenance}

Estimates of O\&M costs are summarized in Table 5-5. To the extent possible, these estimates were developed using historical operating data and information obtained from equipment manufacturers. Wherever such information was not available, the Delphi method of cost estimating was used.

The Delphi method, developed during the late 1940s by the Rand Corporation, is useful for 
Rev. 0, 8/29/97

\begin{tabular}{|l|l|l|l|}
\hline \multicolumn{4}{|c|}{ Table 5-4. Thermal Treatment Systems Capital Costs } \\
\hline & \multicolumn{3}{|c|}{ Technology Dollars) } \\
\cline { 2 - 4 } & Plasma Arc & $\begin{array}{l}\text { Steam } \\
\text { Reforming }\end{array}$ & Vitrification \\
\hline Plant Component & 170,000 & 170,000 & 170,000 \\
\hline Storage Vessels & & $1,650,000^{\mathrm{b}}$ & $5,000,000$ \\
\hline Primary Process Chamber & $3,500,000$ & $3,250,000^{\mathrm{c}}$ & N/A \\
\hline Secondary Process Chamber & $1,500,000$ & $2,000,000^{\mathrm{c}}$ & $2,500,000^{\mathrm{d}}$ \\
\hline $\begin{array}{l}\text { Off-Gas Treatment System (quench, } \\
\text { wet scrubber, demister, reheater, } \\
\text { HEPA filters) }\end{array}$ & $2,500,000^{\mathrm{d}}$ & & \\
\hline $\begin{array}{l}\text { Material Handling Systems } \\
\text { (overhead cranes, conveyors, etc.) }\end{array}$ & $2,000,000$ & 750,000 & $2,000,000$ \\
\hline Distributed Control System & $1,500,000$ & $1,500,000$ & $1,500,000$ \\
\hline Subtotal, Major Equipment & $\mathbf{1 1 , 1 7 0 , 0 0 0}$ & $\mathbf{8 , 3 2 0 , 0 0 0}$ & $\mathbf{1 1 , 1 7 0 , 0 0 0}$ \\
\hline $\begin{array}{l}\text { Miscellaneous Equipment @ 30\% } \\
\text { of Major Equipment }\end{array}$ & $3,350,000$ & $2,500,000$ & $3,350,000$ \\
\hline $\begin{array}{l}\text { Equipment Installation @ 50\% of } \\
\text { Major Equipment }\end{array}$ & $5,590,000$ & $4,160,000$ & $5,590,000$ \\
\hline Facilities @ \$200 / ft & $12,000,000$ & $8,000,000$ & $12,000,000$ \\
\hline $\begin{array}{l}\text { Subtotal, Installed Equipment } \\
\text { and Facilities }\end{array}$ & $\mathbf{3 2 , 1 1 0 , 0 0 0}$ & $\mathbf{2 2 , 9 8 0 , 0 0 0}$ & $\mathbf{3 2 , 1 1 0 , 0 0 0}$ \\
\hline Engineering @ 15\% & $4,820,000$ & $3,450,000$ & $4,820,000$ \\
\hline Management Reserve @ 30\% & $9,630,000$ & $6,890,000$ & $9,630,000$ \\
\hline TOTAL COST & $\mathbf{4 6 , 5 6 0 , 0 0 0}$ & $\mathbf{3 3 , 3 2 0 , 0 0 0}$ & $\mathbf{4 6 , 5 6 0 , 0 0 0}$ \\
\hline
\end{tabular}




\section{Table 5-4. Thermal Treatment Systems Capital Costs} (1997 Dollars)

\section{Notes:}

a Based on verbal quotations from John Wood Co., Valley Forge, PA, and Dal-Worth Fabrication, Inc., Grand Prairie, TX.

b Cost of evaporator, scaled up from cost reported by SNL in "Steam Reforming," September 18, 1994.

c Cost of detoxifier reactor, scaled up from cost reported by SNL in "Steam Reforming," September 18, 1994.

d Quench, wet scrubber, demister, reheater, HEPA filter.

e Wet scrubber, demister, reheater, HEPA filter.

\begin{tabular}{|c|c|c|c|}
\hline \multicolumn{4}{|c|}{$\begin{array}{l}\text { Table 5-5. Annual Operating and Maintenance Costs, } \\
\text { Thermal Treatment Systems }\end{array}$} \\
\hline O\&M Item & Units & Unit Cost, $\$$ & Extension, \$ \\
\hline \multicolumn{4}{|c|}{ Plasma Arc System } \\
\hline $\begin{array}{l}\text { Direct Labor, Operators (Fully } \\
\text { Burdened) }\end{array}$ & 12 & 60,000 & 720,000 \\
\hline $\begin{array}{l}\text { Direct Labor, Supervisors (Fully } \\
\text { Burdened) }\end{array}$ & 4 & 75,000 & 300,000 \\
\hline Electricity ${ }^{2} b$ & $\begin{array}{l}120 \text { million } \\
\mathrm{kWh}\end{array}$ & 0.057 & $6,840,000$ \\
\hline Other Utilities & 1 lot & 60,000 & 60,000 \\
\hline Maintenance @5\% of Capital Cost & 1 lot & $2,300,000$ & $2,300,000$ \\
\hline TOTAL COST & & & $10,220,000$ \\
\hline \multicolumn{4}{|c|}{ Steam Reforming System } \\
\hline $\begin{array}{l}\text { Direct Labor, Operators (Fully } \\
\text { Burdened) }\end{array}$ & 8 & 60,000 & 480,000 \\
\hline $\begin{array}{l}\text { Direct Labor, Supervisors (Fully } \\
\text { Burdened) }\end{array}$ & 4 & 75,000 & 300,000 \\
\hline Electricity ${ }^{b, c}$ & 21 million $\mathrm{kWh}$ & 0.057 & $1,200,000$ \\
\hline Other Utilities & 1 lot & 60,000 & 60,000 \\
\hline
\end{tabular}




\begin{tabular}{|c|c|c|c|}
\hline \multicolumn{4}{|c|}{$\begin{array}{l}\text { Table 5-5. Annual Operating and Maintenance Costs, } \\
\text { Thermal Treatment Systems }\end{array}$} \\
\hline O\&M Item & Units & Unit Cost, \$ & Extension, \$ \\
\hline Maintenance @5\% of Capital Cost & 1 lot & $1,670,000$ & $1,480,000$ \\
\hline TOTAL COST & & & $3,520,00$ \\
\hline \multicolumn{4}{|c|}{ Vitrification } \\
\hline $\begin{array}{l}\text { Direct Labor, Operators (Fully } \\
\text { Burdened) }\end{array}$ & 12 & 60,000 & 720,000 \\
\hline $\begin{array}{l}\text { Direct Labor, Supervisors (Fully } \\
\text { Burdened) }\end{array}$ & 4 & 75,000 & 300,000 \\
\hline Electricity,d & $\begin{array}{l}145.6 \text { million } \\
\mathrm{kWh}\end{array}$ & 0.057 & $8,300,000$ \\
\hline Other Utilities & 1 lot & 60,000 & 60,000 \\
\hline Maintenance @ @ \% of Capital Cost & 1 lot & $2,300,000$ & $2,300,000$ \\
\hline TOTAL COST & & & $11,680,000$ \\
\hline \multicolumn{4}{|c|}{$\begin{array}{ll}\text { Notes } & \\
\text { a } & \text { Assumes } 30 \mathrm{kWh} \text { per gallon of waste feed. } \\
\mathrm{b} & \text { Unit cost of } \$ 0.057 \text { per } \mathrm{kWh} \text {, from telephone conversation with Tony Vovides, SRS } \\
\text { c } & \text { July } 14,1997 . \\
\mathrm{d} & \text { Assumes } 5.25 \mathrm{kWh} \text { per gallon of waste feed. } \\
\text { Assumes } 36.4 \mathrm{kWh} \text { per gallon of waste feed. }\end{array}$} \\
\hline
\end{tabular}

developing forecasts of manpower and other O\&M costs in the absence of reliable work standards or historical data. The method uses an intermediary as a control center to guide the opinions of several subject experts toward convergence.

\subsubsection{Decontamination and Decommissioning Costs}

RCS estimates the D\&D costs at the end of the operational life of each of these facilities to be $\$ 500$ per square foot of process facility. The plasma arc and vitrification systems would each require 60,000 square feet of structure. The estimated $D \& D$ costs for plasma and vitrification, therefore, would be $\$ 30$ million. The steam reforming system would require 40,000 square feet of structure. The associated D\&D cost would be $\$ 20$ million.

\subsubsection{4_Life-Cycle Costs}

For the purpose of estimating the present value of the total life-cycle cost for the various thermal 
Rev. 0, 8/29/97

systems, the following assumptions were made:

- Construction, O\&M, and D\&D costs will increase uniformly at $4 \%$ per year over the study period.

- RCRA and NEPA documentation will be prepared and all associated cost incurred in Year 0 .

- Construction will begin in Year 0 , and all capital costs will be incurred in that year.

- Operations will begin in Year 1 and continue for 25 years.

- D\&D will commence immediately following the 25-year service life and be completed in a 3-year period. D\&D costs will be uniformly distributed over this 3-year period.

- The time value of money is $8 \%$.

- Process residuals from the steam reforming system will be stabilized in Saltstone and disposed of in on-site vaults at a unit cost of $\$ 4.86$ per gallon. ${ }^{19}$

- Process residuals from the vitrification and plasma systems will be delisted and disposed of as low-level radioactive waste at a unit cost of $\$ 52$ per cubic foot. ${ }^{20}$

Given the above assumptions, the present values of the life-cycle costs range from $\$ 289$ million for the plasma arc technology to $\$ 312$ million for the vitrification technology, as listed in Table 5-6.

\subsubsection{Other Considerations}

Several other considerations impact the viability of the thermal technologies. These include the implementation schedule, secondary waste streams, pollution prevention, public acceptance, regulatory permitting, and versatility. Each is discussed in the ensuing sections of this report.

${ }^{19}$ Telephone conversation between A. Whittenburg (WSRC) and Mike Navetta (RCS), August 26, 1997.

${ }^{20}$ Telephone conversation between James Blankenhorn (SRS) and Mike Navetta (RCS), August 28, 1997. 


\begin{tabular}{|c|c|c|}
\hline \multicolumn{3}{|c|}{ Table 5-6. Present Value, Thermal Treatment Systems Life-Cycle Cost } \\
\hline Cost Item & Cost, $\$$ & Present Value, \$ \\
\hline \multicolumn{3}{|c|}{ Plasma Arc System } \\
\hline Capital Cost & $46,560,000$ & $46,560,000$ \\
\hline RCRA Permits and Tests & $1,500,000$ & $1,500,000$ \\
\hline NEPA Documentation & 100,000 & 100,000 \\
\hline \multicolumn{3}{|l|}{ O\&M Cost } \\
\hline Year 1 & $10,220,000$ & \\
\hline Total, Years 1-25 & $425,620,000$ & $156,040,000$ \\
\hline \multicolumn{3}{|l|}{ 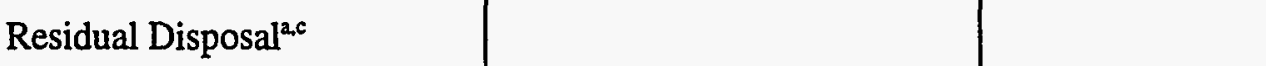 } \\
\hline Year 1 & $5,325,000$ & \\
\hline Total, Years 1-25 & $221,765,000$ & $81,303,000$ \\
\hline $\mathrm{D} \& \mathrm{D}$ Cost & $30,000,000$ & $3,760,000$ \\
\hline TOTAL COST & $725,545,000$ & $289,263,000$ \\
\hline \multicolumn{3}{|c|}{ Steam Reforming System } \\
\hline Capital Cost & $29,670,000$ & $29,670,000$ \\
\hline RCRA Permits and Tests & 500,000 & 500,000 \\
\hline NEPA Documentation & 100,000 & 100,000 \\
\hline \multicolumn{3}{|l|}{ O\&M Cost } \\
\hline Year 1 & $3,520,000$ & \\
\hline Total, Years 1-20 & $146,590,000$ & $53,740,000$ \\
\hline \multicolumn{3}{|l|}{ Residual Disposal ${ }^{b, c}$} \\
\hline Year 1 & $13,976,000$ & \\
\hline Total, Years 1-25 & $582,043,000$ & $213,388,000$ \\
\hline D\&D Cost & $20,000,000$ & $2,510,000$ \\
\hline TOTAL COST & $\mathbf{7 7 8 , 9 0 3 , 0 0 0}$ & $299,908,000$ \\
\hline
\end{tabular}


Rev. 0, 8/29/97

\begin{tabular}{|c|c|c|}
\hline \multicolumn{3}{|c|}{ Table 5-6. Present Value, Thermal Treatment Systems Life-Cycle Costs } \\
\hline Cost Item & Cost, \$ & Present Value, \$ \\
\hline \multicolumn{3}{|c|}{ Vitrification System } \\
\hline Capital Cost & $46,560,000$ & $46,560,000$ \\
\hline RCRA Permits and Tests & $1,500,000$ & $1,500,000$ \\
\hline NEPA Documentation & 100,000 & 100,000 \\
\hline \multicolumn{3}{|l|}{ O\&M Cost } \\
\hline Year 1 & $11,680,000$ & \\
\hline Total, Years 1-20 & $486,420,000$ & $178,330,000$ \\
\hline \multicolumn{3}{|l|}{ Residual Disposal ${ }^{\mathrm{ac}}$} \\
\hline Year 1 & $5,325,000$ & \\
\hline Total, Years 1-25 & $221,764,000$ & $81,303,000$ \\
\hline$D \& D$ Cost & $30,000,000$ & $3,760,000$ \\
\hline TOTAL COST & $786,344,000$ & $311,553,000$ \\
\hline \multicolumn{3}{|c|}{$\begin{array}{l}\text { Notes } \\
\text { Assumes } 70 \% \text { overall volume reduction and disposal of residue as low-level waste at } 52 \\
\text { per cubic foot. } \\
\text { Assumes } 30 \% \text { overall volume reduction and disposal of residue in Saltstone at unit cost } \\
\text { of } \$ 4.86 \text { per gallon. } \\
\text { Assumes wet scrubber blowdown is disposed at SRS Effluent Treatment Facility at a } \\
\text { unit cost of } \$ 1.25 \text { per gallon. }\end{array}$} \\
\hline
\end{tabular}

\subsubsection{Imolementation Schedule}

The requirement to denitrate the alkaline wastes is short-term. To be viable for this application, the technology should be capable of (1) being implemented in a reasonably short period of time (i.e., less than 5 years) and (2) eliminating the anticipated inventory of 92 million gallons of alkaline waste at the SRS in 25 years or less.

RCS believes that full-scale thermal processes based on any of the three viable technologies cannot be made operational in less than 5 years if traditional DOE technology development and procurement methods are used. Approximately 4 years would be needed to design, permit, construct, and operate the pilot plants that will be needed to develop scaling factors and other design parameters for the full-scale systems. Thereafter, the full-scale systems could be designed, permitted, and constructed in 4 to 5 additional years. None of the technologies are capable of 
being implemented at full-scale using DOE's traditional technology development and procurement approaches within 5 years.

However, the recent experience with the GTS Duratek vitrification contract at SRS indicates that a procurement approach based on privatization may be capable of bringing thermal technologies online in less than 5 years. In the GTS Duratek case, a vendor forum was conducted by DOE and WSRC in the Spring of 1994. Based on a proposal submitted by GTS Duratek as a follow-up to the vendor forum, DOE awarded the contract to GTS Duratek in November 1994. GTS Durtaek mobilized to the field in March 1995. The vitrification was operational on radioactive feed in October 1996. The elapsed time from the contract award to full-scale field operations was less than 24 months.

\section{1,4,2 Secondary Waste Streams}

All three of the thermal processes produce relatively large amounts of secondary waste streams. The process off-gases could contain significant amounts of $\mathrm{NO}_{x}$. These gases would require treatment prior to atmospheric discharge, probably in some sort of wet scrubber system, which, in turn, would generate a wastewater requiring treatment prior to disposal.

\subsubsection{Pollution Prevention}

It is conceivable that greater than $70 \%$ reductions in the volume of mixed waste requiring land disposal can be realized using any of the thermal processes. This volume reduction will obviously result in substantial savings in disposal costs and will be very attractive from a pollution prevention standpoint.

\subsubsection{Public Acceptance}

Non-incineration thermal processes generally receive much less publicity and public opposition than their incineration counterparts. Within the DOE community, for example, vitrification programs at radioactive waste sites have been virtually unopposed. The RCRA permitting of the plasma arc system at the ATG facility in Hanford has thus far been received favorably by the local population. There was little public opposition to the GTS Duratek vitrification project at SRS. There is generally no significant organized opposition to non-incineration thermal technologies.

\subsubsection{Requlatory Permitting}

All of the thermal processes will require a RCRA Part B permit and an air pollution permit from the South Carolina Department of Health and Environmental Control (SCDHEC). These permits will be similar in complexity to those acquired by DOE for the Consolidated Incineration Facility (CIF) at the SRS. RCS believes that the permitting process could require upwards of 24 months to complete. DOE should expect to be required by SCDHEC to complete a trial burn or similar demonstration test, if any type of thermal treatment system is constructed and operated. 
Rev. 0, 8/29/97

\section{$\mathbf{5 . 1 , 4 , 6 \quad V e r s a t i l i t y ~}$}

The thermal processes described in this section of the report are very robust and, with only minor modifications, could be used to treat a variety of radioactive, mixed, and hazardous waste generated at the SRS.

\subsection{HYDROTHERMAL PROCESS}

This section of the report discusses the technical and economic aspects of the hydrothermal process for denitrating aqueous low-level alkaline mixed waste streams.

\subsubsection{Process Engineering Descriptions}

The basic stoichiometry of the hydrothermal destruction of nitrates and nitrites is described in Section 5.2.1.1. A description of a preconceptual design for a hydrothermal system for the SRS decontaminated salt solution waste stream is presented in Section 5.2.1.2.

\subsubsection{1_Basic Process Chemistry}

The hydrothermal process of denitration is a variation of chemical reduction that occurs in waste solutions under supercritical or near supercritical conditions. Supercritical conditions are broadly defined as combinations of elevated temperatures between $350{ }^{\circ} \mathrm{C}$ and $525^{\circ} \mathrm{C}$ and pressures between 19 and $30 \mathrm{MPa}$.

In the hydrothermal treatment system, the aqueous waste containing nitrates and nitrites is contacted with a reducing agent in a pressurized vessel under the supercritical conditions described above for a period of several hours. The basic chemical reaction, with formic acid being the reductant, is as follows:

$$
2 \mathrm{NO}_{3}^{-}+5 \mathrm{HCOOH} \Longrightarrow \mathrm{N}_{2}+5 \mathrm{CO}_{2}+6 \mathrm{H}_{2} \mathrm{O} \text { (Equation 3) }
$$

Other reducing agents that have been tested on low-level mixed waste streams containing nitrates with varying degrees of effectiveness include ammonia, urea, methane, hydrogen, and potassium ferrocyanide. ${ }^{21}, 22$

Laboratory- and pilot-scale tests have shown that the process has the potential to destroy nitrates in both acidic and alkaline waste streams. The nitrates are converted almost entirely to nitrogen gas

${ }^{21}$ Taylor, P.A., Kurath, D.E., "Evaluation of Nitrate Destruction Methods," DOE/MWIP-10, March 30, 1993, pp. 17-18.

${ }^{22}$ Kapline Enterprises, Inc. “Aqueous Nitrate Waste Treatment: Technology Comparison, Cost / Benefit, and Market Analysis," DOE/OR 2013, January 1994, pp. 66-67. 
Rev. 0, 8/29/97

with small quantities of nitrous oxides also being produced. The organic reductants are converted to carbon dioxide.

\subsubsection{SRS-Specific Configuration}

A conceptual design for a full-scale hydrothermal process for treating decontaminated salt solution at the SRS has not heretofore been prepared. RCS speculates that the process flowsheet for such a plant would be similar to that presented on Figure 5-5.

In the RCS design, the decontaminated salt solution would be received from the ITP process and stored in two feed tanks. From these tanks, the decontaminated salt solution would be pumped under high pressure ( $>20 \mathrm{MPa}$ ) into the heated reactor vessel, where it would be contacted with a reducing agent for several minutes at temperatures above $350^{\circ} \mathrm{C}$.

The decontaminated salt solution does not contain organics in sufficient concentrations to function as effective reducing agents. Therefore, organic reductant (formic acid, kerosene, or other) would have to be added to the process, as illustrated on Figure 5-5.

Process off-gas would be piped to an air pollution control system, which would consist of a conventional $\mathrm{NO}_{x}$ scrubber system, demisters, reheaters, and HEPA filters.

Treated liquid would flow from the reactor to a steam-heated evaporator, where the dilute salt stream would be volume-reduced by approximately $70 \%$. The evaporated solution would then be pumped to the existing Z-Area Saltstone Facility for solidification and final disposal.

\subsubsection{Technical Evaluation}

The major advantages and disadvantages associated with this technology are discussed in Sections 5.2.2.1 and 5.2.2.2, respectively. The ability of the technology to meet the performance standards discussed in Section 3.4 is summarized in Section 5.2.2.3. The maturity of the technology and outstanding research and development needs are discussed in Section 5.2.2.4.

\subsubsection{1_Major Advantages}

Several major advantages are associated with the hydrothermal technology, including:

- The process works on both acidic and alkaline solutions.

- Organics in the waste are destroyed along with the nitrates and nitrites.

- It may be possible to separate and remove the salts and some radionuclides present in the treated liquid waste as solids, thereby facilitating the subsequent evaporation of the dilute liquid before solidification and final disposal. 


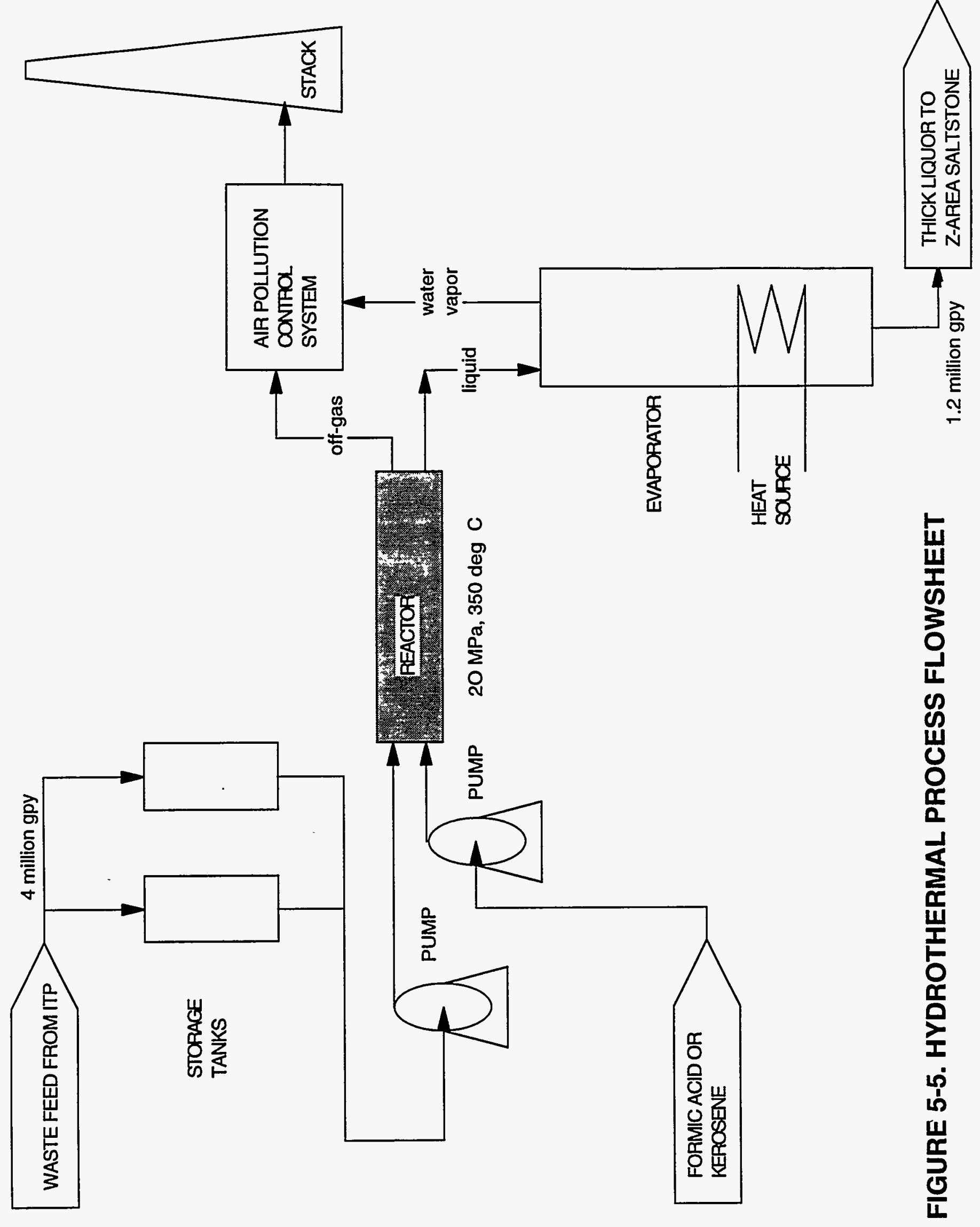


Rev. 0, 8/29/97

\section{$5.2 .2 .2 \quad$ Major Disadvantages}

The major disadvantages associated with this technology include the following:

- Plugging of the piping to and from the reactor is a concern because of the limited solubility of salts in supercritical solutions.

- The high temperatures and pressures within the reactor lead to high corrosion rates.

- Further processing of the off-gas may be needed to abate the nitrous oxides produced in the reactor.

\subsubsection{Potential to Meet Performance Standards}

The applicable performance standards were previously described in Section 3.4. An evaluation of this technology's ability to satisfy these performance standards follows.

\section{Nitrate/Nitrite Destruction and Separation Efficiency}

The hydrothermal process is capable of meeting the performance standard for nitrate and nitrite destruction. Testing at LANL has shown that destruction efficiencies in excess of $99 \%$ can be achieved for nitrates and nitrites. ${ }^{23}$ This destruction efficiency is greater than the performance criterion of $90 \%$.

\section{Worker Safety Standards}

The hydrothermal process does not pose inordinate dangers to workers. The potential worker hazards associated with high vessel pressures, hazardous off-gases, and radiation can be controlled using engineering and administrative controls.

\section{Process Safety Standards}

The hydrothermal facility would be classified as a low or moderate hazard facility. Under DOE Orders 5480.5 and 5481.1B, detailed safety analysis reports would be required before start-up.

Nothing in the published testing history of the hydrothermal process suggests that the process hazards associated with the high vessel pressures and elevated temperatures cannot be effectively controlled with appropriate design features and operating procedures. It is thus reasonable to conclude that a hydrothermal process can be constructed and operated to meet or exceed all applicable process safety standards.

${ }^{23}$ Robinson, J.M., etal, "Destruction of Nitrates, Organics, and Ferrocyanides by Hydrothermal Processing," LA-UR-93-456, 1993. 
Rev. 0, 8/29/97

\section{Radiological Safety Standards}

The only full-scale treatment systems for mixed wastes containing nitrates are the calciner at the ICPP and the DWPF and Duratek vitrifier at the SRS. The calciner and DWPF facilities process high-level aqueous wastes and routinely operate within the limits of applicable radiological safety standards. The Duratek vitrifier processes low-level mixed wastes and has operated for over a year within the limits of applicable radiological safety standards.

Given that the decontaminated salt solution contains much lower levels of radionuclides than the calciner and DWPF waste feeds and involves processing in enclosed pressure vessels, it is reasonable to conclude that a hydrothermal process can be designed and operated to meet all applicable radiological safety standards, including ALARA considerations. Shielding may be required around certain process areas.

\section{Environmental Standards}

The hydrothermal process is capable of meeting all applicable environmental standards. The product of hydrothermal treatment of decontaminated salt solution will be a dilute aqueous solution of sodium salts and radionuclides that should be amenable to solidification to a nonleaching Saltstone waste form. The process off-gas may require treatment for nitrous oxides, but this can probably be accomplished using established technologies. No wastewater will be produced in this process requiring surface water discharge.

\subsubsection{Technology Maturity and Research and Development Needs}

Extensive research of the hydrothermal treatment of mixed wastes has been ongoing at LANL, INEL, and other sites for 15 years. The hydrothermal process has been tested on a bench-scale at LANL.

A pilot plant that was to be located at the INEL was canceled 2 years ago. This pilot plant was going to be used to develop the data on scaling factors, materials, corrosion, thermodynamics, reaction kinetics, and operational hazards needed to design a full-scale plant. A full-scale hydrothermal treatment process for aqueous mixed wastes has not yet been designed or constructed.

Within the DOE complex, the research into hydrothermal processing has slowed considerably in recent years due to funding shortages and a paradigm shift toward privatization. However, R\&D in the private sector continues. General Atomics Corporation, Foster Wheeler, and others are presently involved in pilot-scale work related to the destruction of chemical agents (mustard, VX, $\mathrm{GB}$, and others). General Atomics, for example, recently treated 500 pounds of hydrolysate from the neutralization of VX with sodium hydroxide. ${ }^{24}$

${ }^{24}$ Telephone conversation between Mike Spritzer (General Atomics Corp.) And Mike Navetta (RCS Corp.), July 28, 1997. 
Rev. 0, 8/29/97

\subsubsection{Evaluation of Costs}

Section 5.2.3.1 discusses the capital costs of the hydrothermal waste treatment system. O\&M costs are discussed in Section 5.2.3.2. D\&D costs are estimated in Section 5.2.3.3. Life-cycle costs, computed on the basis of the capital, O\&M, and D\&D costs, are discussed in Section 5.2.3.4.

\subsubsection{Capital Cost}

A preliminary cost estimate for a hydrothermal system capable of processing 4 million gpy of alkaline nitrate wastes was prepared by RCS. The estimated capital cost for this system was $\$ 29$ million, as shown in Table 5-7.

\subsubsection{Qperations and Maintenance}

LANL reports that it has achieved incineration-like destruction removal using hydrothermal processing at a unit treatment cost of $\$ 0.05$ to $\$ 1.00$ per gallon. RCS believes these costs are overly optimistic and has estimated the O\&M cost of a nominal 4 million gpy hydrothermal plant, using the Delhi approach, to be $\$ 2.98$ million. This equates to a unit cost of $\$ 0.75$ per gallon. The estimates prepared by RCS are summarized in Table 5-8.

\subsubsection{Decontamination and Decommissioning Costs}

The D\&D costs for the denitration system have not been previously estimated. RCS estimates the $D \& D$ costs at the end of the operational life of the facility to be $\$ 500$ per square foot of process facility. Estimated D\&D costs, therefore, are $\$ 30$ million. 


\begin{tabular}{|l|l|l|}
\hline \multicolumn{3}{|c|}{ Table 5-7. Hydrothermal Plant Capital Cost Estimate } \\
(1997 Dollars)
\end{tabular}


Rev. 0, 8/29/97

\begin{tabular}{|l|l|l|l|}
\hline \multicolumn{4}{|c|}{ Table 5 - 8. Annual O\&M } \\
Costs, Hydrothermal System \\
\hline O\&M Item & Units & Unit Cost, \$ & Extension, \$ \\
\hline $\begin{array}{l}\text { Direct Labor (Fully Burdened) - } \\
\text { Operators }\end{array}$ & 8 & 60,000 & 480,000 \\
\hline $\begin{array}{l}\text { Direct Labor (Fully Burdened) - } \\
\text { Shift Supervisors }\end{array}$ & 4 & 75,000 & 300,000 \\
\hline $\begin{array}{l}\text { Process and Support Utilities - } \\
\text { electricity, HVAC, lighting, } \\
\text { potable water, sewer }\end{array}$ & 1 lot & $1,000,000$ & $1,000,000$ \\
\hline $\begin{array}{l}\text { Process Maintenance (5\% of } \\
\text { Capital Cost) }\end{array}$ & 1 lot & $1,000,000$ & $1,200,000$ \\
\hline Total & & & $\mathbf{2 , 9 8 0 , 0 0 0}$ \\
\hline
\end{tabular}

\section{2,3,4 Life-Cycle Costs}

For the purpose of estimating the present value of the total life-cycle cost for the denitration system, the following assumptions were made:

- Construction, O\&M, and D\&D costs will increase uniformly at $4 \%$ per year over the study period.

- RCRA and NEPA documentation will be prepared and all associated costs will be incurred in Year 0.

- Construction will begin in Year 0, and all capital costs will be incurred in that year.

- Operations will begin in Year 1 and continue for 25 years.

- D\&D will commence immediately following the 25-year service life and be completed in a 3-year period. D\&D costs will be evenly distributed across this 3-year period.

- The time value of money will be $8 \%$.

- The solid process residue will be stabilized in Saltstone at a unit cost of $\$ 4.86$ per gallon.

Given the above assumptions, the present value of the life-cycle costs is $\$ 168,230,000$, as listed in Table 5-9. 


\begin{tabular}{|l|l|l|}
\hline \multicolumn{3}{|c|}{ Table 5-9. Present Value, Hydrothermal System Life-Cycle Costs } \\
\hline Cost Item & Cost, \$ & Present Value, \$ \\
\hline Capital Cost & $29,330,000$ & $29,330,000$ \\
\hline RCRA Permits and Tests & 500,000 & 500,000 \\
\hline NEPA Documentation & 100,000 & 100,000 \\
\hline O\&M Cost & & \\
\hline Year 1 & $2,980,000$ & \\
\hline Total, Years 1-25 & $124,100,000$ & $45,500,000$ \\
\hline Residual Disposal & & \\
\hline Year 12.6 & $5,832,000$ & \\
\hline Total, Years 1-25 & $242,879,000$ & $89,044,000$ \\
\hline D\&D Cost & $30,000,000$ & $3,760,000$ \\
\hline Total & $\mathbf{3 9 6 , 9 0 9 , 0 0 0}$ & $\mathbf{1 6 8 , 2 3 4 , 0 0 0}$ \\
\hline $\begin{array}{l}\text { Notes } \\
\text { a Assumes disposal of 1.2 million gallons per year of liquid in Saltstone at a unit cost of } \\
\text { \$4.86 per gallon. } \\
\text { b Assumes wet scrubber blowdown is disposed at SRS Effluent Treatment Facility at a } \\
\text { unit cost of \$1.25 per gallon. }\end{array}$ \\
\hline
\end{tabular}

\subsubsection{Other Considerations}

Several other considerations impact the viability of the technology. These include the implementation schedule, secondary waste streams, pollution prevention, public acceptance, and regulatory permitting. Each is discussed in the ensuing sections of this report.

\subsubsection{1_Implementation Schedule}

The requirement to denitrate the alkaline wastes is short-term. To be viable for this application, the technology should be capable of (1) being implemented in a reasonably short period of time (i.e., less than 5 years) and (2) eliminating the anticipated inventory of 92 million gallons of alkaline waste at the SRS in 25 years or less.

Assuming that conventional DOE technology development and procurement methods are used, RCS believes that the full-scale hydrothermal process cannot be made operational in less than 5 years. Approximately 2 years of operations at the existing General Atomics or other pilot plant 
Rev. 0, 8/29/97

would be needed to develop design parameters for a full-scale plant. Thereafter, the time required to complete the design, construction, systemization, and permitting of the full-scale system would be approximately 4 to 6 years. At a minimum, 6 years would be needed to make a full-scale plant operational.

The experience with the Duratek vitrifier at the SRS indicates that it may be possible to substantially reduce the lead time discussed above by using the privatization approach.

\subsubsection{2_ Secondary Waste Streams}

The hydrothermal process should not produce large amounts of secondary waste streams. The only secondary waste stream of concern is the process off-gas, which could contain significant amounts of $\mathrm{NO}_{\mathrm{x}}$. This gas would require treatment using conventional abatement technologies prior to atmospheric discharge.

\subsubsection{Pollution Prevention}

The possibility of removing sodium salts and radionuclides as solids from the reactor provides an opportunity to reduce the volume of the treated liquid using evaporation. It is conceivable that $70 \%$ reductions in the volume of mixed waste requiring land disposal can be realized using posttreatment evaporation in conjunction with the hydrothermal process. This will result in substantial savings in disposal costs and is very attractive from a pollution prevention standpoint.

\subsubsection{Public Acceptance}

Heretofore, the hydrothermal process has not been widely publicized. There is no organized opposition to the technology from environmental or citizens groups. All indications are that the public would be supportive of the use of hydrothermal technology to treat the decontaminated salt solution.

\subsubsection{5_Regulatory Permitting}

The hydrothermal process will require a RCRA Part B permit and an air pollution permit from the South Carolina Department of Health and Environmental Control. These permits will be similar in complexity to those acquired by DOE for the Consolidated Incineration Facility (CIF) at the SRS. RCS believes that the permitting process could require upwards of 24 months to complete.

\section{$\mathbf{5 , 2 . 4 . 6 \quad V e r s a t i l i t y}$}

The hydrothermal process could be used to treat radioactive, mixed, and hazardous wastes that contain organics. Numerous waste streams generated at the SRS could be treated in a hydrothermal plant. 
Rev. 0, 8/29/97

\subsection{CHEMICAL REDUCTION PROCESSES}

This section of the report discusses the technical and economic aspects of the chemical denitration of low-level alkaline mixed waste streams.

\subsubsection{Process Engineering Description}

The basic stoichiometry of the chemical denitration (i.e., reduction) of nitrates and nitrites is described in Section 5.3.1.1. A description of a preconceptual design for a chemical reduction system for SRS waste streams based on the nitrate to ammonia and ceramic (NAC) process of chemical reduction is presented in Section 5.3.1.2.

\subsubsection{1_Basic Process Chemistry}

The chemical reduction of nitrates and nitrites involves the use of reducing agents, such as ascorbic acid, formaldehyde, formic acid, or aluminum, to convert the nitrates and nitrites to simpler oxides of nitrogen $\left(\mathrm{NO}_{x}\right)$, ammonia, and nitrogen gas. In general, the processes that use organic reductants have been in use by the chemical industry for over a century. The processes that use metal reductants are more contemporary.

Numerous parallel and sequential reduction reactions occur in solutions of nitrates and nitrites during chemical reduction. Examples of these reactions, using formic acid and aluminum as reducing agents, are as follows:

\section{Formic Acid}

$$
\begin{aligned}
& 2 \mathrm{NO}_{3}^{-}+\mathrm{HCOOH} \Longrightarrow 2 \mathrm{NO}_{2}^{-}+\mathrm{CO}_{2}+2 \mathrm{H}_{2} \mathrm{O} \text { (Equation 4) } \\
& 2 \mathrm{NO}_{3}^{-}+5 \mathrm{HCOOH}=\mathrm{N}_{2}+5 \mathrm{CO}_{2}+6 \mathrm{H}_{2} \mathrm{O} \text { (Equation 5) }
\end{aligned}
$$

\section{Aluminum}

$$
3 \mathrm{NaNO}_{3}+8 \mathrm{Al}+12 \mathrm{H}_{2} \mathrm{O} \rightleftharpoons 3 \mathrm{NH}_{3}+5 \mathrm{Al}(\mathrm{OH})_{3}+3 \mathrm{NaAlO}_{2} \text { (Equation 6) }
$$

Formaldehyde and formic acid have been used in France and Japan for many years to denitrate high-level wastes containing high concentrations of nitric acid. The French and Japanese applications of chemical reduction technology have been geared primarily toward neutralizing strong nitric acid solutions rather than destroying nitrates. No experience in France and Japan has applied this technology to the destruction of nitrates in alkaline mixed waste streams.

The experience in Japan and France shows that chemical reduction using organic reductants does not destroy a high fraction of the nitrate in solution and does not work on alkaline wastes. ${ }^{25}$

${ }^{25}$ Kapline Enterprises, Inc., "Aqueous Nitrate Waste Treatment: Technology Comparison, . Cost/Benefit, and Market Analysis," DOE/OR 2013, January 1994, p. 44. 
Rev. 0, 8/29/97

Conventional chemical reduction technology using organic reductants is, therefore, not further considered in this report. All further discussions of chemical reduction focus on processes that use metal reductants.

In the U.S., researchers at the ORNL and Florida International University have been developing the innovative NAC chemical reduction process for several years. The NAC process uses aluminum as the reductant. The basic process flow diagram is provided on Figure 5-6.

The NAC process, which is highly exothermic, occurs in alkaline solutions at temperatures above $50^{\circ} \mathrm{C}$ with the addition of aluminum, water, and silica. The reaction of nitrate and aluminum in solution produces a granular, sand-like product slurry, and an off-gas stream containing ammonia and hydrogen. The sand-like product can be dried in a calciner, pressed, and sintered at 600 to 800 ${ }^{\circ} \mathrm{C}$ in a furnace to a ceramic waste form with a high bulk density $\left(>2 \mathrm{~g} / \mathrm{cm}^{3}\right)$, very small pore size, and low leachability. Leach testing on sintered material produced from ORNL wastes have shown that the matrix passes the EPA Toxicity Characteristic Leaching Procedure (TCLP) test and has a leach index for radionuclides comparable to that of glass waste forms. ${ }^{26}$ The ammonia off-gas from the NAC reactor can be catalytically oxidized to nitrogen and water.

Experiments with ORNL and Hanford wastes indicate that a waste volume reduction of $70 \%$ can be achieved using the NAC process. These experiments also indicate that ${ }^{90} \mathrm{Sr}$ and other heavy metals will precipitate in the NAC reactor and become chemically bound in the ceramic product, as evidenced by the leach tests described above.

With slight process modifications, the sand-like product can be immobilized in portland cement or vitrified to glass. A variation of the NAC process is the nitrate to ammonia and glass (NAG) process. In the NAG process, the sintering furnace is replaced with a high temperature vitrifier. The product is a glass waste form, instead of a ceramic.

\subsubsection{SRS-Specific Configuration}

The decontaminated salt solution waste stream at the SRS is a dilute solution of sodium nitrate, nitrite, and hydroxide, as stated in Section 3.1 of this report. The results of testing performed on similar wastes at Hanford and ORNL indicate that a process with the same basic configuration shown on Figure 5-6 could probably be used to denitrate the SRS waste using NAC technology.

${ }^{26}$ Kapline Enterprises, Inc., "Aqueous Nitrate Waste Treatment: Technology Comparison, Cost/Benefit, and Market Analysis," DOE/OR 2013, January 1994, p. 59. 


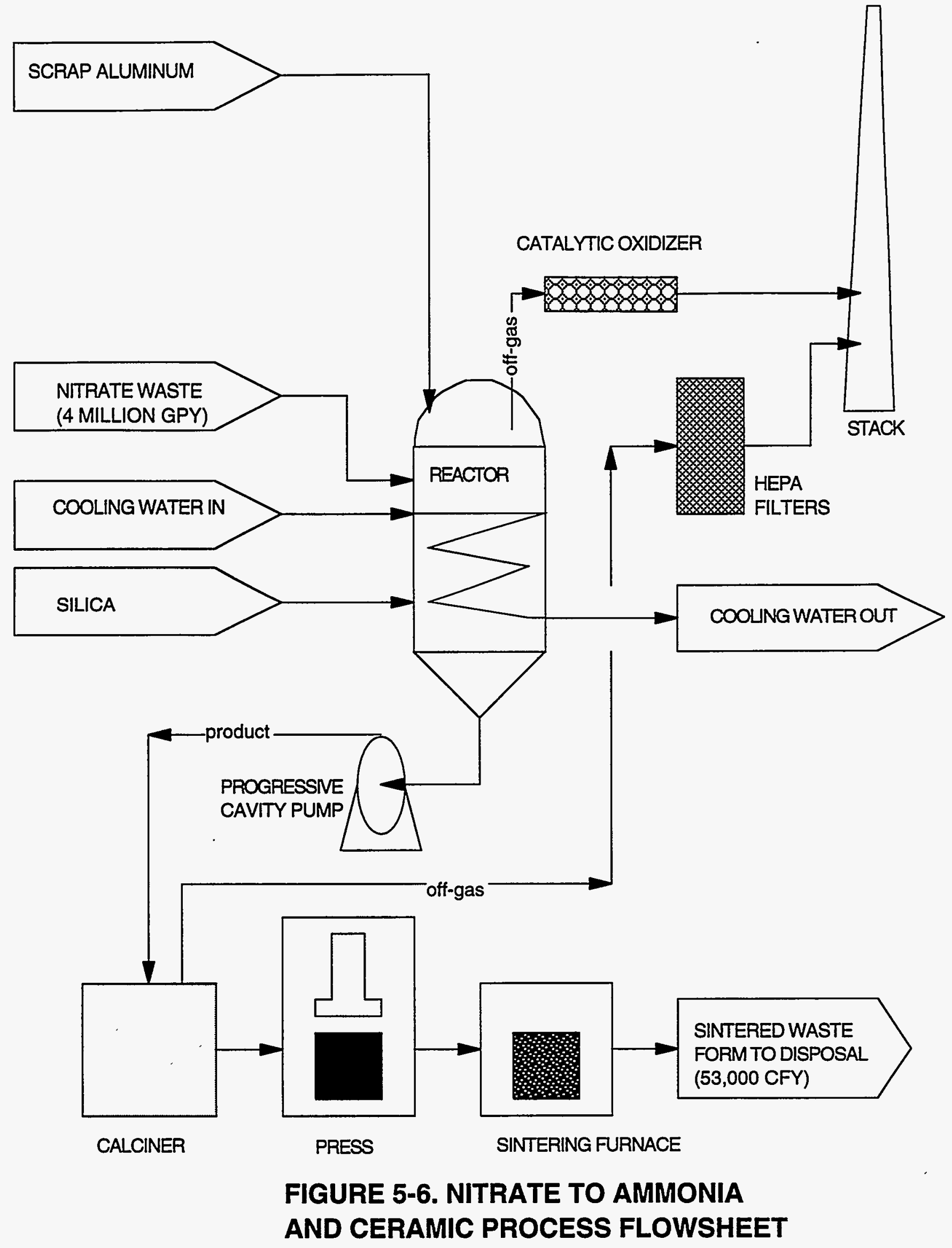


Rev. 0, 8/29/97

Assuming a reactor residence time of 2 hours, a nominal capacity of 4 million gpy, and a design availability of $70 \%$, the SRS plant would consist of the following major equipment housed in a 60,000-square-foot building:

- Reactor, 5000 gallons

- Waste Feed Tanks (2), 15,000 gallons each

- Liquid Product Storage Tanks (2), 15,000 gallons each

- Slurry Product Storage Tanks (2), 5,000 gallons each

- Calciner, 6 million BTU/hr

- Hydrostatic Press

- Sintering Furnace, 1 million BTU/hr

\subsubsection{Technical Evaluation}

The major advantages and disadvantages associated with this technology are discussed in Sections 5.3.2.1 and 5.3.2.2, respectively. The ability of the technology to meet the performance standards discussed in Section 3.4 is summarized in Section 5.3.2.3. The maturity of the technology and outstanding research and development needs are discussed in Section 5.3.2.4.

\subsubsection{Major Advantages}

Several major advantages are associated with the NAC technology, including:

- Waste feed streams would not require pretreatment.

- The NAC process would yield an insoluble solid waste form that may be suitable for land disposal without further treatment.

- The NAC process could use radioactively-contaminated scrap aluminum as a feed material, thereby reducing the decontamination and disposal requirements for that material.

- The NAC process would operate at low temperatures.

\section{$\mathbf{5 . 3 . 2 . 2} \quad$ Major Disadvantages}

The major disadvantages associated with this technology include the following:

- The chemical reduction of nitrates is highly exothermic and would require strict 
engineering controls to prevent runaway reaction.

- Process off-gases containing hydrogen, ammonia, and $\mathrm{NO}_{\mathrm{x}}$ would be produced and would require treatment prior to atmospheric discharge.

\section{5,3,2.3 Potential to Meet Performance Standards}

The applicable performance standards were previously described in Section 3.4. An evaluation of this technology's ability to satisfy these performance standards is presented below.

\section{Nitrate/Nitrite Destruction and Separation Efficiency}

The NAC process is capable of meeting the performance standard for nitrate and nitrite destruction. Testing on ORNL and Hanford waste streams has shown that destruction efficiencies in excess of $99 \%$ can be achieved for nitrates and nitrites. This destruction efficiency is greater than the performance criterion of $90 \%$.

\section{Worker Safety Standards}

The NAC process is a low temperature process that does not pose inordinate dangers to workers. The potential worker hazards associated with exothermic reactions, hazardous off-gases, and radiation could be controlled using engineering and administrative controls.

\section{Process Safety Standards}

The NAC facility would be classified as a low or moderate hazard facility. Under DOE Orders 5480.5 and $5481.1 B$, detailed safety analysis reports would be required before start-up.

The NAC chemical reduction process is highly exothermic. The literature suggests that in the absence of reactor cooling, runaway reactions are possible. Nothing in the NAC testing history, however, suggests that the process hazards associated with the exothermic nature of the chemical reactions could not be effectively controlled with appropriate design features and operating procedures.

Considering the facts discussed above, the NAC process design would have to include a highly reliable, or perhaps redundant, reactor cooling system. Cooling systems of this type are common in both the chemical and nuclear industries. Thus, it is reasonable to conclude that a NAC process can be constructed and operated to meet or exceed all applicable process safety standards.'

\section{Radiological Safety Standards}

The only full-scale mixed waste treatment system for nitrates is the calciner at the ICPP. This facility processes high-level aqueous wastes and routinely operates within the limits of applicable radiological safety standards. 
Rev. 0, 8/29/97

Given that the decontaminated salt solution contains much lower levels of radionuclides than the ICPP waste feed, it is reasonable to conclude that a NAC process could be designed and operated to meet all applicable radiological safety standards, including ALARA considerations. To achieve full compliance, the reactor and cooling systems would have to be designed to control the highly exothermic reactions and minimize exposures to O\&M personnel. Shielding may also be required around certain process areas.

\section{Environmental Standards}

The NAC process is capable of meeting all applicable environmental standards. The treatment process solid residual is reported to be nonleaching and thus may be suited for land disposal without further treatment. The treatment process off-gas may contain high-levels of hydrogen, ammonia, and $\mathrm{NO}_{\mathrm{x}}$ that could be effectively abated using commercially available air pollution control equipment. The NAC process would not generate significant quantities of wastewater and would not directly affect surface waters.

\subsubsection{Technology Maturity and Research and Development Needs}

The NAC process has been tested on a bench-scale at ORNL. Engineering plans for a pilot-scale NAC process were completed in 1995 , but the construction has been indefinitely deferred because of DOE funding shortages. ${ }^{27}$ Pilot-scale testing, therefore, remains to be completed.

\subsubsection{Evaluation of Costs}

Section 5.3.3.1 discusses the capital costs of the electrochemical waste treatment system. O\&M costs are discussed in Section 5.3.3.2. D\&D costs are estimated in Section 5.3.3.3. Life-cycle costs, computed on the basis of the capital, O\&M, and D\&D costs, are discussed in Section 5.3.3.4.

\subsubsection{Capital Cost}

The Central Engineering Department at ORNL prepared a preliminary cost estimate in 1992 for a NAC system capable of processing 24,000 gallons per day (gpd) of alkaline nitrate wastes (6.1 million gpy @ 70\% availability). The estimated capital cost for this system was $\$ 20$ million.

As shown in Table 5-8, it is estimated that a 4 million gpy NAC system would cost approximately $\$ 21.8$ million (1997 dollars) to construct at the present time.

${ }^{27}$ Personal communication between A.J. Mattus (ORNL) and Mike Navetta (RCS), July 18, 1997. 


\begin{tabular}{|c|c|c|}
\hline \multicolumn{3}{|c|}{ Table 5-8. NAC Capital Cost Estimate (1997 Dollars) } \\
\hline Item & Size & Cost, $\$$ \\
\hline Feed Tanks (2) & 15,000 gallons each & $170,000^{\mathrm{a}}$ \\
\hline Liquid Product Tanks (2) & $15 ; 000$ gallons each & $120,000^{a}$ \\
\hline Slurry Product Tanks (2) & 5,000 gallons each & $70,000^{a}$ \\
\hline Reactor Vessel & $\begin{array}{l}5,000 \text { gallons, } \\
\text { atmospheric working } \\
\text { pressure, glycol-cooled }\end{array}$ & $160,000^{\mathrm{b}}$ \\
\hline Reactor Cooling System & 400 tons & 400,000 \\
\hline Slurry Feed Pumps (2) & $100 \mathrm{gpm}$ & 50,000 \\
\hline Reactor Discharge Pumps (2) & $25 \mathrm{gpm}$ & 30,000 \\
\hline Aluminum Feed System & $2000 \mathrm{lb} / \mathrm{hr}$ & 150,000 \\
\hline Sludge Dryer & $5,000 \mathrm{lb} / \mathrm{hr}$ & 100,000 \\
\hline Calciner & 6 million BTU/hr & 350,000 \\
\hline Ammonia Burner & $1000 \mathrm{cfm}$ & 100,000 \\
\hline Subtotal, Major Equipment & & $1,700,000$ \\
\hline $\begin{array}{l}\text { Miscellaneous Equipment @ } 30 \% \text { of Major } \\
\text { Equipment }\end{array}$ & & 510,000 \\
\hline Equipment Installation, $50 \%$ of Major Equipment & & 850,000 \\
\hline Facilities@ @ $\$ 200 / \mathrm{ft}^{2}$ & $60,000 \mathrm{ft}^{2}$ & $12,000,000$ \\
\hline Subtotal, Installed Equipment and Facilities & & $15,060,000$ \\
\hline Engineering, $15 \%$ & & $2,260,000$ \\
\hline Management Reserve, $30 \%$ & & $4,520,000$ \\
\hline TOTAL COST & & $21,840,000$ \\
\hline $\begin{array}{ll}\text { Notes } & \\
\text { a } & \text { Verbal quotations from John Wood Co. of } \\
\text { b } & \text { Fabrication Inc., Grand Prairie, TX. } \\
\text { Verbal quotation from Dan Leonard of Pau }\end{array}$ & $\begin{array}{l}\text { Valley Forge, } \mathrm{PA} \text { and } \mathrm{Da} \\
\text { I Mueller Co., Springfiel }\end{array}$ & $\begin{array}{l}\text { Worth } \\
\text { MO. }\end{array}$ \\
\hline
\end{tabular}


Rev. 0, 8/29/97

\subsubsection{Operations and Maintenance}

ORNL's Central Engineering Department estimated the O\&M costs for a NAC plant to be $\$ 2$ to $\$ 3$ per kg of nitrate destroyed. The SRS wastes could contain nitrates in concentrations up to $6 \mathrm{M}$. Assuming the ORNL estimates are accurate, the O\&M costs for a NAC plant at the SRS should be upward of $\$ 1$ per gallon or $\$ 4$ million annually.

Independent estimates of O\&M costs for a nominal 4 million gpy NAC plant were prepared by RCS using a Delphi approach. These estimates, provided in Table 5-9, total $\$ 2.87$ million annually. These O\&M costs, which are slightly lower than the ORNL figures, correspond to a unit treatment cost of $\$ 0.72$ per gallon.

\begin{tabular}{|l|l|l|l|}
\hline \multicolumn{4}{|c|}{$\begin{array}{c}\text { Table 5-9. Annual O\&M Costs, } \\
\text { NAC Denitratión System }\end{array}$} \\
\hline O\&M Item & Units & Unit Cost, \$ & Extension, \$ \\
\hline $\begin{array}{l}\text { Direct Labor (Fully Burdened) - } \\
\text { Operators }\end{array}$ & 8 & 60,000 & 480,000 \\
\hline $\begin{array}{l}\text { Direct Labor (Fully Burdened) - } \\
\text { Shift Supervisors }\end{array}$ & 4 & 75,000 & 300,000 \\
\hline $\begin{array}{l}\text { Process and Support Utilities - } \\
\text { electricity, HVAC, lighting, } \\
\text { potable water, sewer }\end{array}$ & 1 lot & $1,000,000$ & $1,000,000$ \\
\hline $\begin{array}{l}\text { Process Maintenance (5\% of } \\
\text { Capital Cost) }\end{array}$ & 1 lot & $1,100,000$ & $1,090,000$ \\
\hline Total & & & $\mathbf{2 , 8 7 0 , 0 0 0}$ \\
\hline
\end{tabular}

\subsubsection{Decontamination and Decommissioning Costs}

An estimate of the D\&D costs for the NAC denitration system has not been prepared. RCS estimates the D\&D costs at the end of the operational life of the facility to be $\$ 500$ per square foot of process facility. Estimated D\&D costs, therefore, are $\$ 30$ million.

\subsubsection{Life-Cycle Costs}

For the purpose of estimating the present value of the total life-cycle cost for the denitration system, the following assumptions were made:

- Construction, O\&M, and D\&D costs will increase uniformly at $4 \%$ per year over the study period. 
Rev. 0, 8/29/97

- RCRA and NEPA documents will be prepared and associated costs will be incurred in Year 0.

- Construction will begin in Year 0, and all capital costs will be incurred in that year.

- Operations will begin in Year 1 and continue for 25 years.

- D\&D will commence immediately following the 25-year service life and will be completed in a 3-year period. D\&D costs will be evenly distributed across the 3-year period.

- The time value of money will be $8 \%$.

- The solid NAC process residue will be delisted and disposed of as low-level radioactive waste at a unit cost of $\$ 52$ per cubic foot.

Given the above assumptions, the present value of the life-cycle costs is $\$ 112$ million, as listed in Table 5-10.

\subsubsection{Other Considerations}

Several other considerations may impact the viability of the technology. These include the implementation schedule, secondary waste streams, pollution prevention, public acceptance, and regulatory permitting. Each is discussed in the ensuing sections of this report.

\subsubsection{Implementation Schedule}

The requirement to denitrate the alkaline wastes is short-term. To be viable for this application, the technology should be capable of (1) being implemented in a reasonably short period of time (i.e., less than 5 years) and (2) eliminating the anticipated inventory of 92 million gallons of alkaline waste at the SRS in 25 years or less.

In the event that the conventional DOE technology development and procurement process is followed, RCS believes that the full-scale NAC process could not be made operational in less than 5 years. RCS estimates that a full-scale chemical reduction process using NAC technology would require at least 6 years.to become operational. Assuming the availability of funding, approximately 2 years would be needed to construct a pilot plant. Another year of pilot-scale testing would follow to refine the process flowsheet and establish operational settings. Thereafter, the design, construction, systemization, and permitting of the full-scale system could be completed in 4 years.

As stated previously, the experience with privatization at the SRS suggests that the lead time could be reduced to 5 years or less if the privatization approach were used. 
Rev. 0, 8/29/97

\begin{tabular}{|c|c|c|}
\hline \multicolumn{3}{|c|}{ Table 5-10. Present Value, NAC System Life-Cycle Costs } \\
\hline Cost Item & Cost, $\$$ & Present Value, $\$$ \\
\hline Capital Cost & $21,840,000$ & $21,840,000$ \\
\hline RCRA Permit and Tests & 500,000 & 500,000 \\
\hline NEPA Documents & 100,000 & 100,000 \\
\hline \multicolumn{3}{|l|}{ O\&M Cost } \\
\hline Year 1 & $2,870,000$ & \\
\hline Total, Years 1-25 & $119,520,000$ & $43,820,000$ \\
\hline \multicolumn{3}{|l|}{ Residue Disposal ${ }^{\mathrm{a}, \mathrm{b}}$} \\
\hline Year 1 & $2,756,000$ & \\
\hline Total, Years $1-25$ & $114,776,000$ & $42,079,000$ \\
\hline D\&D Cost & $30,000,000$ & $3,760,000$ \\
\hline Total & $286,736,000$ & $112,099,000$ \\
\hline \multicolumn{3}{|c|}{$\begin{array}{l}\text { Notes } \\
\text { a Assumes overall volume reduction of } 70 \% \text { and disposal of process residuals as low- } \\
\text { b level waste at a unit cost of } \$ 52 \text { per cubic foot. } \\
\text { Assumes wet scrubber blowdown is disposed at SRS Effluent Treatment Facility at a } \\
\text { unit cost of } \$ 1.25 \text { per gallon. }\end{array}$} \\
\hline
\end{tabular}

\subsubsection{Secondary Waste Streams}

The NAC process should not produce large amounts of secondary waste streams. The only secondary waste stream of concern is the process off-gas, which could contain significant amounts of hydrogen, ammonia, and $\mathrm{NO}_{\mathrm{x}}$. These gases would require treatment using conventional abatement technologies prior to atmospheric discharge.

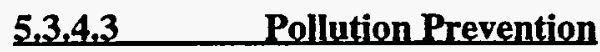

Bench-scale testing indicates that $70 \%$ reductions in the volume of mixed waste requiring land disposal could be realized using the NAC process. This would result in substantial savings in disposal costs and would be very attractive from a pollution prevention standpoint.

\subsubsection{Public Acceptance}

Heretofore, the NAC process has not been widely publicized. There is no organized opposition to 
the technology from environmental or citizens groups. All indications are that the public would be supportive of the use of NAC technology to treat the decontaminated salt solution.

\subsubsection{Regulatory Permitting}

The NAC process would require a RCRA Part B permit and an air pollution permit from the South Carolina Department of Health and Environmental Control. These permits would be relatively easy to acquire and would be much less expensive than the permits acquired by DOE for the Consolidated Incineration Facility (CIF) at the SRS. RCS believes that the permitting process could be completed in 12 to 24 months.

\subsubsection{Versatility}

The applicability of the NAC process is limited primarily to radioactive, mixed, and hazardous wastes that contain nitrates. The process is less versatile than the thermal and hydrothermal alternatives.

\section{$5.4 \quad$ ELECTROCHEMICAL REDUCTION PROCESS}

This section of the report discusses the technical and economic aspects of the electrochemical process of denitrating low-level alkaline mixed waste streams.

\subsubsection{Process Engineering Description}

The basic process stoichiometry is described in Section 5.4.1.1. A description of a preconceptual design for an electrolysis system for SRS waste streams is presented in Section 5.4.1.2.

\subsubsection{Basic Process Chemistry}

The electrochemical process of liquid waste treatment is conducted in an electrolytic cell (electrolyser) consisting of an electrolyte reservoir, the electrolyte (untreated liquid waste), an anode, and a cathode (refer to Figure 5-7).

Within the electrolytic cell, an electric potential is maintained across the anode and cathode to provide the driving force for oxidation reactions that occur at the anode and reduction reactions that occur at the cathode. At the cathode, electrons are supplied to reduce electroactive species in the electrolyte. At the anode, electroactive species release electrons and are oxidized. 


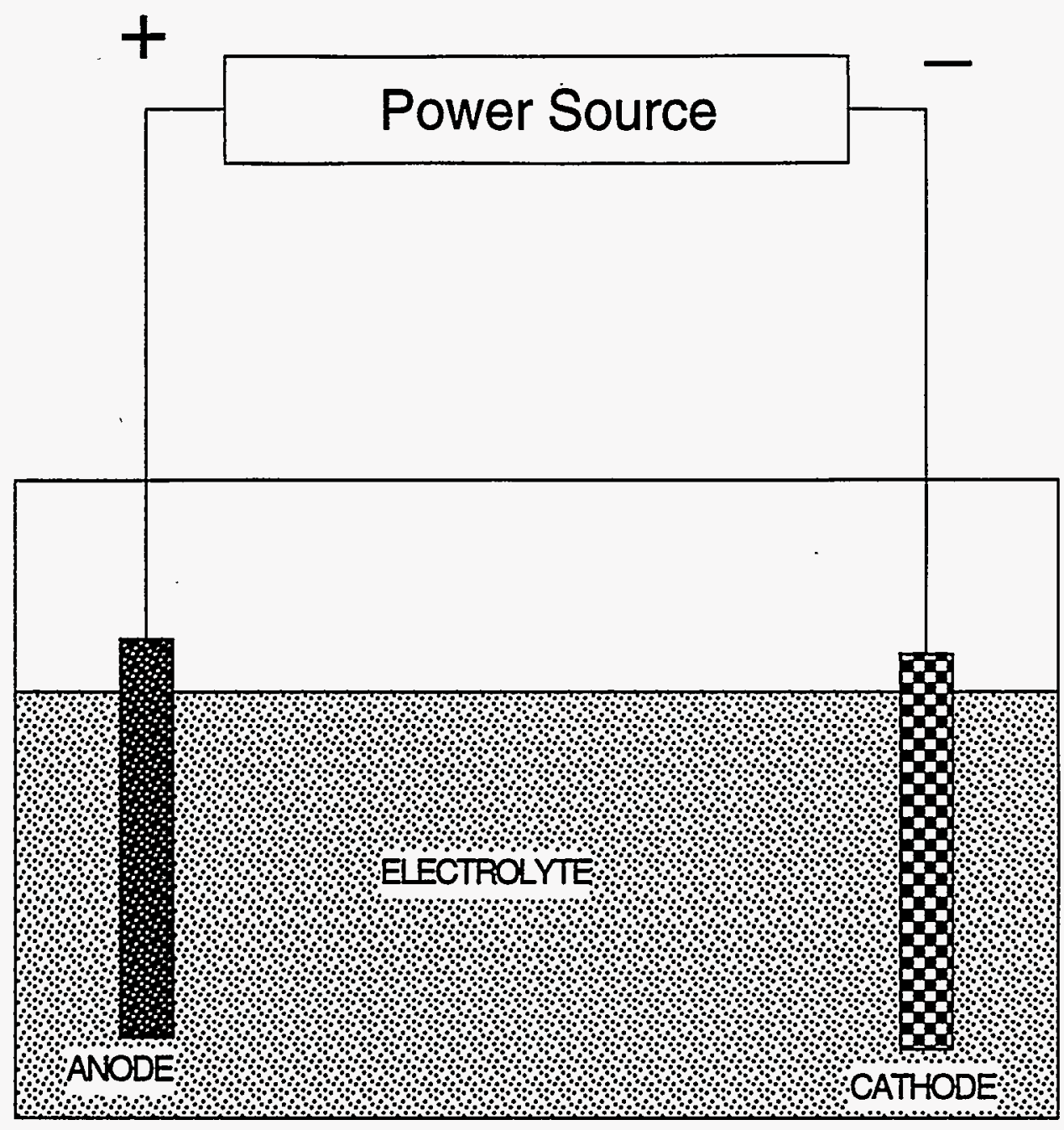

FIGURE 5-7. TYPICAL ELECTROCHEMICAL CELL 
Rev. 0, 8/29/97

The electrochemical destruction of nitrates in an electrolyte solution is brought about by the reduction of the nitrate and nitrite at the cathode to nitrogen and ammonia, as shown on Figure 58. Numerous parallel and sequential reduction reactions occur at the cathode, including but not limited to, the following:

$$
\begin{aligned}
& \mathrm{NO}_{3}^{-}+\mathrm{H}_{2} \mathrm{O}+2 \mathrm{e}^{-} \Longrightarrow \mathrm{NO}_{2}^{-}+2 \mathrm{OH}^{-} \text {(Equation 7) } \\
& \mathrm{NO}_{2}^{-}+5 \mathrm{H}_{2} \mathrm{O}+6 \mathrm{e}^{-} \Longrightarrow \mathrm{NH}_{3}+7 \mathrm{OH}^{-} \text {(Equation 8) } \\
& \mathrm{NO}_{3}^{-}+6 \mathrm{H}_{2} \mathrm{O}+8 \mathrm{e}^{-}=\mathrm{NH}_{3}+9 \mathrm{OH}^{-} \text {(Equation 9) } \\
& 2 \mathrm{NO}_{3}^{-}+6 \mathrm{H}_{2} \mathrm{O}+10 \mathrm{e}^{-}==\Rightarrow \mathrm{N}_{2}+12 \mathrm{OH}^{-} \text {(Equation 10) }
\end{aligned}
$$

At the anode, organic species dispersed in the electrolyte are oxidized, primarily to carbon dioxide and water.

In the case of aqueous electrolytes, competing electrolysis reactions are the oxidation and reduction of water to oxygen and hydrogen.

Metal cations in the electrolyte may be reduced at the cathode and plate out as insoluble salts or pure metal on the cathode.

The kinetics of typical electrolysis reactions in electrochemical cells are governed by both mass transport (electroactive species diffusion through the electrolyte solution to the electrodes) and surface phenomena. Due to the latter, the presence of significant concentrations of metals in the electrolyte that reduce to insoluble salts at the cathode can lead to poisoning of the cathode and greatly reduce the electrolysis efficiency. This effect is, according to the literature, especially pronounced when chromates are present in the waste.

The reduction of chromate at the cathode forms insoluble chromium hydroxide films that are impermeable to some electronegative species, including nitrates. ${ }^{28,29,30}$ In experiments conducted using actual and simulated wastes, the electrolysis efficiency has been shown to decrease from over $90 \%$ to less than $40 \%$ in the presence of chromium at a concentration of $16 \mathrm{mg} / \mathrm{L}$. At a chromium concentration of $318 \mathrm{mg} / \mathrm{L}$, the electrolysis efficiency was observed to drop to less than

${ }^{28}$ Chai, D., Hartsough, D., Genders, D., "Electrochemical Processing of Hanford and SRS Waste Simulants using an ICI FM21-SP Pilot Scale Flow Cell," Electrosynthesis Co., Inc., September 14, 1995.

${ }^{29}$ Hobbs, D. T., "Electrolytic Denitration of Radioactive Savannah River Site Waste," WSRC-TR-95-0176, April 26, 1995.

${ }^{30} \mathrm{Hobbs,} \mathrm{D.} \mathrm{T.,} \mathrm{"Summary} \mathrm{Technical} \mathrm{Report} \mathrm{on} \mathrm{the} \mathrm{Electrochemical} \mathrm{Treatment} \mathrm{of} \mathrm{Alkaline}$ Nuclear Wastes," WSRC-TR-94-0287, July 30, 1994. 


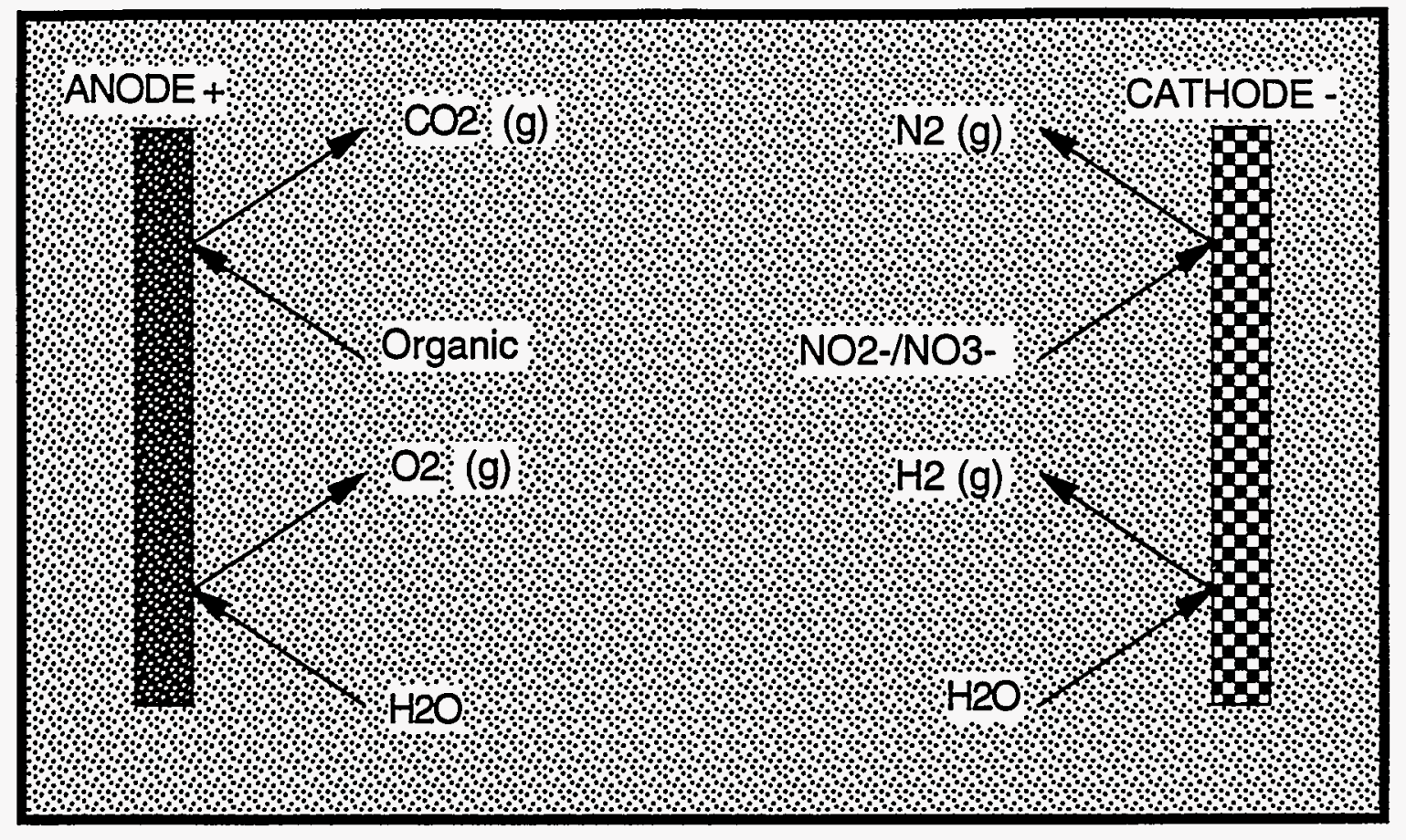

FIGURE 5-8. REDUCTION OF NITRATE/NITRITE IN ELECTROLYSER 
Rev. 0, 8/29/97

$10 \% .^{31.32}$

The designs of electrochemical cells are various and incorporate numerous combinations of divided, undivided, batch, and flow-through cell configurations. A schematic of a typical undivided flow-through electrochemical cell is provided on Figure 5-9.

\subsubsection{SRS-Specific Configuration}

The alkaline nitrate-bearing waste streams at the SRS are dilute solutions of sodium nitrate, nitrite, and hydroxide. During experiments conducted at the SRS and other locations in recent years, the nitrates and nitrites in these wastes were essentially completely destroyed in an industrial flowthrough electrolyser. The reduction and oxidation products included nitrogen, ammonia, sodium hydroxide $(\mathrm{NaOH})$, oxygen, and hydrogen. ${ }^{33}$

In 1996, Bechtel Savannah River, Inc., completed the preconceptual design of an electrochemical denitration system for the alkaline nitrate-bearing wastes at the SRS. The design capacity of the process is approximately 2 million gpy. This capacity is significantly below the design basis of 4 million gpy. WSRC personnel report, however, that with the addition of extra electrolyser cells and the replacement of electrolyte pumps with larger units, the design prepared by Bechtel could be easily upgraded to 4 million gpy.

The principal components of the upgraded process would be two parallel banks of five electrolysers in series, two 20,000-gallon liquid storage tanks, liquid waste feed pumps, and an offgas treatment system. The simplified process flow diagram is provided on Figure 5-10..$^{34}$ The design calls for the process to be located in a 60,000 -square-foot steel building.

In the upgraded preconceptual design, the alkaline wastes would be received in discrete batches in Tank TK-1. The batch processing time would be 50 hours. From Tank TK-1, the wastes would be

${ }^{31}$ Hobbs, D. T., Ebra, M. A., "Electrochemical Processing of Nitrate and Nitrite Solutions," AIChE Symposium Ser. 83(254), pp. 149-155, 1987.

${ }^{32}$ Taylor, P. A., Kurath, D. E., "Evaluation of Nitrate Destruction Methods," DOE/MWIP-10, March 30, 1993.

${ }^{33}$ Chai, D., Hartsough, D., Genders, D., "Electrochemical Processing of Hanford and SRS Waste Simulants using an ICI FM21-SP Pilot Scale Flow Cell," Electrosynthesis Co., Inc., September 14, 1995.

${ }^{34}$ Bechtel Savannah River, Inc., "Preconceptual Design Study for the Salt Solution Electrochemical Denitration and Caustic Recovery Facility," WAD \# LIW2EE002, Rev. C, September 5, 1996. 


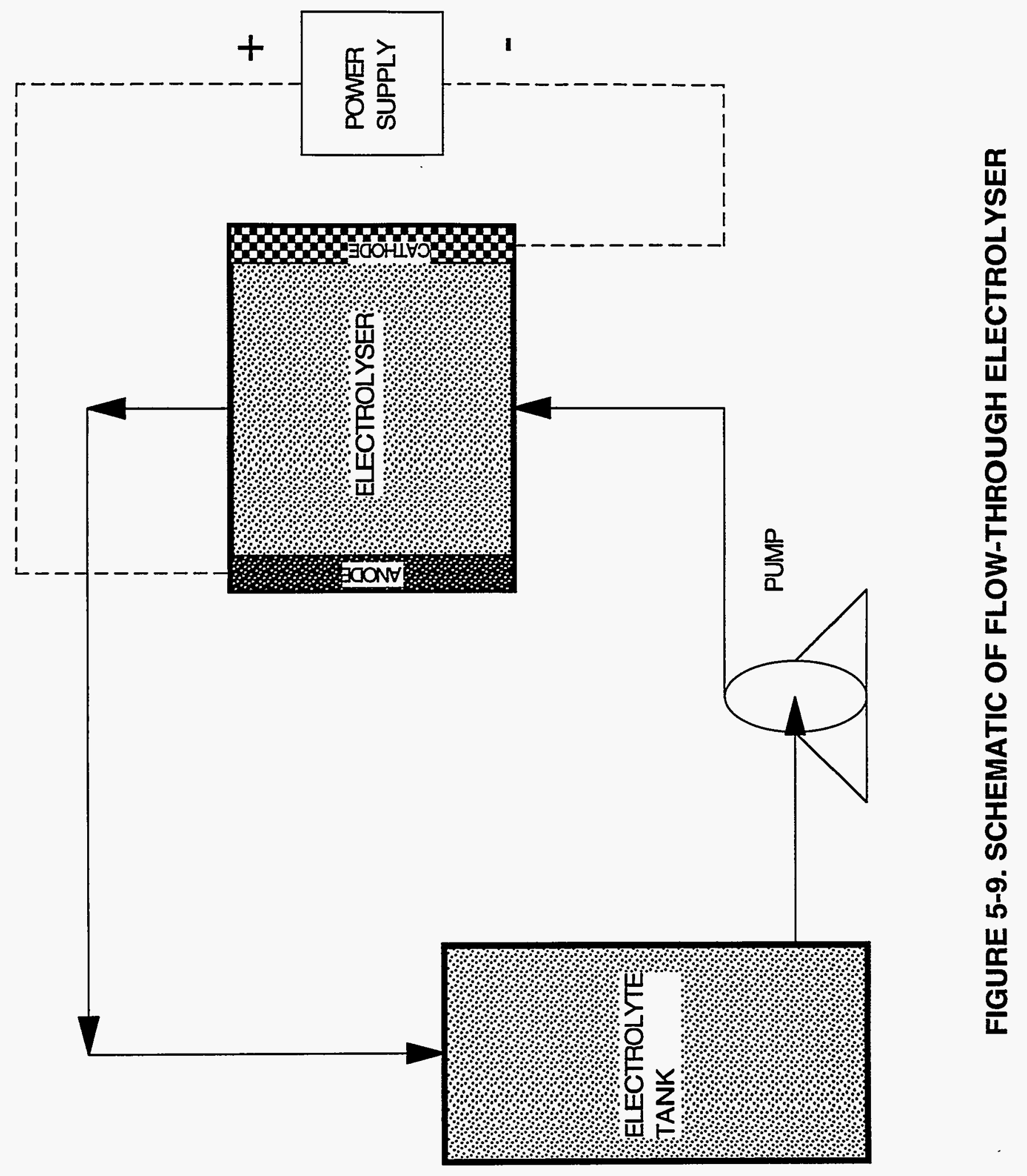




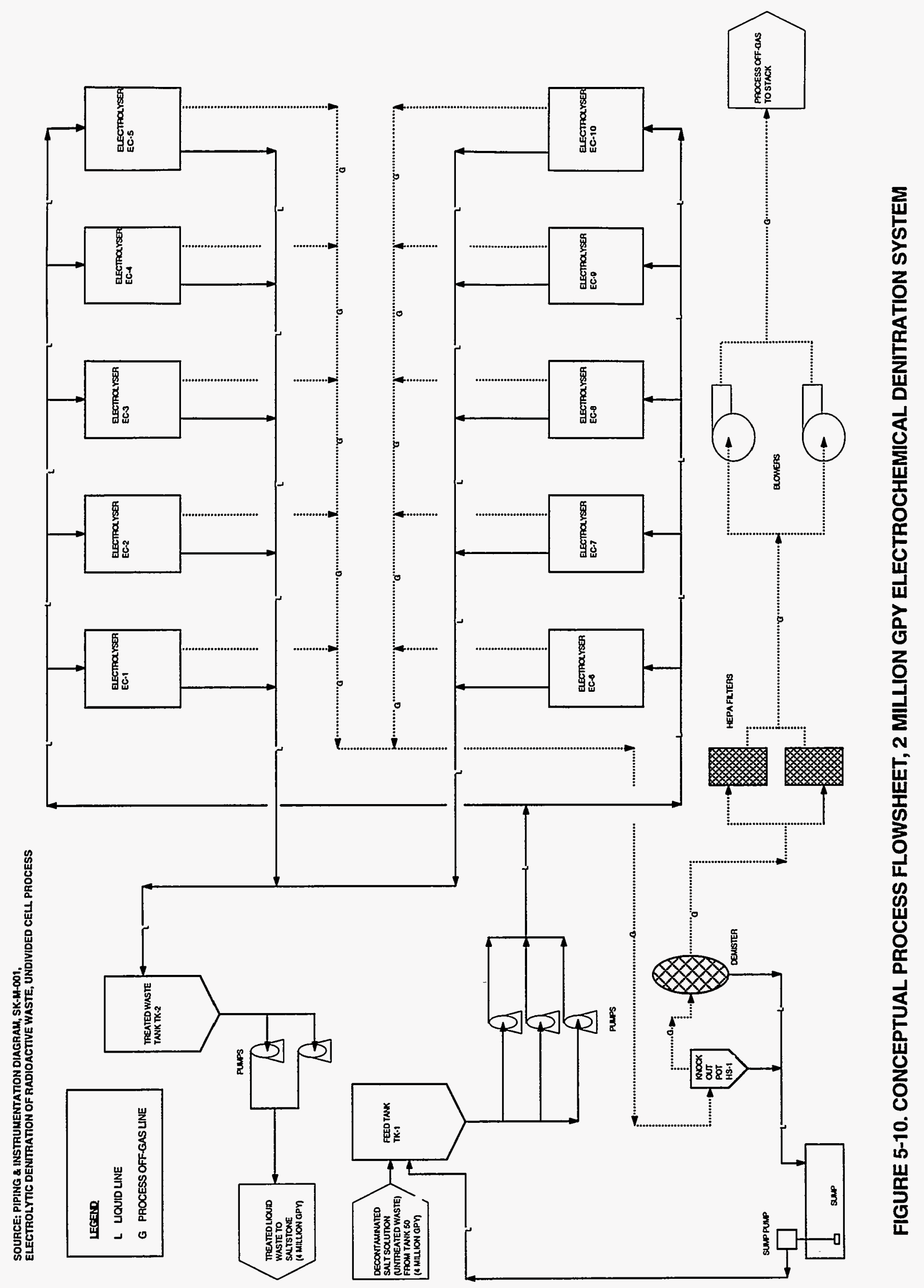


pumped through the electrolysers at a rate of $300 \mathrm{gpm}$ per electrolyser for processing. Separation of the gases from the liquid would be facilitated by oversized piping on the electrolyser outlets and a knock-out pot (HS-1).

The electrolyte that exits the electrolysers would be piped directly to Tank TK-2, where it would be sampled and held pending analysis. If the analysis shows that nitrate levels have been reduced to acceptable levels, the treated waste would be pumped from Tank TK-2 to the existing Saltstone Processing Facility for solidification and disposed of in on-site vaults.

During electrochemical processing, one mole of sodium hydroxide would be produced at the anode for each mole of nitrate that is destroyed at the cathode. In cases where the nitrate feed is concentrated, the hydroxide concentration in the treated liquid would exceed the Saltstone waste acceptance criterion of $4 \mathrm{M}$. To address this issue, the preconceptual design prepared by Bechtel must be modified to include a sodium hydroxide recovery step, as shown on Figure 5-11. The recovered sodium hydroxide could then be either reused on-site as a chemical reagent or sold as a commodity chemical to off-site consumers.

In the upgraded preconceptual design, the process off-gas would flow from the knock-out pot through a bank of HEPA filters and blowers before being discharged to the atmosphere through the process exhaust stack.

The process flowsheet prepared by Bechtel shows the off-gas system to consist primarily of a demister and HEPA filters. This aspect of the preconceptual design probably would not comply with air emission restrictions because it provides no abatement for discharges of ammonia gas. It is likely that a more rigorous off-gas treatment system that includes an ammonia burner or dissociator would be required if the electrochemical process is constructed at the SRS. This modification is also shown on Figure 5-11.

\subsubsection{Technical Evaluation}

The major advantages and disadvantages associated with this technology are discussed in Sections 5.4.2.1 and 5.4.2.2, respectively. The ability of the technology to meet the performance standards discussed in Section 3.4 is summarized in Section 5.4.2.3. The maturity of the technology and outstanding research and development needs are discussed in Section 5.4.2.4.

\subsubsection{Major Advantages}

Several major advantages associated with this technology include:

- The electrolysis of the nitrate-bearing alkaline waste streams could be accomplished without the addition of chemicals or other pretreatment.

- The process could be used on both alkaline and acidic waste streams.

- The potential exists to simultaneously destroy organic compounds in the waste streams at 


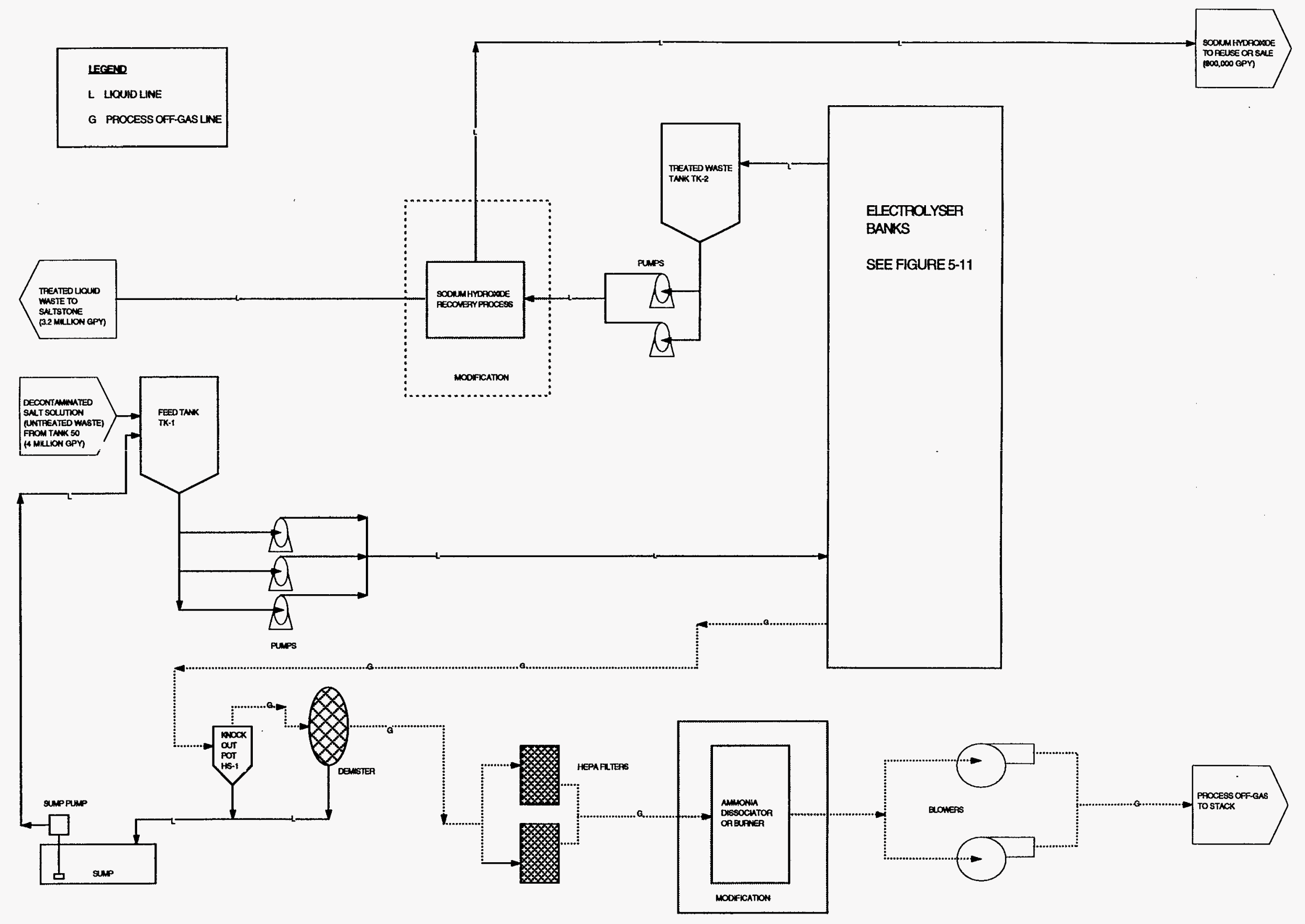

FIGURE 5-11. MODIFIED PROCESS FLOWSHEET, 2 MILLION GPY ELECTROCHEMICAL DENITRATION SYSTEM 
Rev. 0, 8/29/97

the anode while nitrates are being destroyed at the cathode.

\section{$\mathbf{5 , 4 , 2 , 2}$ Major Disadvantages}

The major disadvantages associated with this technology include the following:

- The electrolysis of nitrates would produce flammable and toxic ammonia gas that would require treatment prior to atmospheric discharge.

- Hydrogen produced at the cathode would present an explosion hazard.

- Sodium hydroxide would be produced at the anode. In cases where high concentrations of sodium hydroxide are produced, separation of the sodium hydroxide from the liquid stream may be needed to ensure the integrity of the final waste form. The waste acceptance criteria for the Saltstone facility would restrict the hydroxide content of feed streams to $4 \mathrm{M} .^{35}$

- Metals, including some radionuclides, dispersed in the wastes to be treated may plate out on the electrodes and reduce the electrolysis efficiency.

- Because of the metal and radionuclide plating problem, some criticality concerns may be associated with this technology.

- The product of electrolysis (treated liquid waste) would not be suitable for direct disposal and would have to be treated further (i.e., solidified in Saltstone). The use of Saltstone would increase the overall waste volume and final disposal costs by approximately $40 \%$.

\section{4 .23 Potential to Meet Performance Standards}

The applicable performance standards were previously described in Section 3.4. An evaluation of this technology's ability to satisfy these performance standards is presented below.

\section{Nitrate/Nitrite Destruction and Separation Efficiency}

The electrochemical process would be capable of meeting the performance standard for nitrate and nitrite destruction. Testing on SRS waste streams has shown that destruction efficiencies in excess of $99 \%$ can be achieved for nitrates and nitrites. Final catholyte concentrations of nitrate below

${ }^{35}$ Westinghouse Savannah River Corporation, "WSRC 1S Waste Acceptance Criteria Manual, Procedure 4.01, Acceptance Criteria for Aqueous Waste Sent to the Z-Area Saltstone Production Facility," Rev. No. 1, May 30, 1997. 
Rev. 0, 8/29/97

$0.1 \mathrm{M}$ have been achieved. ${ }^{36}$

\section{Worker Safety Standards}

Electrolysis has been used safely by industry in other applications for over a century. All applicable worker safety standards, including those specified in DOE Order 5480.1A, could be satisfied. The electrochemical process would use large amounts of electricity and pose significant electrical hazards to personnel. Electrical hazards could be effectively mitigated, however, by proper design and adherence to standard operating procedures.

\section{Process Safety Standards}

An electrochemical process for treating the decontaminated salt solution would probably be classified as a low or moderate hazard facility. A safety analysis report would be required before start-up. It is reasonable to conclude that an electrochemical process can be constructed and operated to meet or exceed all applicable process safety standards.

Electrolysis would require rigorous engineering controls to mitigate process hazards. The electrochemical treatment of nitrates would result in the evolution of significant quantities of ammonia and hydrogen gases. Ammonia gas is both flammable and toxic. Hydrogen gas is flammable.

\section{Radiological Safety Standards}

The electrochemical process could be designed and operated to meet all applicable radiological safety standards, including ALARA considerations. Process equipment would have to be designed to minimize exposures to O\&M personnel. Shielding may be required around certain process areas (i.e., electrolysers).

\section{Environmental Standards}

The electrochemical process would be capable of meeting all applicable environmental standards. The treatment process liquid residuals would be solidified in Saltstone and would meet applicable environmental standards, including the Saltstone waste acceptance criteria and the land disposal restrictions of RCRA. The treatment process gaseous emissions would contain high-levels of ammonia that could probably be effectively abated using commercially available air pollution control equipment. The electrochemical process would not produce liquid wastes that must be discharged to surface waters and, therefore, would not directly affect surface water quality.

${ }^{36}$ Hobbs, D. T., "Electrolytic Denitration of Radioactive Savannah River Site Waste," WSRC-TR-95-0176, April 26, 1995. 
Rev. 0, 8/29/97

\subsubsection{Technology Maturity and Research and Development Needs}

The electrochemical process for treating nitrate and nitrite containing mixed wastes has been studied for many years. Bench-scale and pilot-scale testing using actual and simulated wastes have been completed, as previously described.

The bench- and pilot-scale tests indicate that the electrochemical process may be a viable alternative for treating nitrate- and nitrite-bearing mixed waste streams at the SRS, achieving nearly complete nitrate/nitrite destruction and high electrolysis efficiencies.

There remain, however, substantial research and development needs. In particular, the generation and abatement of ammonia gas would require additional research to baseline the ammonia production rates in an industrial-scale process and to develop an effective ammonia abatement system. The process flowsheet prepared by Bechtel is believed to be deficient in these regards. ${ }^{37}$

Also, given the uncertainties regarding the production and abatement of ammonia gas, the capital and O\&M costs of an industrial-scale electrochemical process are not completely understood at this time.

\subsubsection{Evaluation of Costs}

Section 5.4.3.1 discusses the capital costs of the electrochemical waste treatment system. O\&M costs are discussed in Section 5.4.3.2. D\&D costs are estimated in Section 5.4.3.3. Life-cycle costs, computed on the basis of the capital, O\&M, and D\&D costs, are discussed in Section 5.4.3.4.

\subsubsection{Capital Cost}

The Westinghouse Savannah River Company (WSRC) Engineering and Construction Services Division has prepared a line-item cost estimate corresponding to the preconceptual design prepared by Bechtel (see Attachment 1). This cost estimate, which includes a $30 \%$ management reserve, establishes the capital cost of the 2 million gpy denitration system at $\$ 23,024,000$.

The addition of electrolyser cells and the upgrading of pumping systems will increase the capital costs. As shown in Table 5-11, RCS estimates the capital cost for a 4 million gpy electrochemical plant to be $\$ 22.55$ million.

\section{$\mathbf{5 , 4 , 3 , 2}$ Operation and Maintenance}

WSRC has not performed a formal estimate of the O\&M costs for the denitration system. However, the University of South Carolina recently determined that the electrical power

${ }^{37}$ Personal Communication between David Hobbs, Savannah River Technology Center, and Michael Navetta, RCS, June 30, 1997. 


\begin{tabular}{|c|c|c|}
\hline \multicolumn{3}{|c|}{ Table 5-11. Electrochemical System Capital Cost Estimate (1997 Dollars) } \\
\hline Item & Size & Cost, $\$$ \\
\hline Feed Tanks (2) & 20,000 gallons each & $170,000^{\mathrm{a}}$ \\
\hline Chemical Flush Tank & 5,000 gallons & $55,000^{b}$ \\
\hline Knock-out Pot & & $10,500^{b}$ \\
\hline Feed Tank Pumps (2) & $3000 \mathrm{gpm}, 300 \mathrm{ft}$. head & 180,000 \\
\hline Miscellaneous Pumps & & 20,000 \\
\hline Demister & & $7,700^{b}$ \\
\hline Electrolysers (10) & ICI FM 21 & $1,500,000$ \\
\hline HEPA Filter (2) & & $28,000^{\mathrm{b}}$ \\
\hline Subtotal, Major Equipment & & $1,970,000$ \\
\hline $\begin{array}{l}\text { Miscellaneous Equipment @ 30\% } \\
\text { of Major Equipment }\end{array}$ & & 590,000 \\
\hline $\begin{array}{l}\text { Equipment Installation, } 50 \% \text { of } \\
\text { Major Equipment }\end{array}$ & & 990,000 \\
\hline Facilities@ @ $\$ 200 / \mathrm{ft}^{2}$ & & $12,000,000$ \\
\hline $\begin{array}{l}\text { Subtotal, Installed Equipment } \\
\text { and Facilities }\end{array}$ & & $15,550,000$ \\
\hline Engineering, $15 \%$ & & $2,330,000$ \\
\hline Management Reserve, $30 \%$ & & $4,670,000$ \\
\hline Total & & $22,550,000$ \\
\hline \multicolumn{3}{|c|}{$\begin{array}{ll}\text { Notes } & \\
\text { a } & \text { Verbal quotations from John Wood Co., Valley Forge, PA, and Dal-Worth Fabrication } \\
\text { Inc., Grand Prairie, TX. } \\
\text { b } & \text { Taken from Bechtel preconceptual cost estimate. }\end{array}$} \\
\hline
\end{tabular}

requirements for the 2 million gpy denitration system designed by Bechtel would be 17.2 million 
$\mathrm{kWh} / \mathrm{yr} .{ }^{38}$ At a power consumption rate of 34.4 million $\mathrm{kWh} / \mathrm{yr}$ and a unit cost of $\$ 0.057$ per $\mathrm{kWh}$, the cost of electricity for a nominal 4 million gpy system would be approximately $\$ 2,000,000$ per year.

It is estimated that the operation of the electrochemical process would require two chemical operators and a supervisor on each shift. Corresponding annual labor costs are estimated to be $\$ 780,000$.

Total O\&M costs have been estimated by RCS to be approximately $\$ 3.97$ million per year, as listed in Table 5-12. At a processing rate of 4 million gpy, these costs apportion to $\$ 0.99$ per gallon of alkaline waste treated.

\begin{tabular}{|c|c|c|c|}
\hline \multicolumn{4}{|c|}{$\begin{array}{l}\text { Table 5-12. Annual O\&M Costs, } \\
\text { Electrochemical Denitration System }\end{array}$} \\
\hline O\&M Item & Units & Unit Cost, & Extension, $\$$ \\
\hline $\begin{array}{l}\text { Direct Labor (Fully Burdened) - } \\
\text { Operators }\end{array}$ & 8 & 60,000 & 480,000 \\
\hline $\begin{array}{l}\text { Direct Labor (Fully Burdened) - } \\
\text { Shift Supervisors }\end{array}$ & 4 & 75,000 & 300,000 \\
\hline Process Electricity & 34.4 million $\mathrm{kWh}$ & 0.057 & $2,000,000$ \\
\hline $\begin{array}{l}\text { Support Utilities - HVAC, } \\
\text { lighting, potable water, sewer }\end{array}$ & 1 lot & 60,000 & 60,000 \\
\hline $\begin{array}{l}\text { Process Maintenance ( } 5 \% \text { of } \\
\text { Capital Cost) }\end{array}$ & 1 lot & & $1,130,000$ \\
\hline Total & & & $3,970,000$ \\
\hline
\end{tabular}

\section{5,4,3.3 Decontamination and Decommissioning Costs}

An estimate of the D\&D costs has not been prepared by WSRC. Consistent with guidelines used in previous sections of this report, the author estimates the D\&D costs to be $\$ 30$ million.

\subsubsection{Life-Crcle Costs}

For the purpose of estimating the present value of the total life-cycle cost for the electrochemical

${ }^{38}$ Letter from John W. Van Zee (University of South Carolina) to David Hobbs (SRTC), December 27, 1996. 
Rev. 0, 8/29/97

denitration system, the same assumptions described in Section 5.1.3.4 of this report were made. The present value of the life-cycle costs is estimated to be approximately $\$ 325$ million, as listed in Table 5-13.

\begin{tabular}{|c|l|l|}
\hline \multicolumn{2}{|c|}{ Table 5-13. Present Value of Electrochemical Denitration System Life-Cycle Costs } \\
\hline Capital Cost (2000 dollars) & \multicolumn{1}{|c|}{ Cost, \$ } & \multicolumn{1}{c|}{ Present Value, $\$$} \\
\hline RCRA Permit & $52,550,000$ & $22,550,000$ \\
\hline NEPA Documents & 100,000 & 500,000 \\
\hline O\&M Cost & & 100,000 \\
\hline Year 1 & $3,970,000$ & \\
\hline Total, Years 1 - 25 & $165,330,000$ & $60,610,000$ \\
\hline Residue Disposal & & \\
\hline Year 1 & & \\
\hline Total, Years 1 - 25 & $15,552,000$ & $237,451,000$ \\
\hline D\&D Cost (2023 Dollars) & $347,700,000$ & $3,760,000$ \\
\hline Total & $\mathbf{8 6 6 , 1 8 0 , 0 0 0}$ & $\mathbf{3 2 4 , 9 7 1 , 0 0 0}$ \\
\hline $\begin{array}{l}\text { Notes } \\
\text { a }\end{array}$ & & \\
\hline \begin{tabular}{l} 
Assumes disposal of 3.2 million gallon of liquid per year in Saltstone at a unit cost of \\
\hline
\end{tabular} & & \\
\hline
\end{tabular}

\subsubsection{Other Considerations}

Several other considerations may impact the viability of the technology. These include the implementation schedule, secondary waste streams, pollution prevention, public acceptance, and regulatory permitting. Each is discussed in the ensuing sections of this report.

\subsubsection{1 - Implementation Schedule}

The requirement to denitrate the alkaline wastes is short-term. To be viable for this application, the technology should be capable of (1) being implemented in a reasonably short period of time (i.e., less than 5 years) and (2) eliminating the anticipated inventory of 92 million gallons of alkaline waste at the SRS in 25 years or less.

Assuming a conventional technology development and procurement approach will be used and 
funding will be available, it is estimated that a full-scale electrochemical process could be operational in 6 years. Approximately 2 years would be required to prepare the final engineering design. Regulatory permitting would also need to be completed during this 2-year period.

Thereafter, the design, construction, and systemization of the electrochemical treatment system could be completed in 3 to 4 years. As stated previously, privatization may afford an opportunity to reduce this lead time below 5 years.

At a processing rate of 4 million gpy, the system should be capable of eliminating the inventory of alkaline nitrate-bearing mixed waste at the SRS in less than 25 years.

\subsubsection{Secondary Waste Streams}

To the extent possible, the treatment system should not produce large quantities of highly toxic secondary waste streams that would require treatment prior to disposal.

Two secondary waste streams are produced during the electrolysis of nitrates. The first is process off-gas containing hydrogen and ammonia. The second is electrode cleaning solution consisting of a mixture of acids, metals, and radionuclides. Both of these waste streams would be produced in substantial volume and would require treatment. The required treatment could probably be affected using conventional technologies, however.

\section{4,4.3 Pollution Prevention}

By reducing the nitrate content of the treated waste, electrolysis would reduce the toxicity and leachability of the final waste form (Saltstone). The use of Saltstone, however, would have the adverse effect of increasing the overall waste volume and final disposal costs by $40 \%$.

\subsubsection{Public Acceptance}

Electrolysis has not been widely publicized, and there is no organized opposition to electrolysis from environmental or citizens groups. All indications are that the selection of electrochemical processing for the decontaminated salt solution task would receive public support.

\subsubsection{5_Regulatory Permitting}

The electrochemical process would require a RCRA Part B permit and an air pollution permit from the South Carolina Department of Health and Environmental Control. These permits would be relatively easy to acquire and would be much less expensive than the permits required for the Consolidated Incineration Facility (CIF). The permitting process could be competed in 12 to 24 months.

\subsubsection{Versatility}

The electrochemical process has been demonstrated to be capable of destroying organics in radioactive, mixed, and hazardous wastes. The process is more versatile than NAC but less 
Rev. 0, 8/29/97

versatile than the thermal and hydrothermal alternatives.

\subsection{EVALUATION OF ALTERNATIVE TECHNOLOGIES FOR NITRATE AND NITRITE DESTRUCTION AND SEPARATION}

Section 5 briefly described the technical and economic merits of several treatment alternatives. Table 6-1 summarizes the information that was presented.

\subsection{EVALUATION METHODOLOGY}

RCS employed a two-step evaluation process to systematically assess the relative technical and economic merits of the treatment alternatives. In Step 1, technologies that could not reasonably be expected to meet the following performance standards were eliminated. In Step 2, the remaining technologies were ranked on the basis of economic and other considerations. Ranking was based on the assignment of numerical scores using the Delphi technique, as shown in Table 6-2.

\subsection{TECHNOLOGY RANKING}

Using the evaluation methodology described above, RCS scored and ranked the alternatives as shown in Table 6-3. The NAC process achieved the highest ranking. The ranking hierarchy of the technologies, in descending order of attractiveness, was as follows:

$\begin{array}{ll}\text { - } & \text { NAC } \\ \text { - } & \text { Vitrification } \\ \text { - } & \text { Electrochemical } \\ \text { - } & \text { Hydrothermal } \\ \text { - } & \text { Steam Reforming } \\ \text { - } & \text { Plasma Arc }\end{array}$

\subsection{UNCERTAINTY ANALYSIS}

Much work remains to be done in developing the denitration technologies investigated for this report. Full-scale flowsheets encompassing both the waste processing and off-gas and residuals treatment systems have not been completed. Accordingly, there remain significant uncertainties with regards to treatment efficacy and mass and energy balances. These technical uncertainties, in turn, impart uncertainties to the cost analyses reported in the previous sections.

The disposal costs for process residues from plasma arc, vitrification, and NAC were predicated on those residues being delisted from RCRA Subtitle $\mathrm{C}$ regulation and disposed of as low-level wastes at significant savings over disposal as mixed wastes. The delisting process is highly 


\begin{tabular}{|c|c|c|c|c|c|c|}
\hline 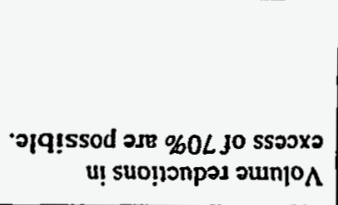 & 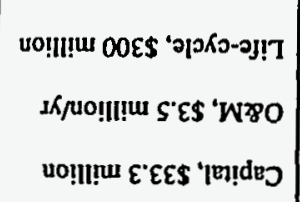 & 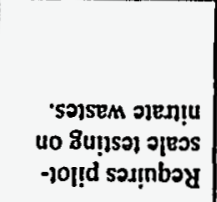 & so $\mathrm{X}$ & 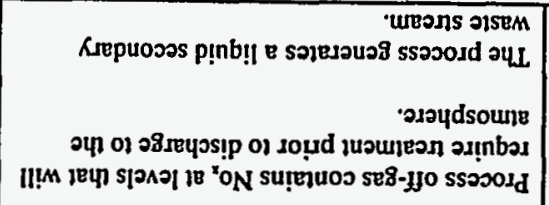 & 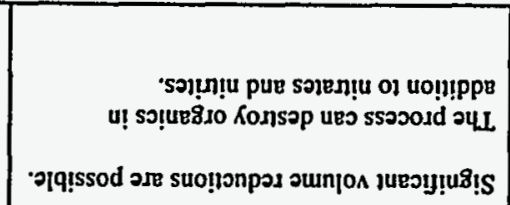 & 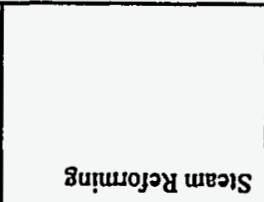 \\
\hline 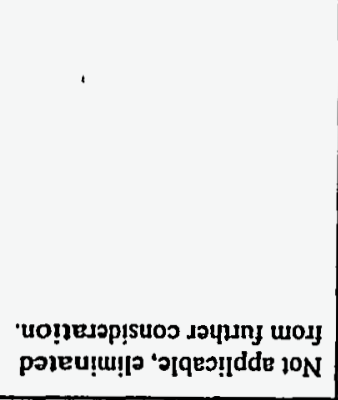 & 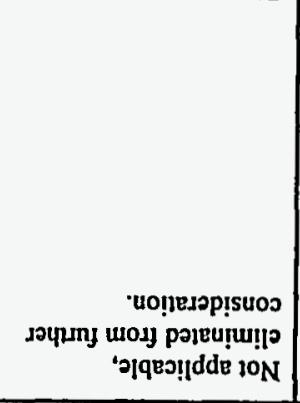 & 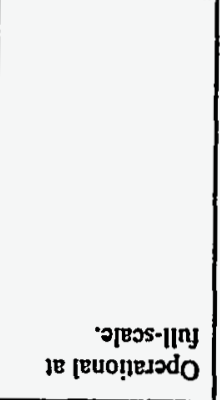 & ON & 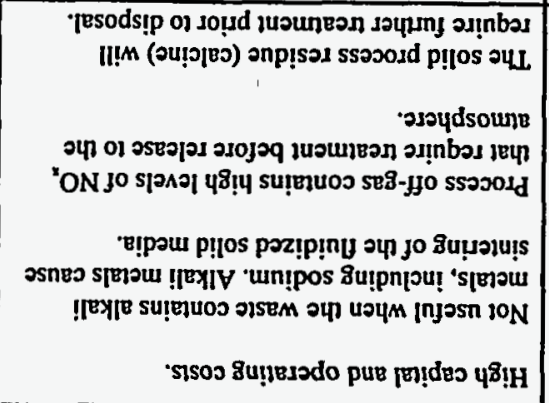 & 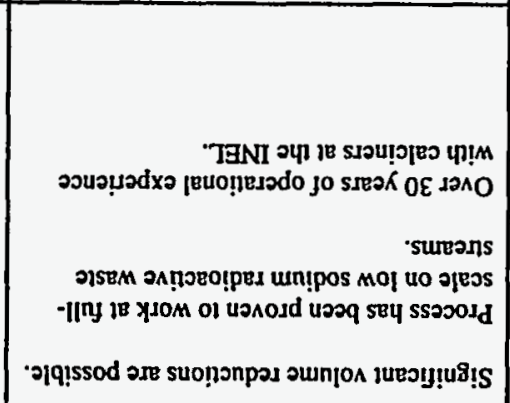 & 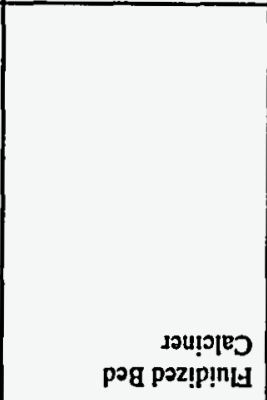 \\
\hline 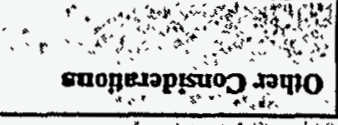 & 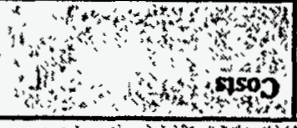 & 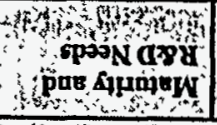 & 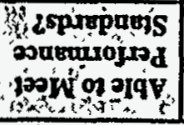 & 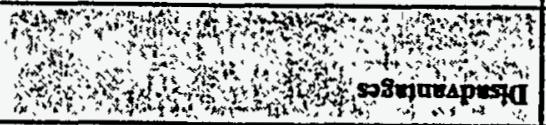 & 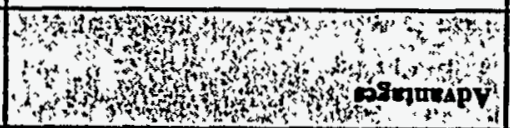 & as \\
\hline
\end{tabular}




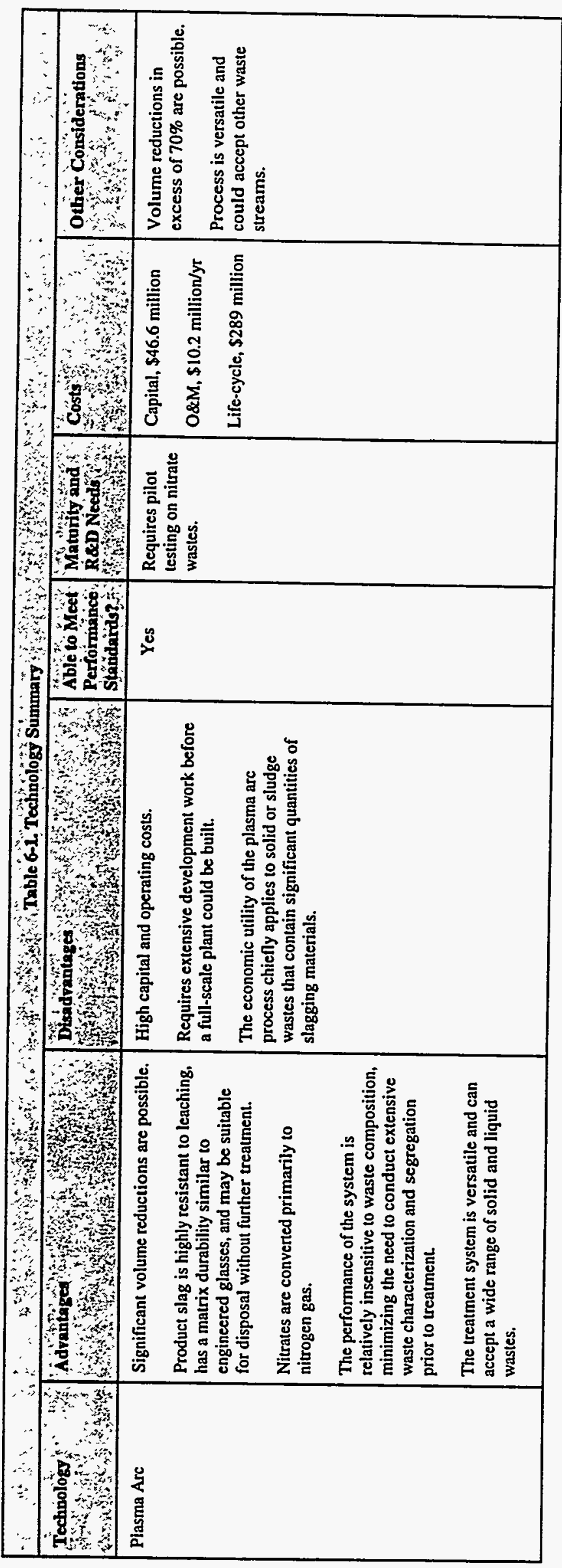




\begin{tabular}{|c|c|c|c|c|c|c|}
\hline 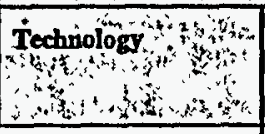 & Advantaged & 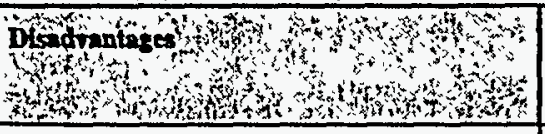 & $\begin{array}{l}\text { Able to Meet? } \\
\text { Performance. } \\
\text { Standdarda? }\end{array}$ & $\begin{array}{l}\text { Maturity and } \\
\text { R\&D Neds } \\
\text { Yop }\end{array}$ & Costs, & Other Consterations \\
\hline Electrochemical & $\begin{array}{l}\text { Waste feeds would not require } \\
\text { pretreatment. } \\
\text { The process could be used on both acidic } \\
\text { and alkaline wastes. } \\
\text { The potential exists to destroy organics in } \\
\text { the waste. }\end{array}$ & $\begin{array}{l}\text { Electrolysis would produce flammable and } \\
\text { loxic off-gas that would require treatment. } \\
\text { The product of hydrolysis would require } \\
\text { stabilization prior to disposal. } \\
\text { The electrochemical process would produce } \\
\text { sodium hydroxide that may have to be } \\
\text { separated from the product stream before } \\
\text { stabilization and disposal. }\end{array}$ & Yes & $\begin{array}{l}\text { Some pilot-scale } \\
\text { work is needed } \\
\text { to refine the } \\
\text { process } \\
\text { flowsheet. }\end{array}$ & $\begin{array}{l}\text { Capital, \$22.6 million } \\
\text { O\&M, \$4 million/yr } \\
\text { Life-cycie, \$325 million }\end{array}$ & $\begin{array}{l}\text { Electrochemical processing } \\
\text { followed by stabilization in } \\
\text { Saltstone leads to an } \\
\text { overall } 40 \% \text { increase in } \\
\text { waste volume. }\end{array}$ \\
\hline
\end{tabular}




\begin{tabular}{|c|c|c|c|c|c|c|}
\hline 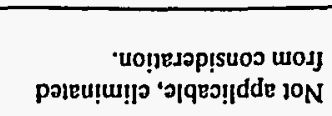 & 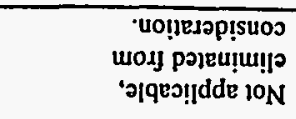 & $\begin{array}{l}\text { uo!nesop!suos } \\
\text { uoy pajeu!uu!| } \\
\text { 'गqeग!dde 10N }\end{array}$ & oN & 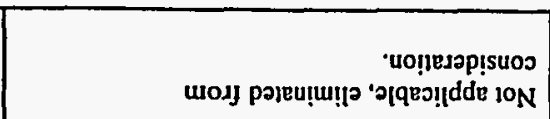 & 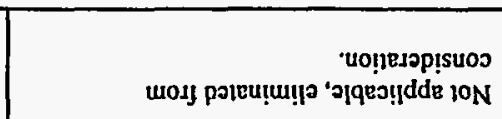 & 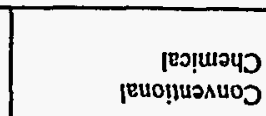 \\
\hline 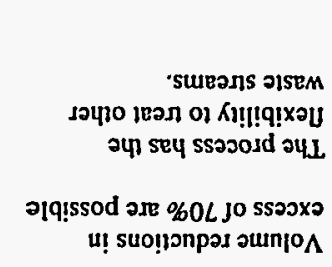 & 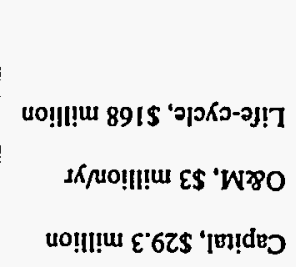 & $\begin{array}{r}\text { 'papasu әq } \\
\text { II!M su!pso 10!! }\end{array}$ & so $\mathrm{X}$ & 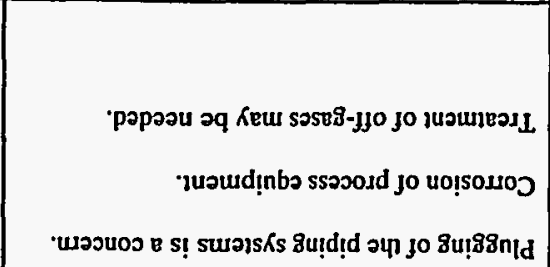 & 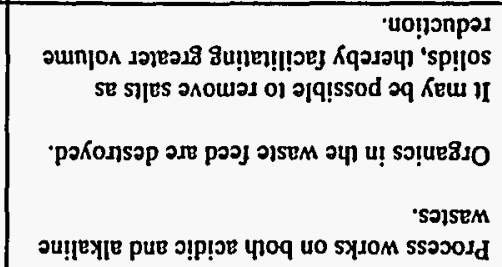 & ןeш⿻иро $p \Omega_{H}$ \\
\hline 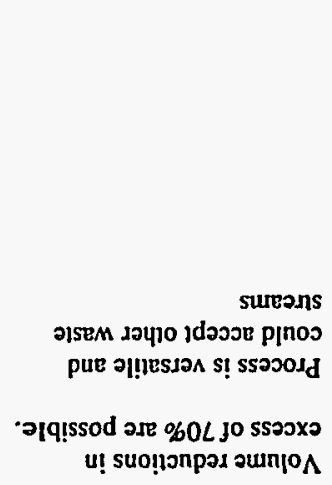 & 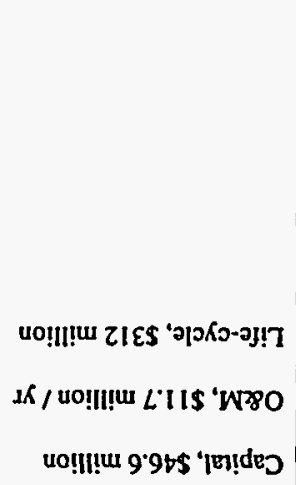 & 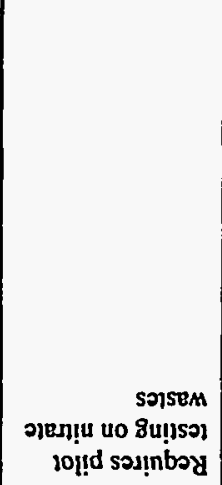 & SOX & 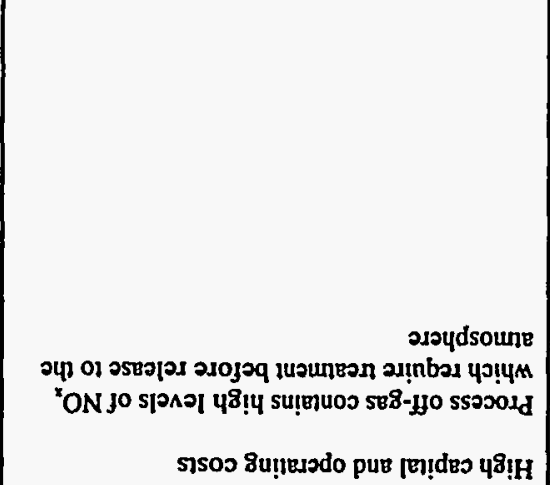 & 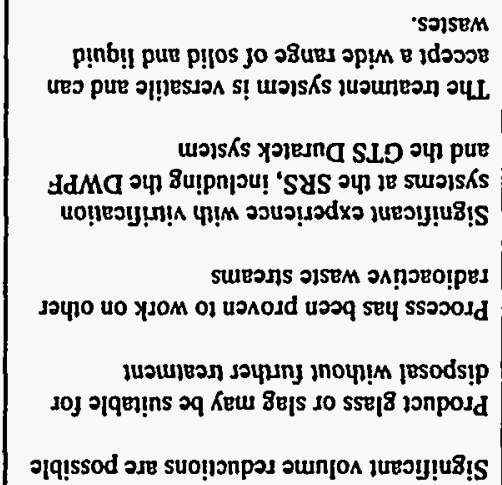 & 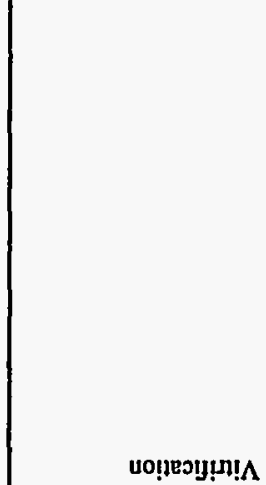 \\
\hline 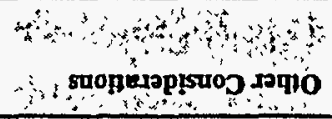 & 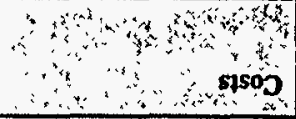 & 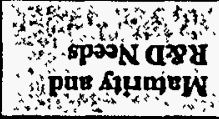 & 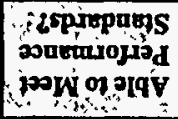 & 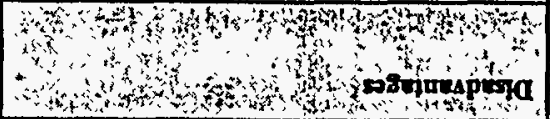 & 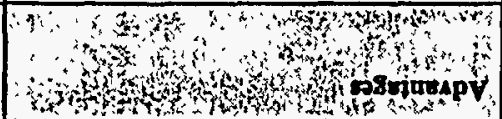 & 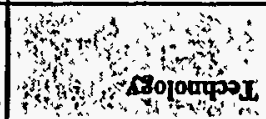 \\
\hline
\end{tabular}




\begin{tabular}{|c|c|}
\hline \multicolumn{2}{|r|}{ Table 6-2. Scoring System } \\
\hline Consideration & Score \\
\hline $\begin{array}{l}\text { Destruction/Separation } \\
\text { Efficiency }\end{array}$ & $\begin{array}{l}\text { If }>90 \% \text {, score is } 1 \text {. If }<90 \% \text {, total score is } 0 \text { and technology is } \\
\text { eliminated. }\end{array}$ \\
\hline $\begin{array}{l}\text { Worker Protection, } \\
\text { Radiological, and Process } \\
\text { Safety Standards }\end{array}$ & $\begin{array}{l}\text { If able to meet all, score is } 1 \text {. If unable to meet any, total score } \\
\text { is } 0 \text { and technology is eliminated. }\end{array}$ \\
\hline $\begin{array}{l}\text { Environmental Protection } \\
\text { Standards }\end{array}$ & $\begin{array}{l}\text { If able to meet all, score is } 1 . \text { If unable to meet any, total score } \\
\text { is } 0 \text { and technology is eliminated. }\end{array}$ \\
\hline Technology Maturity & $\begin{array}{l}\text { Score is } 0 \text { if not tested using nitrate wastes. } \\
\text { Score is } 1 \text { if bench-scale tested using nitrate wastes. } \\
\text { Score is } 5 \text { if pilot-scale tested using nitrate wastes. } \\
\text { Score is } 10 \text { if engineering-scale tested using nitrate wastes. } \\
\text { Score is } 17 \text { if full-scale facility has treated nitrate wastes. }\end{array}$ \\
\hline Cost & $\begin{array}{l}\text { If present value of life-cycle cost }<\$ 150 \text { million, score is } 30 \text {. } \\
\text { If present value of life-cycle cost }>\$ 150 \text { million and }<\$ 250 \\
\text { million, score is } 20 \text {. } \\
\text { If present value of life-cycle cost }>\$ 250 \text { million and }<\$ 350 \\
\text { million, score is } 10 \text {. } \\
\text { If present value of life-cycle cost }>\$ 350 \text { million, score is } 0 \text {. }\end{array}$ \\
\hline Implementation Schedule & $\begin{array}{l}\text { If }<5 \text { years using conventional approach, score is } 5 \text {. } \\
\text { If privatization can be used to get to }<5 \text { years, score is } 3 \text {. } \\
\text { Otherwise, score is } 0 \text {. }\end{array}$ \\
\hline Secondary Waste Streams & $\begin{array}{l}\text { If significant quantities are produced, score is } 0 \text {. } \\
\text { Otherwise, score is } 5 \text {. }\end{array}$ \\
\hline
\end{tabular}


Rev. 0, 8/29/97

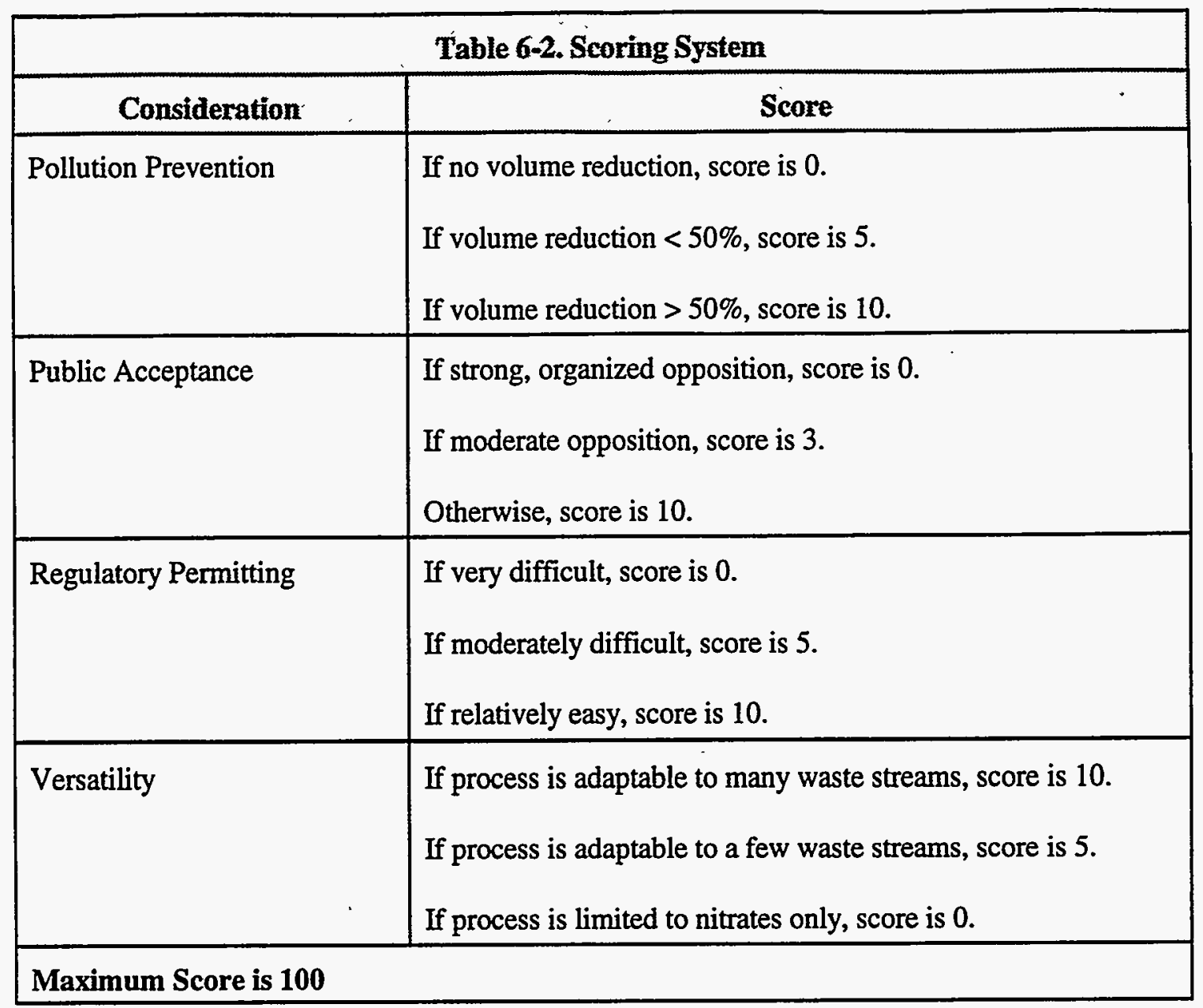




\begin{tabular}{|c|c|c|c|c|c|c|c|c|}
\hline \multicolumn{9}{|c|}{ Table 6-3. Technology Scoring } \\
\hline \multirow[t]{2}{*}{ Consideration } & \multicolumn{8}{|c|}{ Technology : } \\
\hline & $\begin{array}{l}\text { Fkuidized } \\
\text { Bed } \\
\text { Calciner }\end{array}$ & $\begin{array}{l}\text { Steam } \\
\text { Reformer }\end{array}$ & Plasma Arc & Vitrification & Hydrothermal & $\begin{array}{l}\text { Conventional } \\
\text { Chemical }\end{array}$ & NAC & Electrochemical \\
\hline $\begin{array}{l}\text { Destruction / Separation } \\
\text { Efficiency }\end{array}$ & 0 & 1 & 1 & 1 & 1 & $\mathbf{0}$ & 1 & 1 \\
\hline $\begin{array}{l}\text { Worker Protection, } \\
\text { Radiological, and } \\
\text { Process Safety Standards }\end{array}$ & & 1 & 1 & 1 & 1 & & 1 & 1 \\
\hline $\begin{array}{l}\text { Environmental } \\
\text { Protection Standards }\end{array}$ & & 1 & 1 & 1 & 1 & & 1 & 1 \\
\hline Technology Maturity & & 0 & 0 & 17 & 1 & & 1 & 17 \\
\hline Cost & & 10 & 10 & 10 & 20 & & 30 & 10 \\
\hline $\begin{array}{l}\text { Implementation } \\
\text { Schedule }\end{array}$ & & 3 & 3 & 3 & 3 & & 3 & 3 \\
\hline $\begin{array}{l}\text { Secondary Waste } \\
\text { Streams }\end{array}$ & & 5 & 5 & 5 & $\mathbf{0}$ & & 5 & 0 \\
\hline Pollution Prevention & & 10 & 10 & 10 & 5 & & 10 & 0 \\
\hline Public Acceptance & & 10 & 3 & 3 & 10 & & 10 & 10 \\
\hline Regulatory Permitting & & 10 & 5 & 5 & 10 & & 10 & 10 \\
\hline Versatility & & 5 & 10 & 10 & 5 & & 0 & 5 \\
\hline Total & $\mathbf{0}$ & 56 & 49 & 66 & 57 & $\mathbf{0}$ & 72 & 58 \\
\hline Rank & N/A & 5 & 6 & 2 & 4 & N/A & 1 & 3 \\
\hline
\end{tabular}


Rev. 0, 8/29/97

uncertain. Consequently, the disposal costs for these residues could increase substantially over those reported if delisting proves to be impracticable.

The ranking of the technologies is particularly sensitive to the life-cycle costs. The technology ranking was most strongly correlated to the O\&M and residue disposal costs. Given that the operating experience with these alternatives is limited, there is significant uncertainty in the O\&M and residue disposal costs.

To test the effects of this uncertainty on the ranking process, the O\&M and residue disposal costs for the top three alternatives were increased by $25 \%$ and those of the bottom three alternatives were reduced by $25 \%$. Life-cycle costs were then recomputed and the alternatives were rescored using the same methodology described in Table 6-2. The results, summarized in Table 6-4, indicate a much different selection hierarchy as follows:

- NAC

- Hydrothermal

- Steam Reforming

- Plasma Arc

- Vitrification

- Electrochemical

\subsection{CONCLUSIONS AND RECOMMENDATIONS}

The following technologies that were investigated by RCS appear to be capable of meeting the technical and procedural performance standards for the nitrate/nitrite treatment system to be constructed at the SRS:

- Electrochemical

- Steam reforming

- NAC.

- Hydrothermal

- Vitrification

- Plasma arc 


\begin{tabular}{|c|c|c|c|c|c|c|c|c|}
\hline \multicolumn{9}{|c|}{ Table 6-4. Uncertainty Analysis Scoring } \\
\hline \multirow[t]{2}{*}{ Consideration } & & \multicolumn{4}{|l|}{ Technology } \\
\hline & $\begin{array}{l}\text { Fluidized } \\
\text { Bed } \\
\text { Calciner } \\
\end{array}$ & $\begin{array}{l}\text { Steam } \\
\text { Reformer }\end{array}$ & Plasma Arc & Vitrification & Hydrothermal & $\begin{array}{l}\text { Conventional } \\
\text { Chemical }\end{array}$ & NAC & Electrochemical \\
\hline $\begin{array}{l}\text { Destruction/Separation } \\
\text { Efficiency }\end{array}$ & 0 & 1 & 1 & 1 & 1 & 0 & 1 & 1 \\
\hline $\begin{array}{l}\text { Worker Protection, } \\
\text { Radiological, and Process } \\
\text { Safety Standards }\end{array}$ & & 1 & 1 & 1 & 1 & & 1 & 1 \\
\hline $\begin{array}{l}\text { Environmental Protection } \\
\text { Standards }\end{array}$ & & 1 & 1 & 1 & 1 & & 1 & 1 \\
\hline Technology Maturity & & 0 & 0 & 17 & 1 & & 1 & 17 \\
\hline Cost & & 20 & 20 & 0 & 30 & & 30 & 0 \\
\hline Implementation Schedule & & 3 & 3 & 3 & 3 & & 3 & 3 \\
\hline Secondary Waste Streams & & 5 & 5 & 5 & 0 & & 5 & 0 \\
\hline Pollution Prevention & & 10 & 10 & 10 & 5 & & 10 & 0 \\
\hline Public Acceptance & & 10 & 3 & 3 & 10 & & 10 & 10 \\
\hline Regulatory Permitting & & 10 & 5 & 5 & 10 & & 10 & 10 \\
\hline Versatility & & 5 & 10 & 10 & 5 & & 0 & 5 \\
\hline Total & $\mathbf{0}$ & 66 & 59 & 56 & 67 & $\mathbf{0}$ & 72 & 48 \\
\hline Rank & N/A & 3 & 4 & 5 & 2 & N/A & 1 & 6 \\
\hline
\end{tabular}


The technologies that exhibit the most favorable economics are NAC, hydrothermal, and plasma arc. Considering other factors in addition to economics, such as implementation schedule, pollution prevention, and public acceptance, the ranking performed by RCS indicates the hierarchy of alternatives, in descending order of attractiveness, to be as follows:

- NAC

- Vitrification

- $\quad$ Electrochemical

- Hydrothermal

- $\quad$ Steam Reforming

- Plasma Arc

The ranking performed by RCS is most sensitive to life-cycle costs, especially O\&M costs. Increasing the life-cycle costs of the three most attractive alternatives by $25 \%$ while reducing the O\&M costs of the three least attractive alternatives by that same percentage has the effect of reordering the hierarchy as follows:

- NAC

- Hydrothermal

- $\quad$ Steam Reforming

- $\quad$ Plasma Arc

- $\quad$ Vitrification

- $\quad$ Electrochemical

For this reason, the life-cycle costs of the altematives should be more rigorously examined before the final technology is selected.

The other principal conclusions of this report are as follows:

- $\quad$ All of the technologies listed above would require extensive development before a fullscale process for treating SRS waste could be constructed and operated.

- The technical and economic feasibility of the NAC, vitrification, and electrochemical processes would be most attractive, relative to the other altematives investigated. 
- More robust treatment technologies, such as plasma arc or vitrification, are more versatile that the electrochemical, steam reforming, hydrothermal, and NAC processes and offer the ability to treat additional waste streams.

- Some type of privatization may be required to expedite the deployment of the selected technology.

- The ranking of the electrochemical is suppressed more than any other by high residue disposal costs. If the cost of Saltstone operations and final disposal could be reduced, the ranking of the electrochemical process would rise.

The electrochemical reduction process has been extensively tested on SRS waste streams and is more mature in this application than the other technologies. There remain significant uncertainties in the development of all of the technologies investigated; however, the uncertainties associated with electrochemical reduction are much smaller than those associated with the other technologies. 
Rev. 0, 8/29/97

ATTACHMENT 1. PRECONCEPTUAL COST ESTIMATE, ELECTROCHEMICAL DENITRATION AND CAUSTIC RECOVERY, PHASE I 
$-$.

- IfESTINGHOUSE SAVANNAH RIVER COMPANY UNE ITEM: PROJECTNO:

LOS NUMBER: 96-05-06, R/1

PROJECTNAME: ELECTOCHEMICAL DENITRATION \& CAUSTIC REC., PHASE I

LOCATION $1:$

PROS UAYAGER D,

ESTIMATE TYPE: PRE-CONCEPTUAL

SITEWBS: SITE WBS POST 94 RATES

PRICING:

\begin{tabular}{|c|c|c|c|}
\hline $\begin{array}{l}\text { WBS } \\
\text { ELEMENT }\end{array}$ & DESCRIPTION & HOURS & LABOR \\
\hline
\end{tabular}

HOURS

SITE PROJECT ESTIMATING

ESTIMATE SUMMARY LEVEL REPORT

TOTALESTIMATED COST TIEC)
ENGINEERING
CONSTRUCTION
PROJECT SUPPORT

ESCALATION FOR TOTAL ESTIMATED COST (TEC) TOTALESTIMATED COST (TEC) SUBTOTAL

FY 97 G \& A RATE $@ 22.00 \%$ AND APPLIED TO $100.00 \%$ OF ALL TOTA

SUBTOTAL WITHOUT CONTINGENCY

MANAGEMENT RESERVE @ $30.00 \%$

$\begin{array}{lll}31,818 & \$ 2,033,189 & \$ 2,033,189\end{array}$

$\begin{array}{lllllll}104,853 & \$ 3,767,923 & \$ 678,897 & \$ 1,910,462 & \$ 2,175,000 & \$ 1,394,748 & \$ 9,927,030\end{array}$

$\begin{array}{lll}19,732 & \$ 1,394,033 & \$ 1,394,033\end{array}$

\begin{tabular}{llllll}
565,199 & 65,853 & 185,315 & 210,975 & 135,291 & $1,162,632$ \\
\hline
\end{tabular}

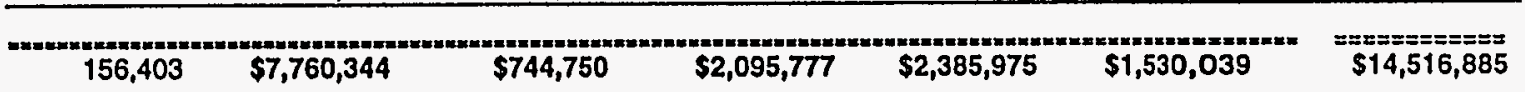

CONTINGENCY @ $0.00 \%$

PROJECT TOTAL COST

\begin{abstract}
APPROVAL SIGNATURES
\end{abstract}
TPC PROJECT MANAGER

DATE

CONSTRUCTION

DATE

PROJECT ENGINEERING MANAGER (PEM)

DATE

ESTIMATING MANAGER

DATE

ESTIMATOR

PEER

LEAD

DATE 


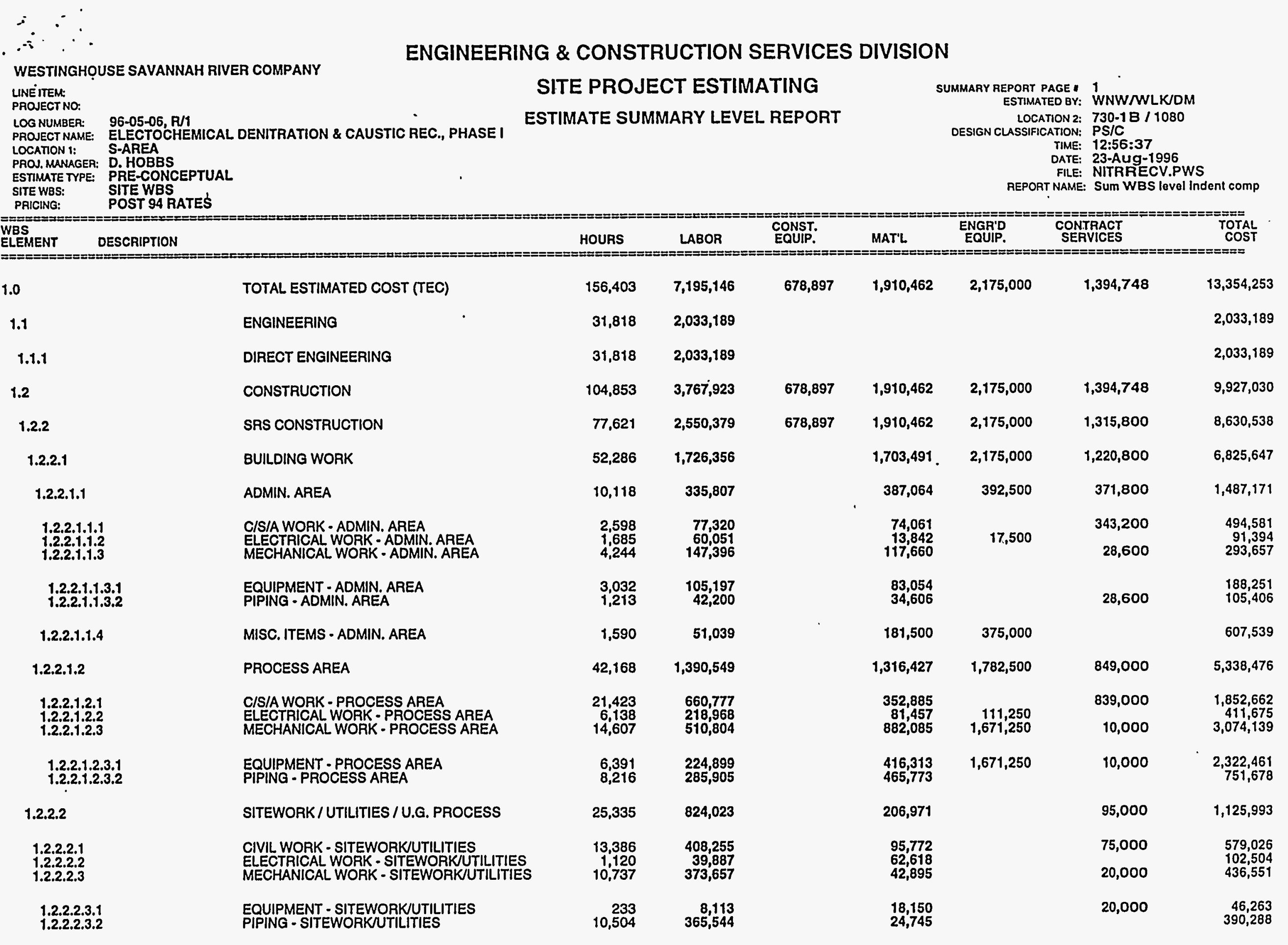


$\therefore$

WESTINGHOQUSE SAVANNAH RIVER COMPANY

UNE ITEM:

PROJECTNO:

LOG NUMBER: 96-05-06, R/1

ENGINEERING \& CONSTRUCTION SERVICES DIVISION

LOCATION 1:

PROJ. MANAGEA: D. HOBBS

PSTMATE TYPE: PRE-CONCEPTUAL

SITE WBS:
PRICING:

SITE PROJECT ESTIMATING

ESTIMATE SUMMARY LEVEL REPORT
SUMMARY REPORT PAGE " 2

ESTIMATED BY: WNWNLKJDM

LOCATION 2: $730-1 B / 1080$

DESIGN CLASSIFICATION: PS/C

TIME: 12:56:37

DATE: 23-Aug-1996

FILE. NITRRECV PWS

REPORT NAME. SUm WBS lovel indent comp

$=2=\pi=================$

WBS

HOURS

LABOR

CONST.

MATL

ENGR'D

CONTRACT

COTAL

1.2.2.2.3.2.1

1.2.2.2.4

1.2.2.3

1.2 .3

1.2.3.1

1.2.3.9

1.2 .4

1.4

1.4.1

4.

1.4 .3
1.4 .4
COREJJKT. WASTE TRANSFER LINE - SITEWORK

10,320

FIRE PROTECTION PIPING - SITEWORK

MISC. ITEMS - SITEWORKIUTILITIES

BEMCAP

CONTRACT ADMINISTRATION / CRAFT SUPPORT / 12,419 OTHER

359,125

2,576

3,843

\section{8,392}

1,906
4,447

5,687

91

2,224

373,821

CONTRACT ADMIN. / COST DISTR. / OTHER CRAFT SUPPORT

$12,419 \quad 373,821$

CONSTRUCTION NONMANUAL

14,813

843,723

$19,732 \quad 1,394,033$

PROJECT SUPPORT

$\begin{array}{ll}8,216 & 637,562 \\ 4,562 & 299,661\end{array}$

299,661
99,887

$5,433 \quad 356,923$
PROJECT CONTROLS DESIGN ENGINEERING

PAOJECT CONTROLS CONSTRUCTION
377,517 4,482 8,290

7,911

678,897

78,948

452,769

78,948

78,948 373,821

843,723

$1,394,033$

637,562

299,661

99,887
356,923 
$\therefore \quad$.

- WESTINGHOUSE SAVANNAH RIVER COMPANY PRÖJECT NO.: LNEITEM:

LOQ NUMBER: 96-05-06, R/1

LOCATION 1: S-AREA

PROJ. MANAGER D. HOBBS

ESTMMATE TYPE: PRE-CONCEPTUAL

SITE WBS: SITE WBS

WBS 1

POST 94 RATES

DETAIL LINE ITEM REPORT

SITE PROJECT ESTIMATING
PROAECT NAME: ELECTOCHEMICAL DENITRATION \& CAUSTIC R̀EC., PHASEI

DESCRIPTION

QUANTITY UOM

HOURS

HOURS
ADJST

LABOR

EQUIP.

MAT'L

PAGE" 2

ESTIMATED QY: WNWNLK/DM

LOCATION 2: 730-1B/1080

DESIGN CLASSIFICATION: PS/C

$$
\begin{aligned}
& \text { TIME: } 12: 56: 08 \\
& \text { DATE } 23-A U g-1996 \\
& \text { FILE: NITRRECV.PWS }
\end{aligned}
$$

AEPORT NAME: Detall Cost by WBS 9697 by seq

\subsection{C/S/A WORK - ADMIN.ABEA}

MISC. FLOOR COVERINGS

TWC CODE:

FQI FORMWORK

TWC CODE:

FQI REBAR

TWC COOE:

F\&ICIP. CONCRETE

Homo:

INCLUDES TRUCK APRON,

\begin{tabular}{|c|c|c|c|c|c|c|}
\hline Unts cost & SASX07 & 0.250 & 0.265 & 28.70 & 1.82 & 9 \\
\hline 5,000 SFCA & & 1.06 & 1,325 & 38,028 & 9,075 & 47,103 \\
\hline Unit Cost & SASXOB & 15.009 & 15.910 & 34.20 & 0.36 & 544 \\
\hline $25 T N$ & & 1.06 & 398 & 13,603 & 9 & 13,612 \\
\hline Unlt Cost & SRS $\times 06$ & 1.500 & 1.590 & 28.30 & 96.80 & 142 \\
\hline $400 \mathrm{CY}$ & & 1.06 & 636 & 18,000 & 38,720 & 56,720 \\
\hline
\end{tabular}

SIDEWALKS, STOOPS, ETC.

\begin{tabular}{llllll} 
Unit cost & 0.000 & 0.000 & N/A & 24.20 & 24 \\
\cline { 2 - 5 } & 1.00 & & 16,940 & 16,940
\end{tabular}

C/S/A WOAK - ADMIN AREA SUBTOTAL

2,598

$\$ 77,320$

$\$ 74,061$

$=2== \pm==2$

$=x== \pm== \pm= \pm=2$

$\$ 494,581$

1.2 .2 .1 .12

ELECTRICALWORK - ADMIN.AREA

MISC. ELECTRICAL WOAK

Momo:

INCLUDES MCC'S AND OTHER

REQUIRED WIRING, CONDUIT,

ONDCABLE FOA CONTRLL ROOM,

\begin{tabular}{|c|c|c|c|c|c|c|}
\hline Unlt cost & SASX20 & 0.250 & 0.265 & 35.60 & 2.42 & 12 \\
\hline 5,720 SF & & 1.06 & 1,516 & 53,962 & 13,842 & 67,805 \\
\hline
\end{tabular}

DCS WISOFTWARE

TWC CODE:

TWC CODE

1 LS

\begin{tabular}{lll} 
SRSX02 $160.000 \quad 169.600$ & 35.90 \\
\hline
\end{tabular}

17500

23589

23,589

ELECTRICAL WORK - ADMIN. AREA SUBTOTAL

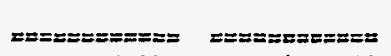

1.685

$\$ 60,051$

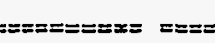

$5==2===2$
$\$ 13,842$

$=\geq== \pm=2=$
$\$ 17,500$

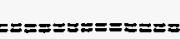

. 
$-$

- WESTINGHOUSE SAVANNAH RIVER COMPANY PROJECTNO: UNEITEM:

LOG NUMBER: 96-05-06, R/1

PROJECT NAME: ELECTOCHEMICAL DENITRATION \& CAUSTIC REC., PHASE I

LOCATION 1: S-AREA

PROS. MANAGER D. HOBBS

ESTIMATE TYPE: PRE-CONCEPTUAL

SITE WBS: SITE WBS

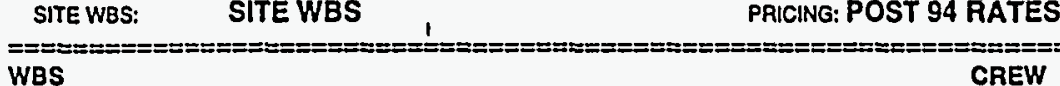

SOURCEITWC DESCRIPTION QUANTITY UOM SUB

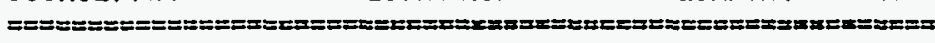

1.221 .1 .3 .1

EQUIPMENT-ADMIN AREA

$\begin{array}{ll}\text { HVAC SYSTEM } \\ \text { MUMO: } \\ \text { TWC CODE: } & \begin{array}{l}\text { INCLUDES DUCTWORK AND HVAC } \\ \text { UNIT AS REQUIRED FOR } \\ \text { COOUNGHEATNO LOADS. }\end{array}\end{array}$

Unit Cost SASX17 0.500

$5,720 \mathrm{~S}$

0.530

34.70

14.52

33

\section{EOUIPMENT - ADMIN.ABEA SUBTOTAL}

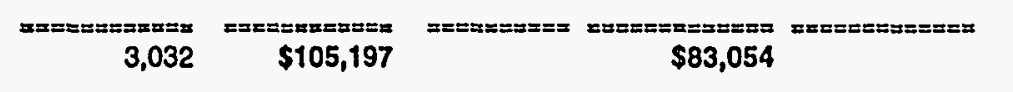

PAGE : 3

ESTIMATED QY: WNWNLKJDM

LOCATION 2: $730-18 / 1080$

DETAIL LINE ITEM REPORT

TIME: 12:56:08

DATE 23-AUg-1996

FILE: NITRRECV.PWS

REPORT NAME: Detall Cost by WBS 9697 by seq

ENGR'D

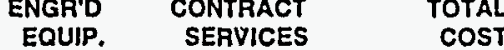

\section{BIPING-ADMIN.ABEA}

FIRE PROTECTION SYSTEM Momo:

INCLUDES DELUGE SYSTEM,

STANDPIPES, AND FIRE

DETECTON.

PLUMBING

TWC CODE:

1.2 .21 .14

TWC CODE:

FURNITURE

Momo:
PIPING-ADMIN AREA SUBTOTAL

\section{MISG. ITEMS - ADMIN.AREA}

ANALYTICAL / OFFICE EQUIPMENT I

1 LS

Unll coot

$5,720 \mathrm{SF}$

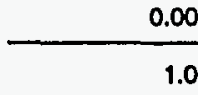

$\begin{array}{lllll}\text { Unlt Cost } & \text { SRSX25 } & 0.200 & 0.212 & 34.80\end{array}$

$1.06 \quad 1,213 \quad 42,200$

6.05

3

5,720 SF

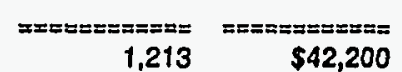

$\$ 34,606$

$=====$

76,806

INCLUDES FUME HOODS

GLOVEBOXES, PORTAL \&
CONSTANT AIR MONITORS.

MISC.ITEMS-ADMIN. ABEA SUBTOTAL
1,590

\begin{tabular}{rrrr} 
SASX13 & 1500.00 & 1590.00 & 32.10 \\
\hline 1.06 & 1.590 & 51,039
\end{tabular}

51,039

$81,500.00$

375000

607539

181,500

375,000

607,539 
$\therefore$.

- W'stingHOUSE SAVANNAH RIVER COMPANY

PROAECT NO: :

UNE ITEM:

LOG NUMBER: 96-05-06, R/

PROJECT NAME: ELECTOCHEMICAL DENITRATION \& CAUSTIC RेEC., PHASE I

LOCATON 1: S-AREA

PROJ. MANAGER D. HOBBS

ESTIMATE TYPE: PRE-CONCEPTUAL

SITE WBS: SITE WBS

SITE WBS ,

PRICING: POST 94 RATES

DETAIL LINE ITEM REPORT

SITE PROJECT ESTIMATING

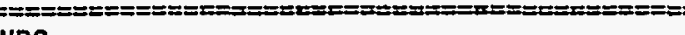

WESCRIPTION OUANTTY UOM CREW

HOURS

LABOR

EQUIP.

CLSIA WORK - PROCESSAREA

1.221 .21

EXTERIOR DOOR $310 \times 710$

WHARDWARE

TWC COOE:

INTERIOR DOOR 3/0 X 7/10

W/HARDWARE

TWC CODE:

FREIGHT ROLL-UP DOOR

TWC CODE:

F\&I FORMWORK

TWC CODE:

F\&I REBAR

TWC CODE:

F\&I C.I.P. CONCRETE

TWC CODE

MISC. EMBEDS (ALLOWANCE)

Homo:

INCLUDES HATCH COVER

HARDWARE

CIVIL / STRUCTURAL / ARCH. (TOTAL PROCESS AREA)

Momo:

ACLUDES ROOFNG, SIDING

AND MISC. NON-CONCRETE

ARIIIONS.

\begin{tabular}{|c|c|c|c|c|c|c|}
\hline Unit cost & SRSX13 & 10,000 & 10.600 & 32.10 & 363.00 & 703 \\
\hline 3 EA & & 1.06 & 32 & 1,021 & 1,089 & 2,110 \\
\hline Unit Cost & SRSX13 & 8.000 & 8.480 & 32.10 & 363.00 & 635 \\
\hline 9 EA & & 1.06 & 76 & 2,450 & 3,267 & 5,717 \\
\hline
\end{tabular}

$\begin{array}{llllll}\text { SASX13 } & 32.000 & 33.920 & 32.10 & 3,630.00 & 4719\end{array}$

$1 \mathrm{EA} \quad \begin{array}{lllll}1.06 & 34 & 1,089 & 3,630 & 4,719\end{array}$

\begin{tabular}{llllll} 
Unll Cost & SRSX07 & 0.250 & 0.265 & 28.70 & 1.82 \\
\hline
\end{tabular}

$\begin{array}{lllll}30,000 \text { SFCA } & 1.06 & 7,950 & 228,165 & 54,450\end{array}$

\begin{tabular}{|c|c|c|c|c|c|c|}
\hline Untl Cost & SRSX08 & 15.000 & 15.910 & 34.20 & 0.36 & 544 \\
\hline $135 \mathrm{TN}$ & & 1.06 & 2,148 & 73,456 & 49 & 73,505 \\
\hline
\end{tabular}

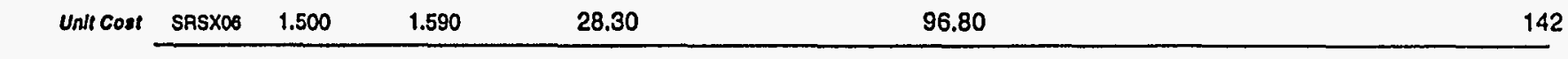

$\begin{array}{lllll}1,500 \mathrm{CY} & 1.06 & 2,385 & 67,496 & 145,200\end{array}$

\begin{tabular}{lrrrrrr} 
Unit Cost & SASX09 & 0.070 & 0.074 & 33.50 & 2.42 & 5 \\
\cline { 2 - 7 } 40,000 LB & & 1.06 & 2,968 & 99,428 & 96,800 & 196,228
\end{tabular}

Unit cost

$0.000 \quad 0.000 \quad$ N/A

$10,780 \mathrm{SF}$
50

539,000

539,000 
$\therefore \cdot$

- WESTINGHOUSE SAVANNAH RIVER COMPANY

PROJECTNO.:

UNE ITEM:

LOO NUMBER: 96-05-05, R/1

PAOJECT NAME: ELECTOCHEMICAL DENITRATION \& CAUSTIC REC., PHASE

LOCATON 1: S-AREA

PROJ. MANAGER D. HOBBS

ESTIMATE TYPE: PRE-CONCEPTUAL

SITE WBS: SITE WBS

ENGINEERING \& CONSTRUCTION SERVICES DIVISION

SITE PROJECT ESTIMATING

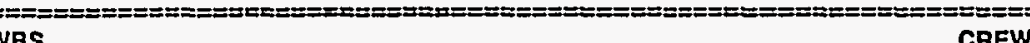

HOURS
BASE ADJST

LABOR

CONST.

PAGE" 5

ESTIMATED BY: WNWNWLKIDM

LOCATION2: $730-18 / 1080$

DESIGN CLASSIFICATION: PS/C

TIME: 12:56:08

OATE 23-AUg-1996

FILE: NITRRECV.PWS

REPORT NAME: Detall Cost by WBS 9697 by seq

ENGR'D CONTRACT

TOTAL

\subsection{C/S/A WOAK-PROCESSAREA}

BRIDGE CRANE SUPPORT SYSTEM

\section{BRIDGE CRANE
FABRICATED}

Memo:

$\cos (\cos 20$

TWC CODE: MOMO:

150 TN

$\begin{array}{lll}0.000 & 0.000 \quad N / A\end{array}$

TOWER, AND MISC. SUPPORTS.

BRIDGE CRANE SUPPORT SYSTEM -

INSTALLATION

TWC CODE:

MISC. FLOOR \& WALL COATINGS

SEALANTS, ETC.

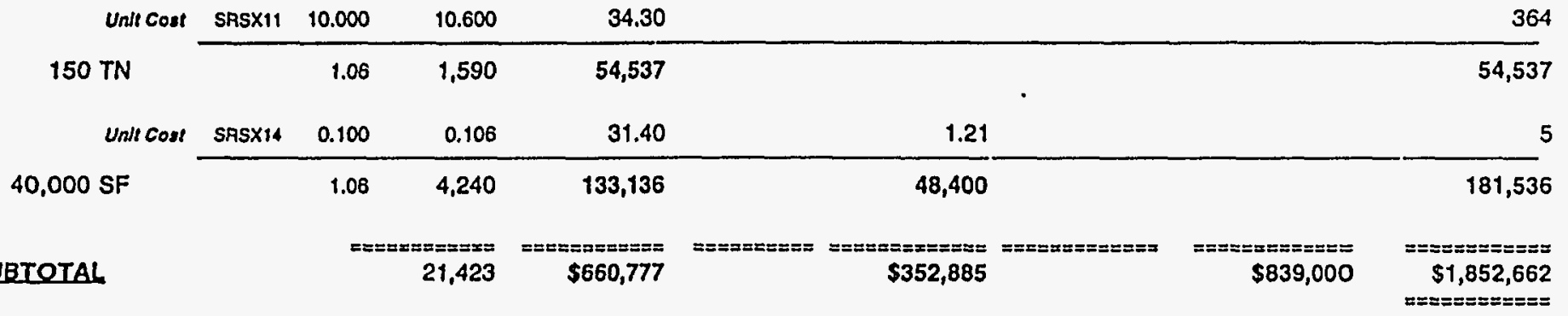

$1,2,2.12 .2$

ELECTRICAL WORK - PROCESS AREA

ELECTRIC BUS, BRIDGE CRANE

TWC CODE:

1 EA

\begin{tabular}{|c|c|c|c|c|c|}
\hline SASXO2 & 160.000 & 169.600 & 35.90 & 12500 & 18589 \\
\hline & 1.08 & 170 & 6,089 & 12,500 & 18,589 \\
\hline
\end{tabular}

PROCESS INSTRUMENTS

TWC CODE:

INSTRUMENT LOOPS

TWC CODE:

CLOSED CIRCUIT TV SYSTEM FOR CRANE

1 LS

\begin{tabular}{|c|c|c|c|c|c|}
\hline & 100.000 & 106.000 & 35.90 & 12500 & 16305 \\
\hline & 1.06 & 106 & 3,805 & 12,500 & 16,305 \\
\hline
\end{tabular}

$\begin{array}{lllll}20 \mathrm{EA} & 1.06 & 763 & 27,399 & 45,000\end{array}$

TWC CODE:

\begin{tabular}{|c|c|c|c|c|}
\hline SRSX02 400.000 & 424.000 & 35.90 & 41250 & 56472 \\
\hline 1.06 & 424 & 15,222 & 41,250 & 56,472 \\
\hline
\end{tabular}


WESTINGHOUSE SAVANNAH RIVER COMPANY

PAOUECTNO::

UNE ITEM

LOG NUMBER: 96-05-06, R/1

PROJECTNAME: ELECTOCHEMICAL DENITRATION \& CAUSTIC REC., PHASE

LOCATION 1: S-AREA

PROS. MANAGER D. HOBBS

ESTIMATE TYPE: PRE-CONCEPTUAL

SITE WBS: SITE WBS

PAICING: POST 94 RATES

DETAIL LINE ITEM REPORT

\section{SITE PROJECT ESTIMATING}

PAGE * 6

ESTMMATED BY: WNWNLKIDM

LOCATION 2: $730-1 B / 1080$

DESIGN CLASSIFICATION: PSIC

TIME: 12:56:08

DATE 23-Aug-1996

FILE: NITRRECV.PWS

REPORT NAME: Detall COSt by WBS 9697 by seq

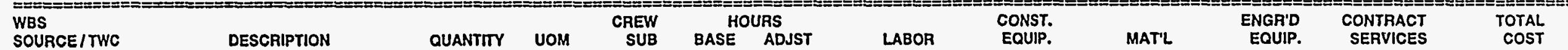

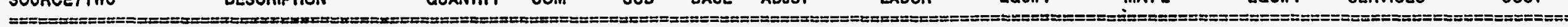

$1.2,2.2 .2$

\section{ELECTRICAL WOAK - PROCESS AREA}

ELECTRICAL WORK FOR TOTAL PROCESS AREA

TWC CODE:

TWC CODE

ADDITIONAL ELECTRICAL WORK

FOR PROCESS AREA

Momo:

NCLUDES PRICING AND LABOR

FRPLOSION PROOF

STANLESS STEEL CONDUTT AND

FIXTURES.

\section{ELECTRICAL WOBK - PROCESS AREA SUBTOTAL}

$10,780 \mathrm{SF}$

Unte COSt' SRS $\times 20$

$0.250 \quad 0.265$

35.60

2.42

12

Unit Cost SRSX20

$\begin{array}{lll}1.06 & 2,857 & 101,699\end{array}$

26,088

127,786

5,720 SF

$0.300 \quad 0.318$

35.60

9.68

$\begin{array}{lll}1.06 & 1,819 & 64,755\end{array}$

55,370

120,125

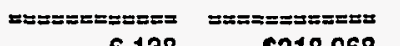

$\$ 218,968$

$\$ 111,250$

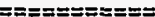

1.2 .2 .12 .3 .1

10 TON BRIDGE CRANE HOIST,

CABLE, TROLLEY, ETC.

Momo:

ASSUME 10 TON CRANE

CAPACTT, FLOOR OPERATED

(INCLUDES FREIOHT.

F\&I FEED \& SAMPLE TANKS

Memo:

PAICING ARE FOR TWO TANKS

14' DIA X $\times 18^{\prime}$ HIGH X 12:

THK. SO4 SST (EOP. 100-TK

1:2)

F\&I CHEMICAL FLUSH TANK

$\begin{array}{ll}\text { TWC CODE: } & \text { PRICINO FOR TANK } V \text { DIA X } X \\ & 12^{\circ} \text { HIGH X } 3 \mathrm{~S}^{\circ} \text { THK } 304 \text { SST }\end{array}$

$\begin{array}{ll}\text { TWC CODE: } & \text { PRICING FOR TANK } Y \text { DIA } X \\ & 1^{\circ} \text { HIGH X S SE' THK 3O4 SST }\end{array}$

(EO. 1 100-TK.).

\begin{tabular}{lrrrrrr} 
& SASX01 222.223 & 235.556 & 35.20 & 125000 & 133292 \\
\cline { 2 - 8 } & 1.08 & 236 & 8,292 & 125,000 & 133,292
\end{tabular}

\begin{tabular}{lrrrrr} 
Unit Cost SRSX01 & 0.015 & 0.016 & 35.20 & 6.05 & 7 \\
\cline { 2 - 6 } 54,000 LB & 1.06 & 859 & 30,223 & 326,700 & 356,923
\end{tabular}

\begin{tabular}{llllll} 
& SRSX01 & 0.030 & 0.032 & 35.20 & 6.05 \\
\cline { 2 - 6 } & 1.06 & 245 & 8,619 & 46,585
\end{tabular}




\section{ENGINEERING \& CONSTRUCTION SERVICES DIVISION}

WESTINGHOUSE SAVANNAH RIVER COMPANY

PROJECTNO:: ·

UNE ITEM:

LOS NUMBER: 96-05-06, R/1

PROJECT NAME: ELECTOCHEMICAL DENITRATION \& CAUSTIC ṘEC., PHASE I

LOCATION 1: S-AREA

PROI. MANAGER D. HOBBS

ESIMMATE TYPE: PRE-CONCEPTUAL

SITE WBS: SITE WBS

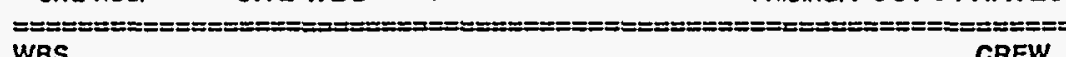

SITE PROJECT ESTIMATING
DESCRIPTION

SUB

\section{DETAIL LINE ITEM REPORT}

\subsection{2 .123 .1 \\ EQUIPMENT-PRQCESS AREA}

F\&I KNOCK-OUT POT

(EQ. 100-MS-1)

F\&I FEED TANK PUMP

REF. 1500 GPM, 300 TDH (EQ

100-P-1 \& P-2), LNCLUDES

MOTOR.

F\&I SPARE FEED TANK PUMP

Moñ:

PEF. 1500 OPM, 300 TDH (EO.

100-P-2), INCLUDES MOTOR.

F\&I SAMPLE TANK PUMP

Momo:

MAQNETTC DRIVE, CENTRIFUGAL

(EO. 100-P.S), REF. 140

F\&I SPARE SAMPLE TANK PUMP

Memo:

MAGNETIC DRIVE, CENTRIFUGAL

(EO. 100-PA), AEF. 140

GPM, 20 TOH, NCLUDES MOTOR.

F\&I CHEMICAL FLUSH PUMP

Homo:

(EO. 100.P.5), REF. 300

GPU, 250 TDH, INCLUDES

MOTOR.

F\&I SUMP PUMP

(EQ. 100-SP.1)

F\&I DEMISTER

Homo:

(EO. 1 100-MS-2)

\begin{tabular}{|c|c|c|c|c|c|c|}
\hline & SRS $\times 01$ & 120.000 & 127.200 & 35.20 & $6,050.00$ & 10527 \\
\hline $1 \mathrm{EA}$ & & 1.06 & 127 & 4,477 & 6,050 & 10,527 \\
\hline Unti cost & SRSX01 & 89.888 & 95.281 & 35.20 & 28750 & 32104 \\
\hline 2 EA & & 1.06 & 191 & 6,708 & 57,500 & 64,208 \\
\hline
\end{tabular}

1 EA

\begin{tabular}{rrrrrr} 
SRSX01 & 89.888 & 95.281 & 35.20 & 28750 & 32104 \\
\hline 1.06 & 95 & 3,354 & 28,750 & 32,104
\end{tabular}

I EA

\begin{tabular}{rrrrrr} 
SRSX01 & 40.000 & 42.400 & 35.20 & 6250 & 7742 \\
\hline 1.06 & 42 & 1,492 & 6,250 & 7.742
\end{tabular}

1 EA

\begin{tabular}{lrrrrr} 
SRSX01 & 40.000 & 42.400 & 35.20 & 6250 & 7742 \\
\hline 1.06 & 42 & 1,492 & 6,250 & 7,742
\end{tabular}

1 EA

\begin{tabular}{|c|c|c|c|c|c|}
\hline SA5X01 & 47.904 & 50.778 & 35.20 & 10000 & 11787 \\
\hline & 1.06 & 51 & 1,787 & 10,000 & 11,787 \\
\hline
\end{tabular}

$1 \mathrm{EA}$

\begin{tabular}{rrrrrr} 
SRSX01 & 24.000 & 25.440 & 35.20 & 3750 & 4645 \\
& 1.06 & 25 & 895 & 3,750 & 4,645 \\
SRSX01 & 40.000 & 42.400 & 35.20 & 6250 & 7742 \\
\hline & 1.06 & 42 & 1,492 & 6,250 & 7,742
\end{tabular}

PAGE: 7

ESTIMATED BY: WNWNWLKJDM

DESIGN CLASSIFICATION: PS/C

TIME: 12:56:08

DATE 23-Aug-1996

REPORT NAME: Detall Cost by WBS 9697 by seq

HOURS CONST. ENGR'D CONTRACT TOTAL


$:$

- W'ESTINGHOUSE SAVANNAH RIVER COMPANY

PAOUECT NO.:

UNE ITEM:

LOQ NUMBER: 96-05-06, R/1

PROJECT NAME: ELECTOCHEMICAL DENITRATION \& CAUSTIC REC., PHASE

LOCATION 1: S-AREA

PROJ. MUNAGER D. HOBBS

ESTMUTE TYPE: PRE-CONCEPTUAL

SITE WBS: SITE WBS

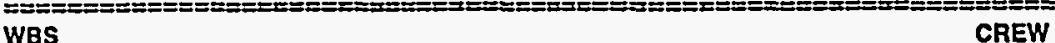

SOURCE/TWC DESCRIPTION QUANTITY UOM CRUB

EQUIPMENT - PROCESS AREA

$1.22,1,2,3.1$

F\&I SEAL POT

TWC CODE:

TWC CODE:

F\&I ELECTROCHEMICAL REACTORS

Momo:

ELECTROLYSERS FU21.SP

MANFACTURED GYICL.SP

VENDOR BUDOET OUOTE:

\$100,000 E \& INCLUDES $10 \%$

FOR FREGATT OUTY (EQ.

100-ECI THAU 10).

VENDOR TECHNICAL

REPRESENTATIVE

TWC CODE:

VENTILATION SYSTEM

TWC CODE:

FIRE EXTINGUISHER / SMOKE

DETECTORS ALLOWANCE

rwC COoE:

PROCESS ROOM HEPA FILTER

PROCES

(EO. 100-FL.T.1 2 2)

BLOWER FOR HEPA FILTER

Momo:

(EO. 100-BLR-1)

ROOM EXHAUST BLOWER

Momo:

(EQ. 100-BLP-3)

SPARE BLOWER FOR HEPA FILTER

Momo:

(EQ.1 100-BLA-2)
SUB HOURS

HOURS

\begin{tabular}{rrrrrrrrr} 
& SASX01 & 40.000 & 42.400 & 35.20 & & 6250 & 7742 \\
\cline { 2 - 8 } 1 EA & 1.06 & 42 & 1,492 & & 6,250 & 7,742 \\
Unit Cost & SRSX01 & 300.000 & 318.000 & 35.20 & 605.00 & 137500 & 149299 \\
\cline { 2 - 8 } 10 EA & 1.06 & 3,180 & 111,936 & 6,050 & $1,375,000$ & $1,492,986$
\end{tabular}

ESTMATEDBY: WNW/WLKJDM

LOCATION 2: 730-1B/1080

DESIGN CLASSIFICATION: PS/C

TIME: 12:56:08

DATE 23-Aug-1996

FILE: NITRRECV.PWS

REPORT NAME: Detall Cost by WBS 9697 by seq $=============================$

CONTRACT
EQUIP.
SERVICES TOTAL
COST

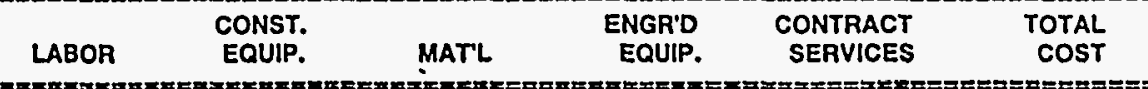

$10 \mathrm{EA}$
SITE PROJECT ESTIMATING

DETAIL LINE ITEM REPORT

.

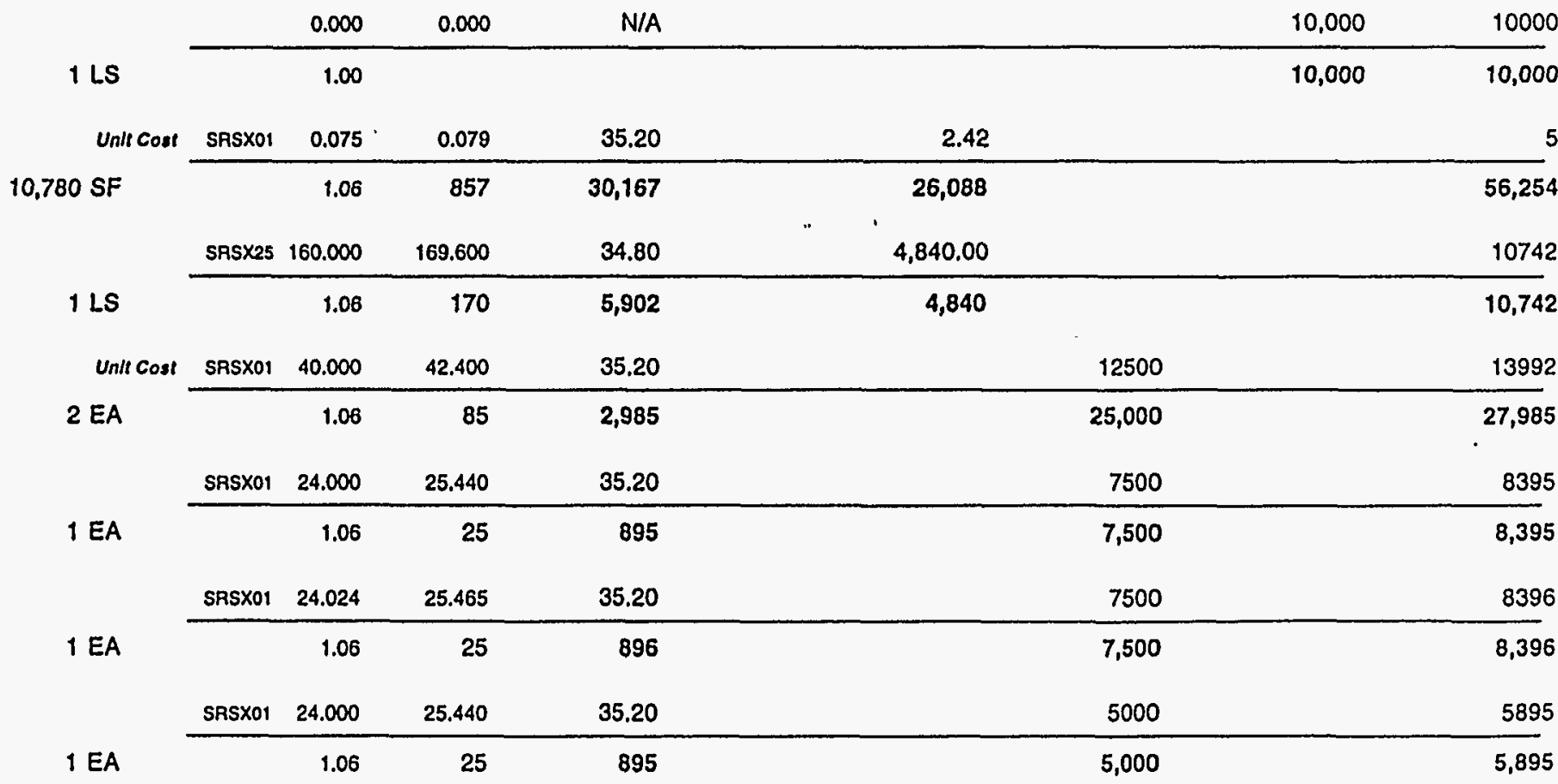

(2)


ENGINEERING \& CONSTRUCTION SERVICES DIVISION

SITE PROJECT ESTIMATING

DETAIL LINE ITEM REPORT
: $\cdot$.

- WÉSTINGHOUUSE SAVANNAH RIVER COMPANY

PROJECTNO::

UNE ITEM:

LOO NUMBER: 96-05-06, R/1

PROJECT NAME: ELECTOCHEMICAL DENITRATION \& CAUSTIC REC., PHASEI

PROS. MUNAGER D. HOBBS

ESTMUTE TYPE: PRE-CONCEPTUAL

SITE WBS

PRICING: POST 94 RATES
LOCATION 1: S-AREA

SITEWBS: SITE WBS

PAGE 9

ESTIMATED BY: WNWIWLKJDM

LOCAMON 2: 730-1B/1080

DESIGN CLASSIFICATION: PS/C

TIME: 12:56:08

DATE 23-Aug-1996

FILE: NITRRECV.PWS

REPORT NAME: Detall Cost by WBS 9697 by seq

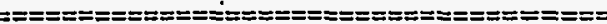

WOS SOURCE/TWC DESCRIPTION QUANTITY UOM CREW

1.2.2.12.3.1 EQUIPMENT-PROCESSAREA

HEATER FOR HEPA FILTERS

Momo:

(EO. 1 100-EHTA-1)

1 EA

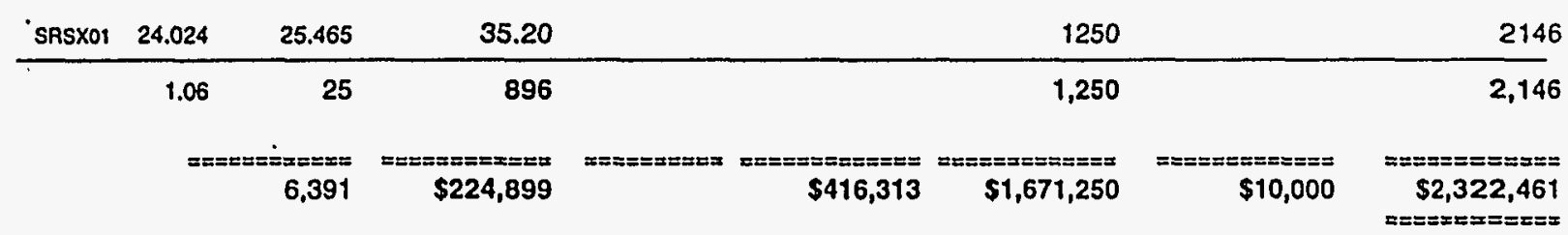

EQUIPMENT-PROCESS AREA SUBTOTAL

PIPING - PROCESS AREA

$1.2,2.1,2,3,2$

MISC. PROCESS PIPING WITHIN

BLDG.

INCLUDES FITINAS, FLANGES,

BOLTUP, AND ALL WELDINO TO

FAB \& INSTALL PIPING. ALSO

INCLUDES ALLOWANCE FOR

SEISMIC SUPPORTS. (BASED ON

$0,10^{\circ}, 212^{\circ}$ OIA S

MISC. PROCESS VALVES

TWC CODE:

MISC. CONTROL VALVES

TWC CODE:

PLUMBING

TWC CODE:

\begin{tabular}{lrrrrrr} 
Unlt Cost & SRS $\times 25$ & 14.011 & 18.214 & 34.80 & 242.00 & 876 \\
\cline { 2 - 7 } $400 \mathrm{LF}$ & 1.30 & 7,285 & 253,534 & 96,800 & 350,334
\end{tabular}

\begin{tabular}{|c|c|c|c|c|c|c|}
\hline Unit cost & SRSX25 & 6.002 & 7.802 & 34.80 & $7,260.00$ & 7532 \\
\hline EA & & 1.30 & 328 & 11,403 & 304,920 & 316,323 \\
\hline
\end{tabular}

\begin{tabular}{|c|c|c|c|c|c|c|}
\hline Unit Cost & SASX25 & 11.994 & 15.592 & 34.80 & $24,200.00$ & 24743 \\
\hline 2 EA & & 1.30 & 31 & 1,085 & 48,400 & 49,485 \\
\hline
\end{tabular}

$\begin{array}{lllll}\text { Unll Cost } & \text { SASX25 } & 0.050 & 0.053 & 34.80\end{array}$

1.45

3

$10,780 \mathrm{SF}$

$\begin{array}{lll}1.06 & 571 & 19,883\end{array}$

15,653

35,535

PIPING - PROCESS AREA SUBTOTAL 
$\cdot \cdot$

WESTINĠHOUSE SAVANNAH RIVER COMPANY

PAOSECTNO:

UNE ITEM:

LOG NUMBER: 96-05-06, R/1

PROJECT NAME: ELECTOCHEMICAL DENITRATION \& CAUSTIC REC., PHASE I

LOCATION 1: S.AREA

PROJ. MANAGER D. HOBBS

DETAIL LINE ITEM REPORT

ESTIMATE TYPE: PRE-CONCEPTUAL

SITEWBS: SITE WBS

SITE PROJECT ESTIMATING

ESTIMATEO BY: WNWIWLKJDM

LOCATION 2: 730-1B/1080

DESIGN CLASSIFICATION: PSIC

TIME: $12: 56: 08$

DATE 23-AUg-1996

FILE: NITRRECV.PWS

REPORT NAME: Detall Cost by WBS 9697 by seq

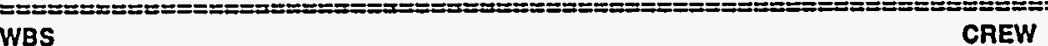

DESCRIPTION

QUANTITY UOM

SUB

HOURS

ASE ADJST

LABOR CONST.

MAT'L

ENGR'D CONTRACT

EQUIP. SERVICES
SET

TOTAL

$1.22,2.1$

SIVIL WORK - SITEWORKUTILITIES

MISC. GPR \& SUE INVESTIGATIONS

Mamo:

ASSUME 1/2 AREA WIL BE

CHECKED.

AIR-KNIFE EXCAVATION •

UNDERGROUND TIE.IN LOCATIONS

TWC CODE:

MISC. BARRICADES, TEMPORARY

SIGNS AND TRAFFIC CONTROLS

TWC CODE:

EXCAVATION DEWATERING ALLOWANCE

TWC CODE:

MISC. PERMANENT BUILDING SIGNS, FLOOR STRIPING, AREA

TWC CODE:

IDENTIFICATION

MISC. EXCAVATION (HAND \&

MACHINE) - CLEAN AREA

MISC. EXCAVATION (HAND \& MACHINE) - HAZARD AREA

Momo:

- TIE-AN POINTS TO TRANSFER

LNE.

SHORING

TWC CODE:

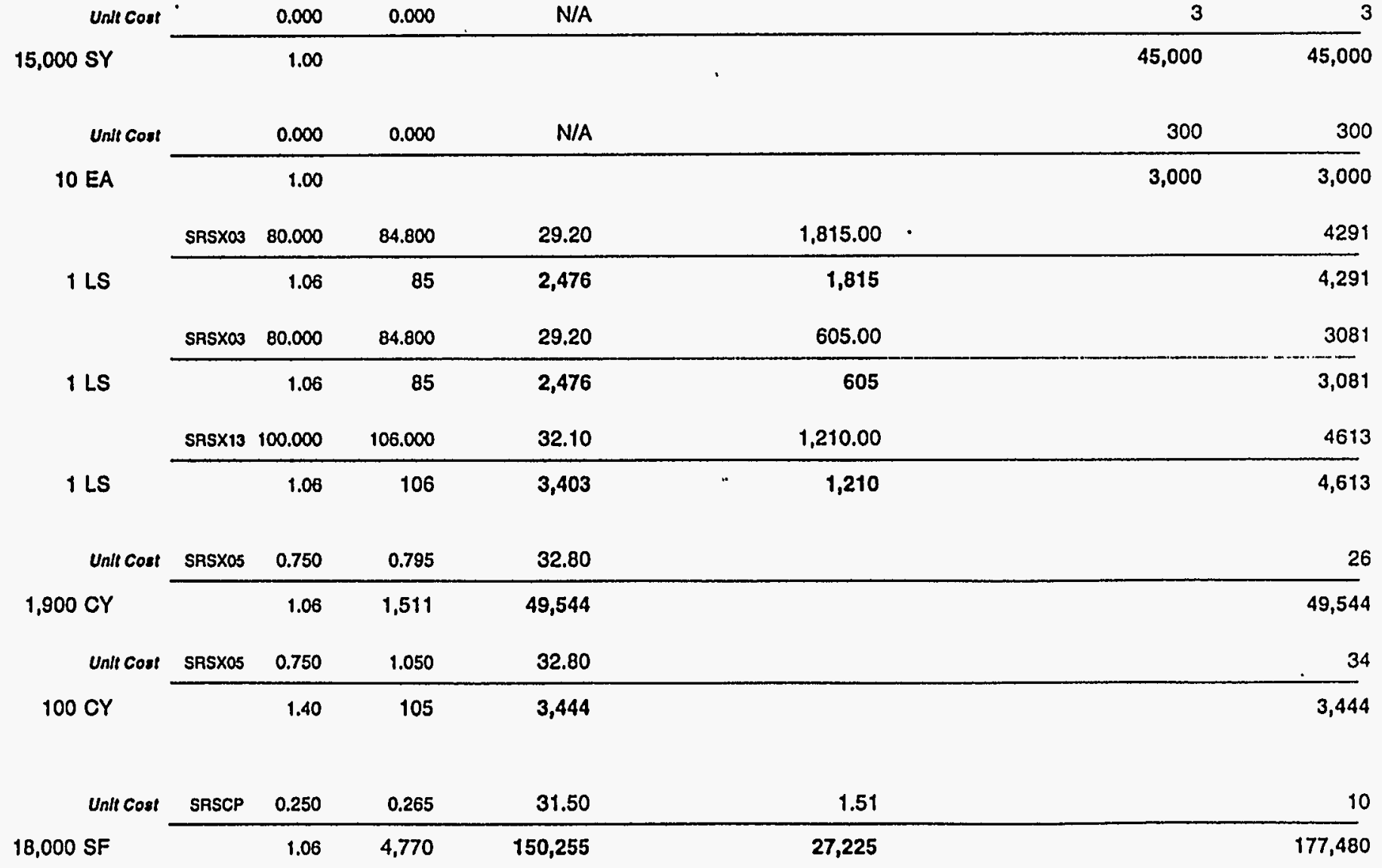




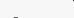

- WËSTINĠHOUSE SAVANNAH RIVER COMPANY

PAONECTNO:

UNE ITEM:

LOG NUMBER: 96-05-06, R/1

PROJECT NAME: ELECTOCHEMICAL DENITRATION \& CAUSTIC REC., PHASE I

LOCATION 1: S-AREA

PROJ. MANAGER D. HOBBS

ESTIMATE TYPE: PRE-CONCEPTUAL

SITE WBS: SITE WBS ,

PRICING: POST 94 RATES

SITE PROJECT ESTIMATING

WBS
WBS

\section{DETAIL LINE ITEM REPORT}

QUANTIYY UOM

CREW HOURS

HOURS
ADJST

LABOR

EQUIP.

CIVIL WOBK - SITEWORKUTILITIES

$1,2,2,1$

BACKFILL \& COMPACTION

Momo:

INCLUDES ALL EXCAVATIONS AND

STRUCTURAL FILL

LOAD \& HAUL STRUCTURAL FILL

TWC CODE:

S.O.G STONE BASE

TWC CODE:

STORM SEWER CATCH BASINS

TWC CODE:

24" DIA. CMP DRAINAGE

TWC CODE:

MISC. SITE GRADING

TWC CODE:

MISC. SITE RESTORATION

NWC CODE:

MISC. CONSTRUCTION

TWC CODE:

SANITARY SEWER PIPE

\begin{tabular}{rrrrrr} 
Unlt Cost & SRSX03 & 0.150 & 0.159 & 29.20 & 5 \\
\cline { 2 - 5 } $12,000 \mathrm{CY}$ & & 1.06 & 1,908 & 55,714 & 55,714 \\
& & & & & \\
Unit Cost & SRSX03 & 0.220 & 0.233 & 29.20 & 7 \\
\cline { 2 - 5 } $14,000 \mathrm{CY}$ & 1.06 & 3,265 & 95,332 & 95,332
\end{tabular}

\begin{tabular}{|c|c|c|c|c|c|c|}
\hline Unit cost & SRSXO3 & 0.150 & 0.159 & 29.20 & 12.10 & 17 \\
\hline $1,000 \mathrm{TN}$ & & 1.06 & 159 & 4,643 & 12,100 & 16,743 \\
\hline
\end{tabular}

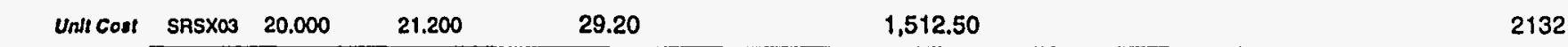

$\begin{array}{llllll}3 \mathrm{EA} & 1.06 & 64 & 1,857 & 4,538 & 6,395\end{array}$

\begin{tabular}{lrrrrrr} 
Unds Cost & SASX03 & 0.200 & 0.212 & 29.20 & 30.25 & 36 \\
\cline { 2 - 7 } $170 \mathrm{LF}$ & 1.06 & 36 & 1,052 & 5,143 & 6,195
\end{tabular}

$\begin{array}{llll}\text { Unit Cost SRSX03 } \quad 0.020 \quad 0.021 \quad 29.20 & 1\end{array}$

$13,500 \mathrm{sY} \quad 1.06 \quad 286 \quad 8,357 \quad 8,357$

\begin{tabular}{llllll} 
Unll Cost & SASX03 & 0.050 & 0.053 & 29.20 & 2.42 \\
\hline
\end{tabular}

$\begin{array}{lllll}11,700 \mathrm{SY} & 1.06 & 620 & 18,107 & 28,314\end{array}$

\begin{tabular}{llllll} 
& SASX03 300.000 & 318.000 & 29.20 & $12,100.00$ & 21386 \\
\cline { 2 - 6 } & 1.06 & 318 & 9,286 & 12,100 & 21,386
\end{tabular}

\begin{tabular}{|c|c|c|c|c|c|c|}
\hline Unte Cost & SRSX25 & 0.100 & 0.106 & 34.80 & 1.82 & 6 \\
\hline 500 LF & & 1.06 & 53 & 1,844 & 908 & 2,752 \\
\hline
\end{tabular}


$\therefore \cdot$

- WËSTINGHOUSE SAVANNAH RIVER COMPANY

PROSECTNO::

UNE ITEM:

LOG NUMBER: 96-05-05, R/1

PROJECT NAME: ELECTOCHEMICAL DENITAATION \& CAUSTIC RÈC., PHASEI

LOCATION 1: S-AREA

PROJ. MANAGER D. HOBBS

ESTIMATE TYPE: PRE-CONCEPTUAL

SITE WBS:

SITE WBS

i

PRICING: POST 94 RATES

DETAIL LINE ITEM REPORT

SITE PROJECT ESTIMATING

\section{DETAIL LINE ITEM REPORT}

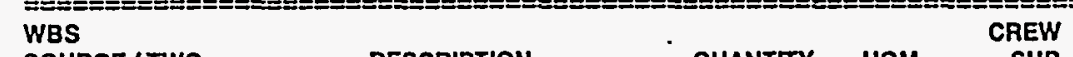

SOURCE/TWC

DESCRIPTION

QUANTITY UOM

HOURS

HOURS

ADJST
LABOR
EQUIP.

CONST.

DIVISION

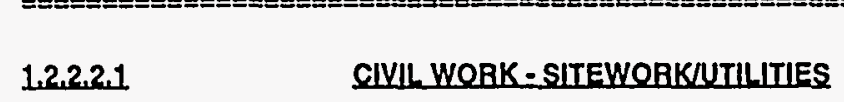

PAVING BASE

TWC CODE:

MISC. SITE PAVING

TWC CODE:

MISC. CISIA TESTING \&

INSPECTIONS

TWC CODE:

\section{CIVIL WOBK - SITEWOAKRTILITIES SUBTOTAL}

Unit Cost
$150 \mathrm{TN}$
Unit Cost

$\begin{array}{llll}\text { SRSX03 } & 0.100 & 0.106 & 29.20\end{array}$

12.10

15

$100 \mathrm{TN}$

$\begin{array}{lll}0.000 & 0.000 \quad N / A\end{array}$

1 LS

\begin{tabular}{ccccc}
0.000 & 0.000 & N/A & 10,000 & 10000 \\
\hline 1.00 & & 10,000 & 10,000
\end{tabular}

LOCATION 2: $730-1 B / 1080$
DESIGN CLASSIFICATION: PS/C

TIME: 12:56:08

DATE 23-Aug-1996

FILE: NITRRECV.PWS

REPORT NAME: Detall Cost by WBS 9697 by seq $================E============3=$ \begin{tabular}{cc} 
ENGR'D & CONTRACT \\
EQUIP. & TOTAL \\
\hline
\end{tabular}

$\begin{array}{llcc}\text { ENGR'D } & \text { CONTRACT } & \text { TOTAL } \\ \text { MAT'L } & \text { EQUIP. } & \text { SERVICES } & \text { COST }\end{array}$

$1.2,2.2,2$

ELECTRICAL WORK - SITEWORKUTILITIES

DUCTBANK

\begin{tabular}{|c|c|c|c|c|c|c|}
\hline Unlt Cost & SRSX2O & 1.600 & 1.696 & 35.60 & 42.35 & 103 \\
\hline $450 \mathrm{LF}$ & & 1.06 & 763 & 27,170 & 19,058 & 46,227 \\
\hline
\end{tabular}

ELECTRICAL MANHOLES

TWC CODE:

OUTSIDE WIRING

IWC CODE:

YARD LIGHTING

WC CODE:

\begin{tabular}{|c|c|c|c|c|c|c|}
\hline Unlt Cost & SRS $\times 20$ & 16.000 & 16.860 & 35.60 & 605.00 & 1209 \\
\hline $2 \mathrm{EA}$ & & 1.06 & 34 & 1,208 & 1,210 & 2,418 \\
\hline
\end{tabular}

$1 L T$

\begin{tabular}{rrrrrr} 
SRSX20 & 85.000 & 90.100 & 35.60 & $39,930.00$ & 43138 \\
\hline 1.06 & 90 & 3,208 & 39,930 & 43,138
\end{tabular}

$1 \mathrm{LT}$

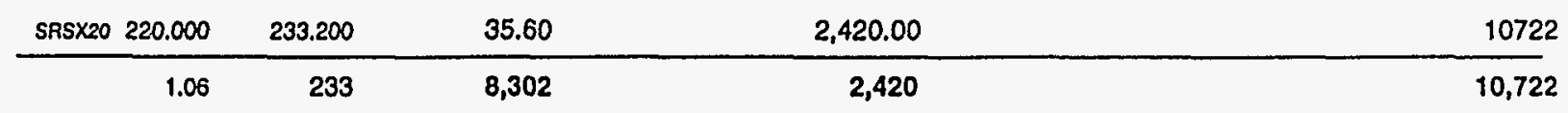

ELECTRICAL WOBK - SITEWORKUTILITIES SUBTOTAL

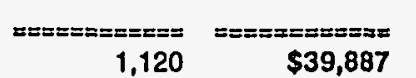

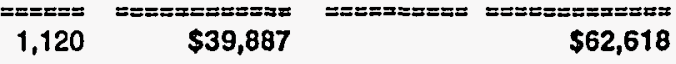

$=======2=$

$\$ 102,504$ 
WESTINGHOUSE SAVANNAH RIVER COMPANY PROJECTNO:

LINE ITEM:

LOG NUMBER: 96-05-06, R/1

PROJECT NAME: ELECTOCHEMICAL DENITRATION \& CAUSTIC REC., PHASE

LOCATION 1: S-AREA

PROJ. MANAGER D. HOBBS

ESTMMTE TYPE: PRE-CONCEPTUAL

SITE WBS: SITE WBS

\section{DETAIL LINE ITEM REPORT}

PRICING: POST 94 RATES
PAGE" 13

ESTIMATED BY: WNW/WLKJDM

LOCATON 2: 730-1B/1080

DESIGN CLASSIFICATION: PS/C

TIME: $12: 56: 08$

DATE 23-Aug-1996

FILE: NITRRECV.PWS

REPORT NAME: Detall Cost by WBS 9697 by seq

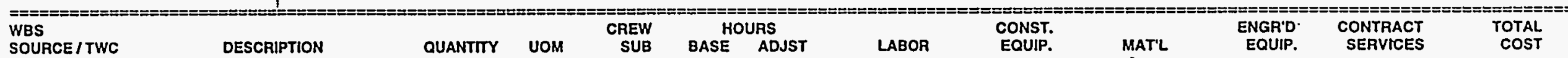

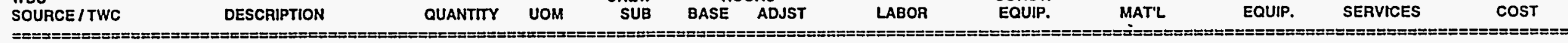

1.2 .2 .2 .3 .1

EQUIPMENT - SITEWORKUTILITIES

EXHAUST STACK FOR HEPA FILTER

SYSTEM - FABRICATED

TWC CODE:

EXHAUST STACK FOR HEPA FILTER SYSTEM - INSTALATION

LIFT STATION

TWC CODE:

\section{EQUIPMENT - SITEWORKUTILITIES SUBTOTAL}

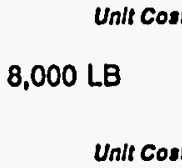

8,000 LB

SAlt Cost SAX11

$\begin{array}{rrrr}1.06 & 106 & 3,636\end{array}$

\begin{tabular}{rrrrr} 
SASX01 120.000 & 127.200 & 35.20 & $18,150.00$ & 22627 \\
\hline 1.06 & 127 & 4,477 & 18,150 & 22,627
\end{tabular}

$1 \mathrm{EA}$

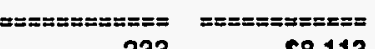

$\$ 8,113$

$\$ 18,150$

$\$ 20,000$

$z== \pm== \pm== \pm=2$

CORE/SKT. WASTE TRANSFER LINE - SITEWORK
SHOP FAB 3. DIA. CORE / $4^{\circ}$ DIA. JACKETED TRANSFER PIPING

NWC CODE:

TIE-IN NEW COREJJKT. TRANSFER

PIPING

MOMO:

EXISTNG INTERAREA TRUNSFE

LINE, BEVELING O TE-IN

POINT, NND WELDINO NEW

COREJKT. PIPELEADING TO

MHRS FOR VACUUM BOX TESTING

OF TE-IN WELDS.

FIELD INSTALL NEW COREJJKT.

TRANSFER PIPING

\begin{tabular}{lrrrrrr} 
Unit Cost & SRSX25 & 5.000 & 5.000 & 34.80 & 42.35 & 216 \\
\cline { 2 - 7 } 320 LF & 1.00 & 1,600 & 55,680 & 13,552 & 69,232 \\
Unit Cost & SRSX25 & 40.000 & 112.000 & 34.80 & & 3898 \\
\cline { 2 - 6 } 2 EA & 2.80 & 224 & 7,795 & 7,795
\end{tabular}

320 LF
418

133,632 


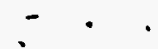

- WÉsting Ḣouse SAVANNAH RIVER COMPANY

PROJECTNO:

LINE ITEM:

LOG NUMBER: 96-05-06, R/1

PROJECT NAME: ELECTOCHEMICAL DENITRATION \& CAUSTIC REC., PHASEI

LOCATION 1:

S-AREA

PROJ. MUNAGER D. HOBBS

ESTIMATE TYPE: PRE-CONCEPTUAL

SITE WBS:

SITE WBS

PRICING: POST 94 RATES

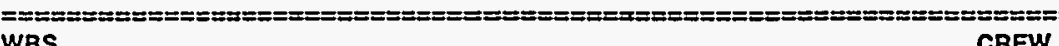

\section{SITE PROJECT ESTIMATING \\ PAGE』 .14}

ESTIMATED BY: WNWNLKJDM

LOCATION 2: 730-1B/1080

DESIGN CLASSIFICATION: PSIC

TIME: $12: 56: 08$

DATE 23-Aug-1996

FILE: NITRRECV.PWS

REPORT NAME: Detall Cost by WBS 9697 by seq

ENGR'D CONTAACT TOTAL

EQUIP. SERVICES COST

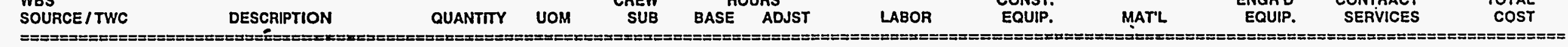

$1,2,2,2,3,2.1$

TESTING OF NEW TRANSFER LINE

TWC CODE:

OUTSIDE MAN \& FIRE WATCH

TWC CODE:

VALVE BOX WISOLATION VALVES

TWC CODE:

$1.2,2.2,3.2 .2$

TWC CODE:

FLUSHING AND TESTING OF SYSTEM

TWC COOE:

2. DIA. DOMESTIC WATER PIPING

INSTALL NEW 6" DIA. PVC

UNDERGROUND FIRE PROTECTION

PIPE

\section{COREJKKT. WASTE IRANSFER LINE - SITEWORK}

\begin{tabular}{lrrrrr} 
Untl cost & SASX25 & 0.400 & 0.424 & 34.80 & 15 \\
\cline { 2 - 6 } 320 LF & 1.06 & 136 & 4,722 & 4,722
\end{tabular}

\begin{tabular}{rrrrr} 
& SRSX25 3800.00 & 3800.00 & 34.80 & 132240 \\
\cline { 2 - 5 } 1 LS & 1.00 & 3,800 & 132,240 & 132,240
\end{tabular}

\begin{tabular}{lrrrr} 
Unlt Cost SRSX25 $240.000 \quad 360.000$ & 34.80 & $2,420.00$ & 14948 \\
\hline
\end{tabular}

25,056

29,896

CORELSKT. WASTE IRANSFERLINE-SITEWORK SUBTOTAL

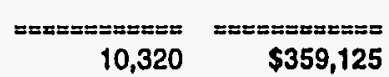

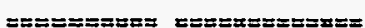
$\$ 18,392$

$\$ 377,517$

DOMESTIC WATER - SITEWORK

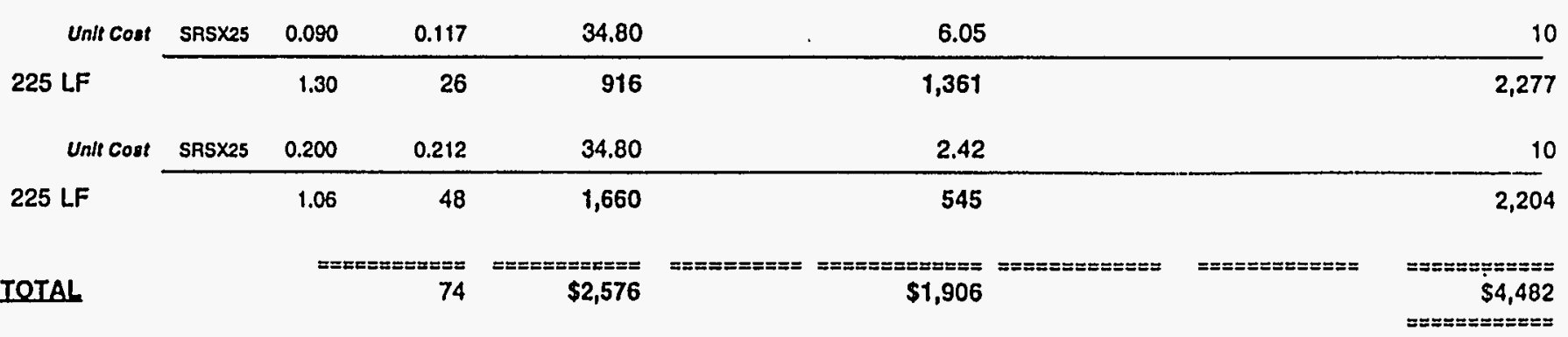

DOMESTIC WATER - SITEWORK SUBTOTAL

EIRE PROTECTION PIPING - SITEWOBK

\begin{tabular}{|c|c|c|c|}
\hline Unll Coot & SASX25 & 0.140 & 0.182 \\
\hline 175 LF & & 1.30 & 32 \\
\hline
\end{tabular}

9.68 
- WĖSTINGHOUSE SAVANNAH RIVER COMPANY

PROSECT NO:

UNEITEM:

LOG NUMBER: 96-05-06, R/1

PROJECT NAME: ELECTOCHEMICAL DENITRATION \& CAUSTIC REC., PHASE

LOCATION 1: S-AREA

PROJ. MANAGER D. HOBBS

ESTIMATE TYPE: PRE-CONCEPTUAL

SITE WBS: SITE WBS

SITE WBS

DETAIL LINE ITEM REPORT

PRICING: POST 94 RATES

\section{SITE PROJECT ESTIMATING}

ESTIMATED BY. WNWNWLKJDM

LOCATON 2: 730-1B/1080

DESIGN CLASSIFICATION: PSIC

TIME: 12:56:08

DATE 23-Aug-1996

FILE: NITRRECV.PWS

REPORT NAME: Detall Cost by WBS 9697 by seq

CREW
WOS

WBS
SOURCE/TWC DESCRIPTION QUANTTY UOM CREW
SUB

HOURS
HO ADST

LABOR

CONST.

EQUIP.

MAT'L

ENGR'D

EQUIP.

CONTBACT

SERVICES

TOTAL
COST

EIRE PROTECTION PIPING - SITEWORK

TIE-IN NEW UNDERGROUND FIRE

PROTECTION PIPING

TESTING OF UNDERGROUND FIRE

PROTECTION PIPING

FIRE HYDRANT

POST INDICATOR VALVE

Momo:

INCLUDES POST AND CONCRETE

GUARDS.

\begin{tabular}{|c|c|c|c|c|c|c|}
\hline Unll Cost & SRSX25 & 6.000 & 9.600 & 34.80 & & 334 \\
\hline $2 \mathrm{EA}$ & & 1.60 & 19 & 668 & & 668 \\
\hline Unll Cost & SRSX25 & 0.250 & 0.265 & 34.80 & 1.21 & 10 \\
\hline 175 LF & & 1.06 & 46 & 1,614 & 212 & 1,826 \\
\hline & SRS $\times 25$ & 2.000 & 2.600 & 34.80 & 1.331 .00 & 1421 \\
\hline $1 \mathrm{EA}$ & & 1.30 & 3 & 90 & 1,331 & 1,421 \\
\hline & SRSX25 & 8.000 & 10.400 & 34.80 & 1.210 .00 & 1572 \\
\hline $1 E A$ & & 1.30 & 10 & 362 & 1,210 & 1,572 \\
\hline
\end{tabular}

EIRE PROTECTIONPIPING - SITEWORK SUBTOTAL

110

$\$ 3,843$

$\$ 4,447$

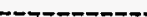

MISC.ITEMS - SITEWORKUUTILITIES

CONTAINMENT HUT

TWC CODE:

BURIAL BOX

\begin{tabular}{|c|c|c|c|c|c|c|}
\hline & SRSX27 & 70.000 & 74.200 & 24.40 & $4,840.00$ & 6650 \\
\hline 1 EA & & 1.06 & 74 & 1,810 & 4,840 & 6,650 \\
\hline Unll cost & SRSX27 & 8.000 & 8.480 & 24.40 & 423.50 & 630 \\
\hline 2 EA & & 1.06 & 17 & 414 & 847 & 1,261 \\
\hline
\end{tabular}

MISC. ITEMS - SITEWORKUUTILITIES SUBTOTAL 
. WUESTINGHOUSE SAVANNAH RIVER COMPANY

PROJECTNO:

LINEITEM:

PROJECT NAME: ELECTOCHEMICAL DENITRATION \& CAUSTIC REC., PHASEI

LOCATION 1: S-AREA

PROJ. MANAGER D. HOBBS

ESTMATE TYPE: PRE-CONCEPTUAL

SITE WBS: SITE WBS
LOG NUMBER: 96-05-06, R/1

PAGE: 16

ESTIMATED BY: WNW/WLKJDM

OCATION 2: 730-1B/1080

DESIGN CLASSIFICATION: PS/C

TIME: 12:56:08

DATE 23-Aug-1996

FILE: NITRRECV.PWS

REPORT NAME: Detall Cost by WBS 9697 by seq

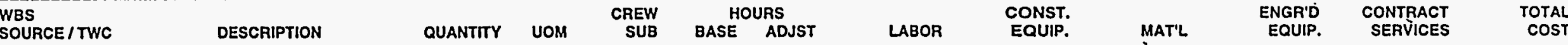

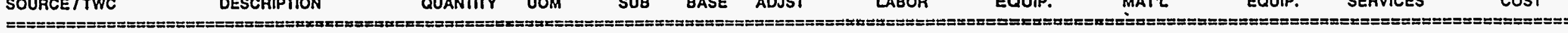

1.2 .2 .3

BEMCAP

BEMCAP FOR CIVIL / C/S/A WORK Momo:

BASED ON \& GTOTAL CIVIL

Unll Cost

0.000

0.000

N/A

10

10

TWC CODE:

MHRS.

37,407 MHAS

374,070

374,070

BEMCAP FOR ELECTRICALI

INSTRUMENTATION WORK

Momo:

8,944 MHRS

\begin{tabular}{cccc}
0.000 & 0.000 & N/A & 1 \\
\hline 1.00 & & & 8,944
\end{tabular}

1

ELECTRICALMHRS.

BEMCAP FOR MECHANICAL WORK

Memo:

Unit cost

$0.000 \quad 0.000$

N/A

10

29,588 MHRS

295,883

295,883

BASED ON \$ 1 TIOTAL.

BEMCAP SUBTOTAL

$x=x=z=x=2$

0

$\begin{aligned} & z=z=x x==2=:= \\ & \$ 678,897\end{aligned}$

$=x=x=s=x==x=0$

$== \pm==8=:=$

$\$ 678,897$

CONTRACT ADMIN. LCOST DISTR. LOTHEB

CONSTRUCTION CONTRACT

ADMINISTRATION $3.5 \%$ OF

CONTRACT COSTS

Unit Cost

$0.000 \quad 0.000$

N/A

46,053 DOLS

1.00

46,053

46,053

SUBCONTRACT COST DISTRIBUTION

- 2.5\% OF CONTRACT COST

Unit cost

$0.000 \quad 0.000$

N/A

32,895 DOLS

1.00

32,895

32,895

CONTRACT ADMIN/COST DISTR, / OTHER SUBTOTAL

$z= \pm=x=2 x=z=$

$\$ 78,948$

$\$ 78,948$ 
- Ẇ̇STINĞH̆OUSE SAVANNAH RIVER COMPANY

ENGINEERING \& CONSTRUCTION SERVICES DIVISION

LOQ NUMBER: 96-05-06, R/1

PROJECT NAME: ELECTOCHEMICAL DENITRATION \& CAUSTIC REC., PHASE I

LOCATION 1: S-AREA

PROS. MANAGER D. HOBBS

ESTMMATE TYPE: PRE-CONCEPTUAL

SITE PROJECT ESTIMATING

PAGE』 17

SITE WBS: SITE WBS

DETAIL LINE ITEM REPORT

ESTIMATED BY: WNW/WLKJDM

LOCATION 2. 730-1B/1080

DESIGN CLASSIFICATION: PS/C

TIME: 12:56:08

DATE 23-Aug-1996

FILE. NITRRECV.PWS

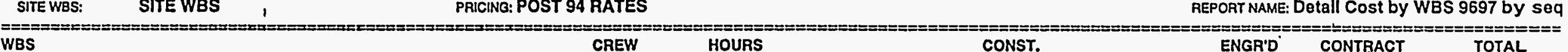

QUANTIT UOM SUB BASE ADJST

LABOR

CONST.

MAT'L

EQRTO

TOTAL

$1,2,3,9$

CRAET SUPPORT

TEMPORARY CONSTAUCTION $\bullet 7 \%$

OF DIRECT CONST. HRS.

TWC CODE: 9100

PROJECT SERVICES $\odot 6.5 \%$ OF

DIRECT CONST. MHRS

TWC CODE: 9200

MISC. CONSTRUCTION $\bullet 2.5 \%$ OF

DIRECT CONST. MHRS

TWC CODE: $\quad 9300$

CRAEI SUPPORT SUBTOTAL

$\begin{array}{llll}\text { Unlt Cost }{ }^{\circ} \text { SRSX29 } & 1.000 & 1.000 & 30.10\end{array}$

30

$\begin{array}{lllll}5,433 \text { HRS } & 1.00 & 5,433 & 163,547 & 163,547\end{array}$

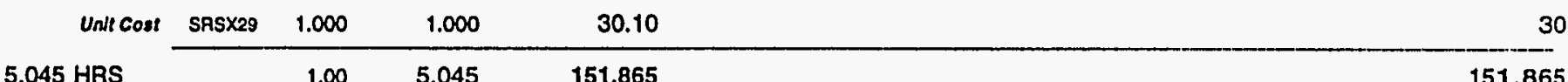

$\begin{array}{lllll}\text { Unll Cost } & \text { SASX29 } \quad 1.000 \quad 30.10 & 1.000 & 30.10 \quad 30\end{array}$

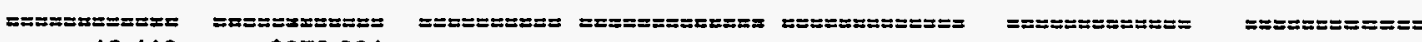

$12,419 \quad \$ 373,821 \quad \$ 373,82$

CONSTRUCTIONNONMANUAL

CONSTRUCTION NON-MANUAL $15 \%$ OF DIRECT CONSTRUCTION MHRS

Unil Cost

$\begin{array}{llll}\text { CNM } & 1.000 & 1.000 & 56.96\end{array}$ 57

TWC CODE:

SITE TECHNICAL REPRESENTATIVE (STA) $7 \%$ OF SUBCONTRACT

13,196 HRS

$\begin{array}{lll}1.00 & 13,196 \quad 751,617\end{array}$

751,617

\begin{tabular}{lrrrrr} 
Unit Cost & CNM & 1.000 & 1.000 & 56.96 & 57 \\
\cline { 2 - 5 } $1,617 \mathrm{HRS}$ & 1.00 & 1,617 & 92,106 & 92,106
\end{tabular}

TWC CODE: costs

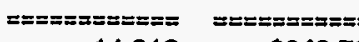

14,813

$\$ 843,723$

$\$ 843,7$

CONSTRUCTIONNONMANUAL,SUBTOTAL

PROJECT MANAGEMENT 
-

- WESTINGHOUSE saVANNAH RIVER CoMpany PROJECTNO.: UNE ITEM:

LOG NUMBER: 96-05-06, R/1

PROJECT NAME: ELECTOCHEMICAL DENITRATION \& CAUSTIC REC., PHASE I

LOCATION 1: S-AREA

PROJ. MANAGER D. HOBBS

ESTIMATE TYPE: PRE-CONCEPTUAL

SITE WBS: SITE WBS

SITE PROJECT ESTIMATING

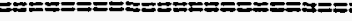

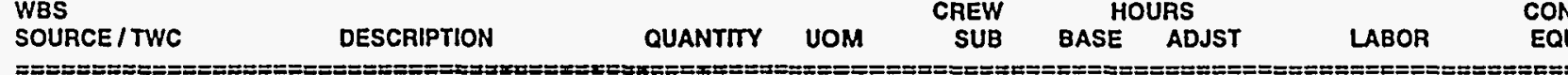

1.4 .1

PROJECT MANAGEMENT

\section{PRQJECT MANAGEMENT SUBTOTAL.}

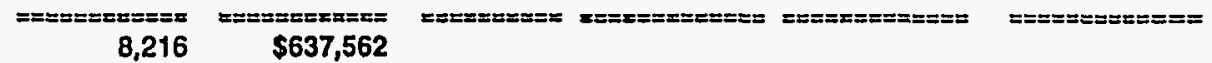

$8,216 \$ \$ 637,562$ $== \pm= \pm= \pm= \pm=$

PROJECT CONTROLSPM

PROJECT CONTROLS PM \&

ESTIMATING $-3 \%$ OF TEC LESS

PROJ. SUPPORT

Unst Cost

PCE 1.000

1.000

65.69

66

TWC CODE

RROJECT CONTROLSPM SUBTOTAL

4,562 MHRS

299,661

299,661

$\$ 299,661$

$4,562 \quad \$ 299,661$

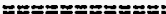

PROJECT CONTROLS DESIGN ENGINEERING

PROJECT CONTAOLS DE $1 \%$ OF TEC LESS PROJ. SUPPORT

Unit Cost

1,521 MHRS

PCE $1.000 \quad 1.000$

65.69

66

TWC CODE

\section{PROJECT CONTROLS DESIGNENGINEERING SUBTOTAL}

\begin{tabular}{|c|}
\hline 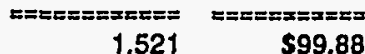 \\
\hline
\end{tabular}

$\$ 99,887$

PROJECT CONTROLS CONSTRUCTION

1.4 .4

PROJECT CONTROLS CONSTR. -

$7 \%$ OF CONSTRUCTION MHRS

Unit Cost

PCE $1.000, \quad 1.000$

65.69

66

NWC CODE:

$1.00 \quad 5,433 \quad 356,923$

356,923

PRQJECT CONTROLS CONSTRUCTION SUBTOTAL

$\begin{array}{rr}z=x=z=z= \pm z & z=z z=z==z== \\ 5,433 & \$ 356,923\end{array}$

$\$ 356,923$

$\$ 356,923$ 
6-05-06, $R$

PAGE \# 19

D. HOBBS

PRE-CONCEPTUAL

DETAIL LINE ITEM REPORT

ESTIMATED BY: WNWNLLKDM

LOCATON 2: 730-1B/1080

$\begin{array}{ll}\text { ESTIMATE TYPE: } & \text { PRE-CONCE } \\ \text { SITE WBS: } & \text { SITE WBS }\end{array}$

DESIGN CLASSIFICATION: PSIC

TIME: 12:56:08

DATE 23-Aug-1996

FILE: NITRRECV.PWS

PRICING: POST 94 RATES

PRICING: POST 94 RATES

REPORT NAME: Detall Cost by WBS 9697 by seq

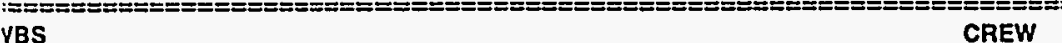

OOUACE/TWC DESCRIPTION QUANTITY UOM SUB

HOUAS
HASE

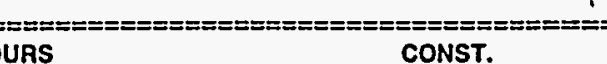

= $============================$

PROJECT SUBTOTAL
PROJECT ESCALATION

SUBTOTAL COST INCLUDING ESCALATION

\begin{tabular}{|c|c|c|c|c|c|c|}
\hline 156,403 & $\begin{array}{r}\$ 7,195,146 \\
\$ 565,199\end{array}$ & $\begin{array}{r}\$ 678,897 \\
\$ 65,853\end{array}$ & $\begin{array}{r}\$ 1,910,462 \\
\$ 185,315\end{array}$ & $\begin{array}{r}\$ 2,175,000 \\
\$ 210,975\end{array}$ & $\begin{array}{r}\$ 1,394,748 \\
\$ 135,291\end{array}$ & $\begin{array}{r}\$ 13,354,253 \\
\$ 1,162,632\end{array}$ \\
\hline 156,403 & $\$ 7,760,344$ & $\$ 744,750$ & $\$ 2,095,777$ & $\$ 2,385,975$ & $\$ 1,530,039$ & $\$ 14,516,885$ \\
\hline
\end{tabular}

\begin{abstract}
FY 97 G \& A RATE
SUBTOTAL INCLUDING ESCALATION
\end{abstract}

MANAGEMENT RESERVE $\circledast 0.00 \%$

CONTINGENCY $\odot \quad 0.00 \%$ $\begin{array}{llllll}\$ 1,707,276 & \$ 163,845 & \$ 461,071 & . & \$ 524,915 & \$ 336,608\end{array}$

156,403

$\$ 9,467,620$

$\$ 908,595$

$\$ 2,556,847$

$\$ 2,910,890$

$\$ 1,866,647$

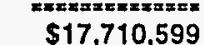

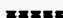

$\$ 5,313,000$

\$o 